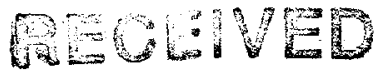 \\ OCT 16 2ust \\ OSTI \\ Energy Savings Calculations for Heat Island Reduction Strategies in Baton Rouge, Sacramento and Salt Lake City
}

LBNL-42890

\author{
S. Konopacki and H. Akbari \\ Heat Island Group \\ Environmental Energy Technologies Division \\ Lawrence Berkeley National Laboratory \\ University of California \\ Berkeley, CA 94720
}

March 2000

This work was supported by the US Environmental Protection Agency (EPA) and the Assistant Secretary for Energy Efficiency and Renewable Energy, Building Technologies, of the US Department of Energy (DOE) under contract No. DE-AC03-76SF00098. 
89 mexdel paper 


\section{DISCLAIMER}

This report was prepared as an account of work sponsored by an agency of the United States Government. Neither the United States Government nor any agency thereof, nor any of their employees, make any warranty, express or implied, or assumes any legal liability or responsibility for the accuracy, completeness, or usefulness of any information, apparatus, product, or process disclosed, or represents that its use would not infringe privately owned rights. Reference herein to any specific commercial product, process, or service by trade name, trademark, manufacturer, or otherwise does not necessarily constitute or imply its endorsement, recommendation, or favoring by the United States Government or any agency thereof. The views and opinions of authors expressed herein do not necessarily state or reflect those of the United States Government or any agency thereof. 


\section{DISCLAIMER}

Portions of this document may be illegible in electronic image products. Images are produced from the best available original document. 


\section{Acknowledgement}

This work was supported by the US Environmental Protection Agency (EPA) and the Assistant Secretary for Energy Efficiency. and Renewable Energy, Building Technologies, of the US Department of Energy (DOE) under contract No. DE-AC03-76SF00098. The authors would like to thank Dariush Arasteh, Paul Berdahl, Mel Pomerantz (LBNL) and Virginia Gorsevsky (EPA) for their pre-publication reviews of this report and Brian Pon (LBNL) for producing the graphics. 


\title{
Energy Savings Calculations for Heat Island Reduction Strategies in Baton Rouge, Sacramento and Salt Lake City
}

\author{
S. Konopacki and H. Akbari \\ Heat Island Group \\ Environmental Energy Technologies Division \\ Lawrence Berkeley National Laboratory
}

\begin{abstract}
In 1997, the US Environmental Protection Agency (EPA) established the "Heat Island Reduction Initiative", to quantify the potential benefits of Heat Island Reduction (HIR) strategies (i.e., shade trees, reflective roofs, reflective pavements and urban vegetation) to reduce cooling energy use in buildings, lower the ambient air temperature and improve urban air quality in cities, and reduce $\mathrm{CO}_{2}$ emissions from power plants. Under this initiative, the Urban Heat Island Pilot Project (UHIPP) was created with the objective to investigate the potential of HIR strategies in residential and commercial buildings in three initial UHIPP cities: Baton Rouge, Sacramento and Salt Lake City.

This paper summarizes our efforts to calculate the annual energy savings, peak power avoidance and annual $\mathrm{CO}_{2}$ reduction of HIR strategies in the three initial cities. In this analysis, we focused on three building types that offer most savings potential: single-family residence, office and retail store. Each building type was characterized in detail by old or new construction and with a gas furnace or an electric heat pump. We defined prototypical building characteristics for each building type and simulated the impact of HIR strategies on building cooling and heating energy use and peak power demand using the DOE-2.1E model. Our simulations included the impact of (1) strategically-placed shade trees near buildings [direct effect], (2) use of high-albedo roofing material on building [direct effect], (3) combined strategies 1 and 2 [direct effect], (4) urban reforestation with high-albedo pavements and building surfaces [indirect effect] and (5) combined strategies 1,2 and 4 [direct and indirect effects]. We then estimated the total roof area of air-conditioned buildings in each city using readily obtainable data to calculate the metropolitan-wide impact of HIR strategies.

The results show, that in Baton Rouge, potential annual energy savings of $\$ 15 \mathrm{M}$ could be realized by rate-payers from the combined direct and indirect effects of HIR strategies. Additionally, peak power avoidance is estimated at $133 \mathrm{MW}$ and the reduction in annual carbon emissions at $41 \mathrm{kt}$. In Sacramento, the potential annual energy savings is estimated at $\$ 26 \mathrm{M}$, with an avoidance of $486 \mathrm{MW}$ in peak power and a reduction in annual carbon of $92 \mathrm{kt}$. In Salt Lake City, the potential annual energy savings is estimated at $\$ 4 \mathrm{M}$, with an avoidance of $85 \mathrm{MW}$ in peak power and a reduction in annual carbon of $20 \mathrm{kt}$.
\end{abstract}




\section{Executive Summary}

In 1997, the US Environmental Protection Agency (EPA) embarked on an initiative to quantify the potential benefits of Heat Island Reduction (HIR) strategies (i.e., shade trees, reflective roofs, reflective pavements and urban vegetation) to reduce cooling energy use in buildings, lower the ambient air temperature and improve urban air quality in cities, and reduce $\mathrm{CO}_{2}$ emissions from power plants. Under this initiative, entitled "The Heat Island Reduction Initiative", EPA has been engaged in two major projects. The first is the Urban Heat Island Pilot Project (UHIPP) and the second is the Energy Star ${ }^{\circledR}$ Roof Products Program, which is a joint effort with the US Department of Energy (DOE).

\section{Project Objectives}

The objective of UHIPP is to investigate the use of HIR strategies to reduce cooling energy use in buildings and to reduce the ambient air temperature. Cooling of the ambient air temperature has the additional benefit of reducing urban smog concentration, and hence, improving urban air quality. Baton Rouge, LA, Sacramento, CA and Salt Lake City, UT were selected for UHIPP. Since the inception of the project, Lawrence Berkeley National Laboratory (LBNL) has conducted detailed studies to investigate the impact of HIR strategies on heating and cooling energy use of the three selected pilot cities. In addition, LBNL has collected urban surface characteristic data and conducted preliminary meteorology and urban smog simulations for the three pilot cities.

This report summarizes our efforts to calculate the annual energy savings, peak power avoidance and annual $\mathrm{CO}_{2}$ reduction of HIR strategies in Baton Rouge, Sacramento and Salt Lake City. In this analysis, we focused on three major building types that offer most savings potential $^{1}$ : residence, office and retail store.

\section{Methodology}

A methodology was developed that incorporates readily obtainable data from building energy simulations, previous heat island studies and the US Census to estimate the potential metropolitan-wide benefits of HIR strategies. The methodology consists of five parts:

1. define prototypical building characteristics in detail for old and new construction,

2. simulate annual energy use and peak power demand using the DOE-2.1E model,

3. determine direct and indirect energy savings from each HIR strategy,

4. identify the total roof area of air-conditioned buildings in each city, and

5. calculate the metropolitan-wide impact of HIR strategies.

1 These building types were selected based on an earlier detailed study of the direct energy savings potential of high-reflective roofs in eleven US metropolitan areas, in which they were determined to account for over $90 \%$ of the national energy savings (Konopacki et al. 1997). 
The building energy simulations are performed for a base case and five modified cases. The modified simulations include the impact of the following HIR strategies:

1. strategically-placed shade trees near building [direct effect]

2. use of high-albedo roofing material on building [direct effect]

3. combined strategies 1 and 2 [direct effect]

4. urban reforestation with high-reflective pavements and building surfaces [indirect effect]

5. combined strategies 1,2 and 4 [direct and indirect effects].

\section{Results}

The potential metropolitan-wide benefits of HIR strategies from the total of residential, office and retail buildings with air-conditioning are presented in Table EX.1 and Figures EX.1,2,3. The estimates are in the forms of annual energy savings, annual electricity savings, annual natural gas deficit, peak power avoided and annual carbon reduction. Note, the following points should be considered when examining the results.

- Base energy expenditures and peak power demand are calculated for buildings without shade trees and with a dark roof (albedo 0.2), and direct savings are determined for buildings with 8 shade trees (retail 4) and a high-albedo roof (residential 0.5 and commercial $0.6)$.

- Combined HIR effects are not precisely the sum of individual effects.

- The conversion from BWh to carbon is for the US mix of electricity, in 1995, DOE/EIA0383(97) (EIA 1997) shows that $3000 \mathrm{BkWh}$ sold emitted 500MtC (million metric tons of carbon), thus $1 \mathrm{BWh}$ emits $0.167 \mathrm{ktC}$.

Baton Rouge is a metropolitan area of over 0.5 million persons and is situated inland, in southeastern Louisiana, where the climate is hot and humid with an April through October cooling season. Most residential buildings are one story and commercial buildings are low-rises. The saturation of air conditioning is high in both residential and commercial buildings. The total roof area of residential, office and retail buildings with air-conditioning is $245 \mathrm{Mft}^{2}, 13$ and 18 , respectively. Annual electricity savings of $\$ 18 \mathrm{M}$ less a $17 \%$ natural gas deficit combine for a potential rate-payer benefit of $\$ 15 \mathrm{M}$ (79\% residence, $6 \%$ office and $15 \%$ retail) in total annual energy savings from the combined direct and indirect (15\%) effects of HIR strategies. Additionally, peak power avoidance is estimated at $133 \mathrm{MW}(89 \%, 4 \%$ and $7 \%)$ and the reduction in annual carbon emissions at $41 \mathrm{kt}(82 \%, 5 \%$ and $13 \%)$.

Sacramento is a metropolitan area of almost 1.5 million persons and is situated inland, in the central valley of northern California, where the climate is hot and dry with a cooling season lasting from May through September. Most residential buildings are one story and commercial buildings are low-rises. The saturation of air conditioning is high in both residential and commercial buildings. The total roof area of residential, office and retail buildings with airconditioning is $648 \mathrm{Mft}^{2}, 37$ and 50 , respectively. Annual electricity savings of $\$ 46 \mathrm{M}$ less a $43 \%$ natural gas deficit combine for a potential rate-payer benefit of $\$ 26 \mathrm{M}(51 \%$ residence, $17 \%$ office and $32 \%$ retail) in total annual energy savings from the combined direct and indirect (23\%) effects of HIR strategies. Additionally, peak power avoidance is estimated at $486 \mathrm{MW}$ $(84 \%, 7 \%$ and $9 \%)$ and the reduction in annual carbon at $92 \mathrm{kt}(72 \%, 10 \%$ and $18 \%)$. 
Salt Lake City is a metropolitan area of nearly 1.1 million persons and is situated inland, in the high-desert terrain of northwestern Utah, where the climate is hot and dry during the June through September cooling season, and cold with a long heating season beginning in September and ending in May. Most residential buildings are one story and commercial buildings are lowrises. The saturation of air conditioning is high in both residential (except in the older residences) and commercial buildings. The total roof area of residential, office and retail buildings with air-conditioning is $120 \mathrm{Mft}^{2}, 15$ and 21 , respectively. Annual electricity savings of $\$ 7 \mathrm{M}$ less a $51 \%$ natural gas deficit combine for a potential rate-payer benefit of $\$ 4 \mathrm{M}(11 \%$ residence, $31 \%$ office and $58 \%$ retail) in total annual energy savings from the combined direct and indirect $(22 \%)$ effects of HIR strategies. Additionally, peak power avoidance is estimated at $85 \mathrm{MW}(65 \%, 17 \%$ and $18 \%)$ and the reduction in annual carbon at $20 \mathrm{kt}(49 \%, 18 \%$ and $33 \%)$.

Savings from the indirect impact (cooler ambient air temperature) of HIR strategies were $15 \%, 23 \%$ and $22 \%$ of the overall savings for Baton Rouge, Sacramento and Salt Lake City. Our climate simulations indicated a reduction in maximum air temperature of $2^{\circ} \mathrm{F}, 3^{\circ} \mathrm{F}$ and $3^{\circ} \mathrm{F}$, for these cities (Taha 1999b). The indirect savings are a function of local climate and the degree of surface modification possible. For instance, the cooling seasons for Sacramento and Salt Lake City are fairly short, and the potential for ambient cooling by urban vegetation in Baton Rouge is limited because of it's humid climate. Based on this analysis, we anticipate that for most other major US cities, the indirect impact would be in the same range of $15 \%$ to $25 \%$. However, for a very hot and dry climate such as Phoenix (with a long cooling season which can also benefit from all HIR strategies) the indirect potential of a full-scale implementation of HIR strategies may even be larger.

\section{Discussion}

Since, roofs and shade trees offer the direct saving potential, from an energy-saving point of view, programs that focus on reflective roofs and shade trees should have highest priority. However, when considering smog and air-quality issues, programs that focus on reflective surfaces (roofs and pavements) that can cool the ambient air in both humid and dry climate conditions should have priority.

In the next phase of this project, we will perform a similar analysis for two additional UHIPP cities: Chicago and Houston. Using results from the five UHIPP cities and additional analysis for several other cities we will develop a database to extrapolate savings across the US. 
Table EX.1. Metropolitan-wide estimates of annual energy savings, peak power avoided and annual carbon reduction from Heat Island Reduction (HIR) strategies for residential and commercial buildings in Baton Rouge, Sacramento and Salt Lake City. Direct savings are from the strategic placement of shade trees and the use of high-albedo roofs on individual buildings, and indirect savings include the impact of reduced air temperature from urban reforestation and high-albedo surfaces.

\begin{tabular}{|c|c|c|c|c|c|c|c|}
\hline $\begin{array}{c}\text { metropolitan area } \\
\& \\
\text { HIR } \\
\text { strategy }\end{array}$ & $\begin{array}{c}\text { annual } \\
\text { energy } \\
\text { savings } \\
{[\mathrm{M} \$]}\end{array}$ & \multicolumn{2}{|c|}{$\begin{array}{l}\text { annual } \\
\text { electricity } \\
\text { savings }\end{array}$} & \multicolumn{2}{|c|}{$\begin{array}{c}\text { annual } \\
\text { natural gas } \\
\text { deficit }\end{array}$} & $\begin{array}{c}\text { peak } \\
\text { power } \\
\text { avoided } \\
\text { [MW] }\end{array}$ & $\begin{array}{c}\text { annual } \\
\text { carbon } \\
\text { reduction } \\
{[\mathrm{kt}]}\end{array}$ \\
\hline Baton Rouge & & & & & & & \\
\hline base case & 114.8 & 1275 & 92.8 & 30.7 & 21.9 & 858 & 213 \\
\hline direct shade tree & 5.2 & 94 & 6.9 & 2.4 & 1.7 & 62 & 16 \\
\hline direct high albedo & 8.0 & 120 & 8.7 & 1.0 & 0.7 & 60 & 20 \\
\hline direct combined & 12.9 & 210 & 15.3 & 3.4 & 2.4 & 120 & 35 \\
\hline indirect & 2.3 & 39 & 2.8 & 0.7 & 0.5 & 13 & 6 \\
\hline direct \& indirect & 15.0 & 248 & 18.1 & 4.3 & 3.1 & 133 & 41 \\
\hline \multicolumn{8}{|l|}{ Sacramento } \\
\hline base case & 296.2 & 2238 & 185.9 & 162.2 & 110.3 & 2454 & 374 \\
\hline direct shade tree & 9.8 & 247 & 20.6 & 15.8 & 10.7 & 180 & 41 \\
\hline direct high albedo & 14.6 & 220 & 18.3 & 5.5 & 3.8 & 163 & 37 \\
\hline direct combined & 23.5 & 464 & 38.6 & 22.1 & 15.1 & 371 & 78 \\
\hline indirect & 5.9 & 114 & 9.5 & 5.3 & . 3.6 & 106 & 19 \\
\hline direct $\&$ indirect & 26.1 & 554 & 46.1 & 29.4 & 20.0 & 486 & 92 \\
\hline \multicolumn{8}{|l|}{ Salt Lake City } \\
\hline base case & 67.0 & 511 & 31.4 & 70.8 & 35.6 & 488 & 85 \\
\hline direct shade tree & 1.1 & 52 & 3.3 & 4.2 & 2.2 & 33 & 9 \\
\hline direct high albedo & 1.8 & 45 & 2.8 & 2.0 & 1.0 & 32 & 8 \\
\hline direct combined & 2.9 & 94 & 5.9 & 5.9 & 3.0 & 65 & 16 \\
\hline indirect & 0.8 & 25 & 1.6 & 1.6 & 0.8 & 20 & 4 \\
\hline direct $\&$ indirect & 3.6 & 116 & 7.3 & 7.3 & 3.7 & 85 & 20 \\
\hline
\end{tabular}

Metropolitan-wide annual energy savings $[\mathrm{M} \$=\mathrm{Million} \$]$, annual electricity savings $[\mathrm{M} \$ \& \mathrm{BWh}=$ BillionWatt-hour], annual natural gas deficit $[\mathrm{M} \$ \&$ Mth $=$ Million therms], peak power avoided $[\mathrm{MW}=$ MegaWatt] and annual carbon reduction [kt $=$ thousand tons].

b The methodology consisted of the following: [1] define prototypical building characteristics in detail for old and new construction, [2] simulate annual energy use and peak power demand using the DOE-2.1E model, [3] determine direct and indirect energy benefits from high-albedo surfaces (roofs and pavements) and trees, [4] identify the total roof area of air-conditioned buildings in each city, and [5] calculate the metropolitan-wide impact of HIR strategies.

c Base energy expenditures and peak power demand are calculated for buildings without shade trees and with a dark roof (albedo 0.2). Direct savings are determined for buildings with 8 shade trees (retail 4) and a highalbedo roof (residential 0.5 and commercial 0.6 ).

d Combined HIR effects are not precisely the sum of individual effects.

e The conversion from BWh to carbon is for the US mix of electricity. In 1995, DOE/EIA-0383(97) (EIA 1997) shows that $3000 \mathrm{BkWh}$ sold emitted $500 \mathrm{MtC}$ (million metric tons of carbon), thus $1 \mathrm{BWh}$ emits 0.167 $\mathrm{ktC}$. 

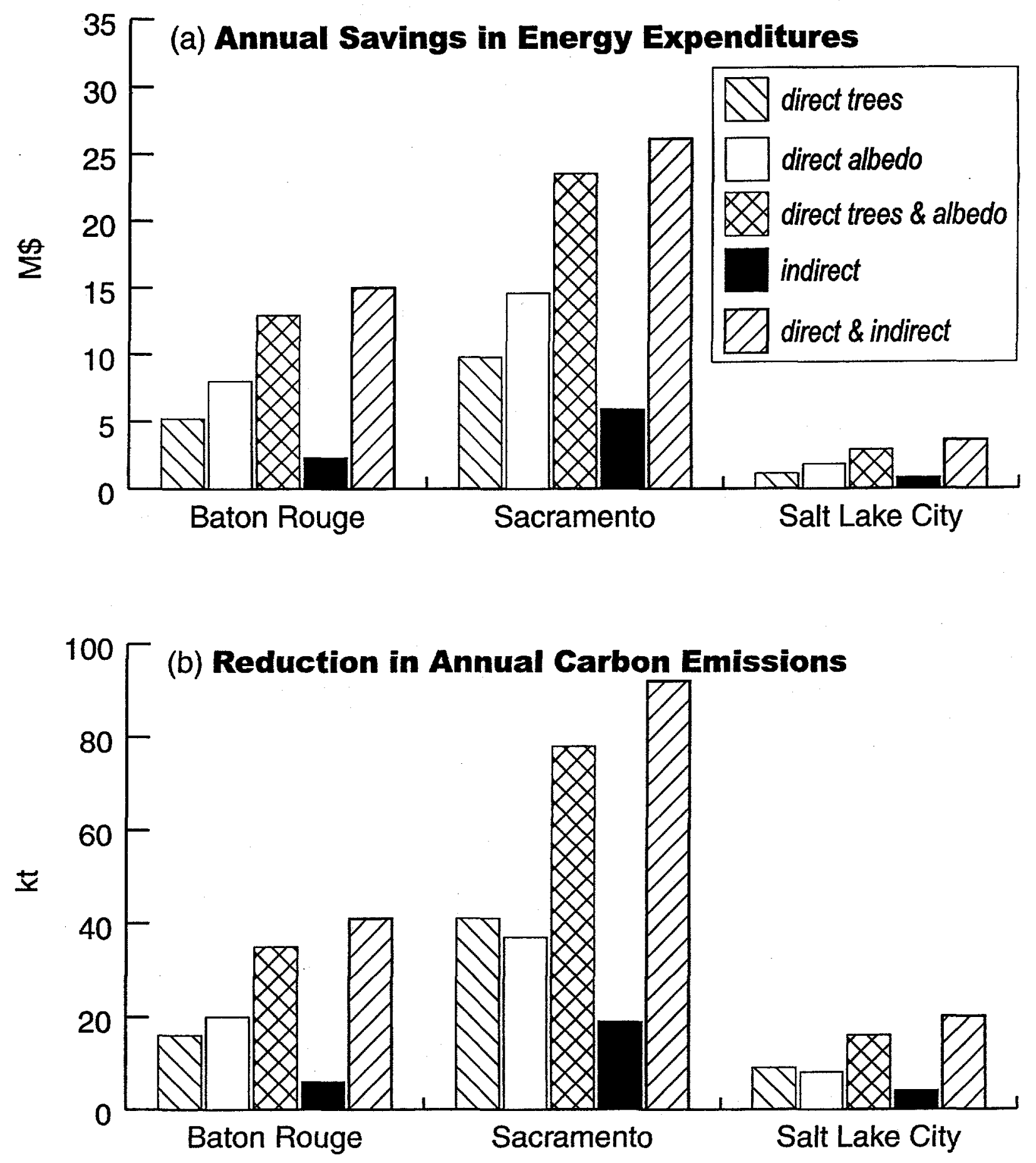

Figure EX.1. (a) Savings in annual energy expenditures and (b) reduction in annual carbon emissions. Estimates are for (i) direct effect of shade trees, (ii) direct effect of increasing roof albedo, (iii $=\mathrm{i}+\mathrm{ii}$ ) combined direct effect, (iv) indirect effect of increasing urban vegetation and albedo of roofs and pavements, and ( $\mathrm{v}=\mathrm{iii}+\mathrm{iv})$ combined direct and indirect effect of urban vegetation, roofs, and pavements. Note that combined effects are geometic addition of individual effects. 

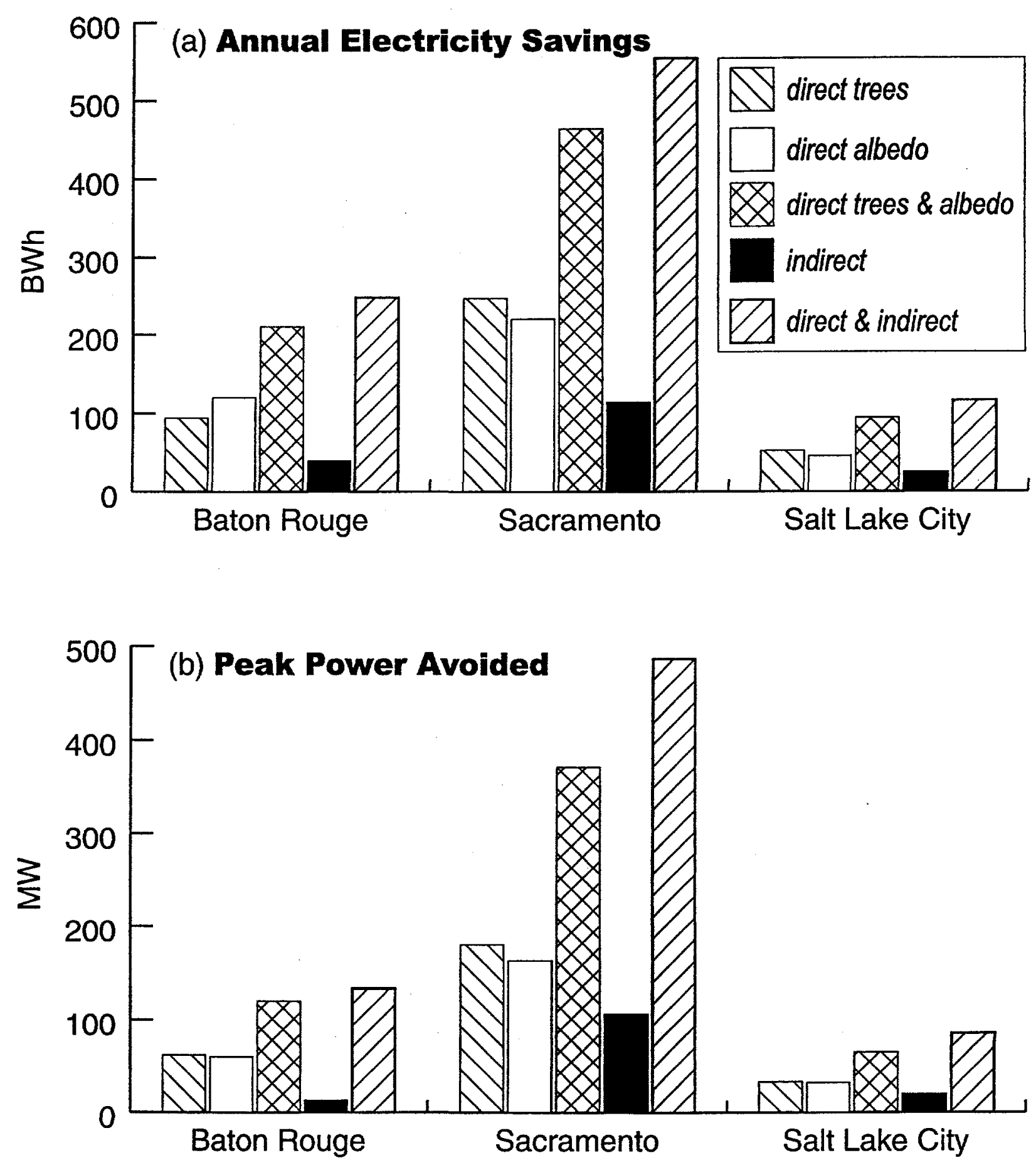

Figure EX.2. (a) Savings in annual electricity and (b) peak power avoided. Estimates are for (i) direct effect of shade trees, (ii) direct effect of increasing roof albedo, (iii $=i+$ ii) combined direct effect, (iv) indirect effect of increasing urban vegetation and albedo of roofs and pavements, and $(\mathrm{v}=$ iii + iv) combined direct and indirect effect of urban vegetation, roofs, and pavements. Note that combined effects are geometic addition of individual effects. 

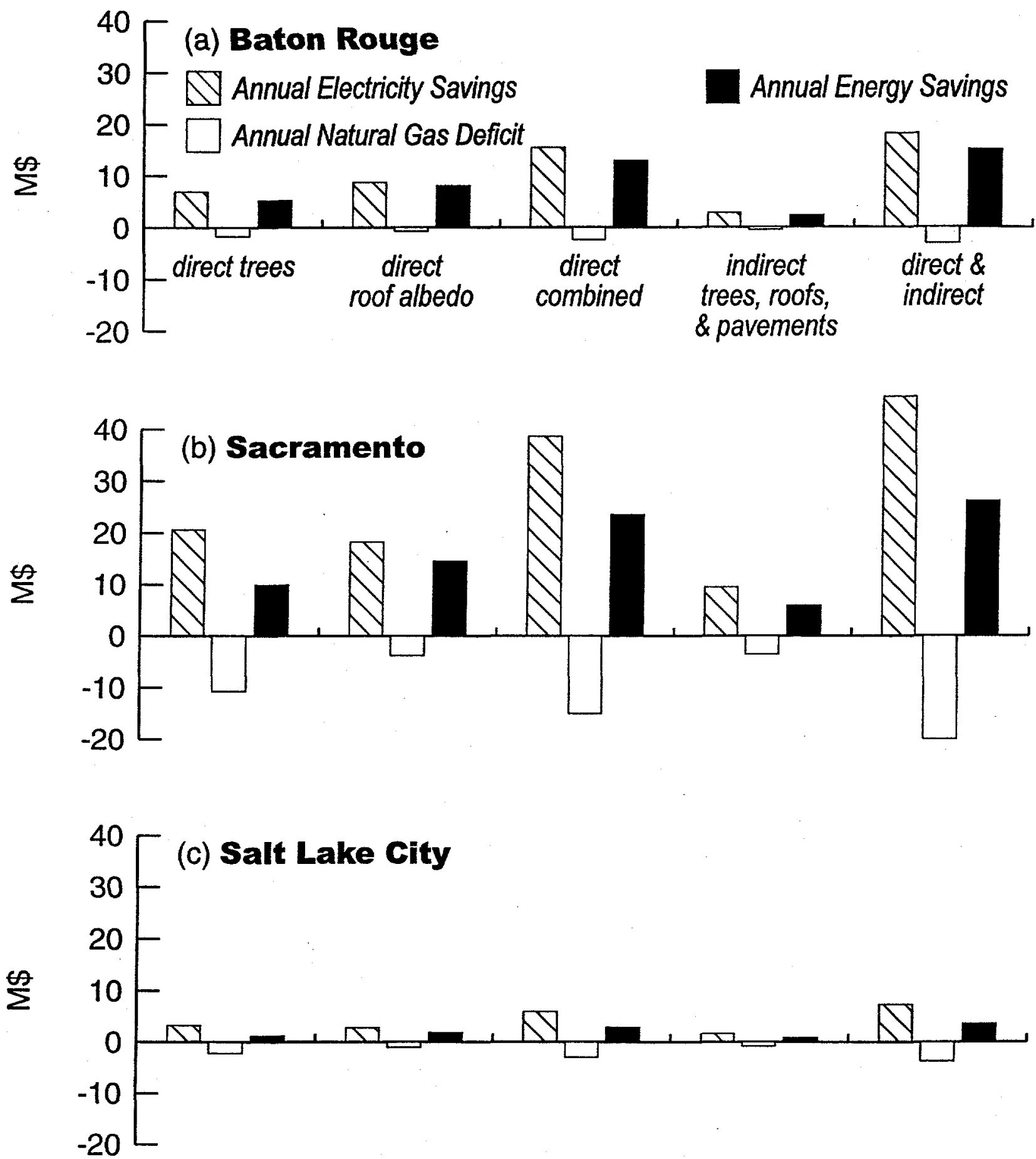

Figure EX.3. Annual electricity savings, natural gas deficit, and resulting energy savings for (a) Baton Rouge, (b) Sacramento, and (c) Salt Lake City. Estimates are for (i) direct effect of shade trees, (ii) direct effect of increasing roof albedo, (iii $=\mathrm{i}+\mathrm{ii}$ ) combined direct effect, (iv) indirect effect of increasing urban vegetation and albedo of roofs and pavements, and $(\mathrm{v}=\mathrm{iii}+\mathrm{iv})$ combined direct and indirect effect of urban vegetation, roofs, and pavements. Note that combined effects are geometic addition of individual effects. 


\section{Table of Contents}

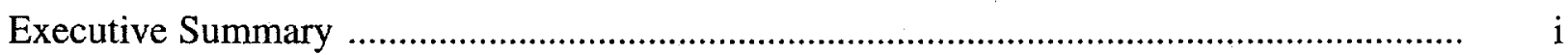

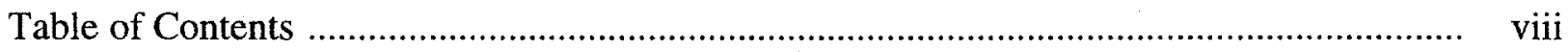

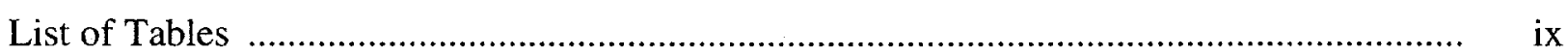

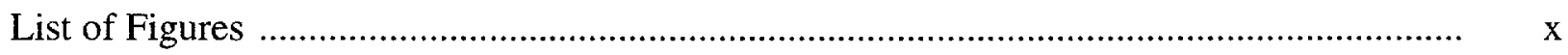

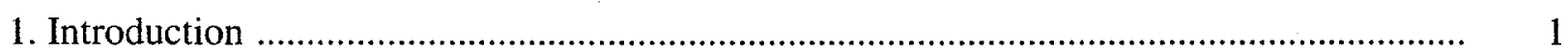

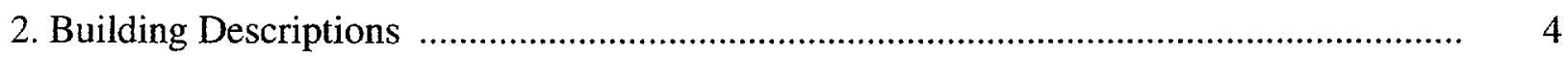

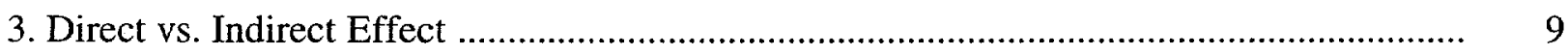

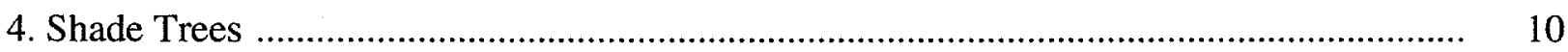

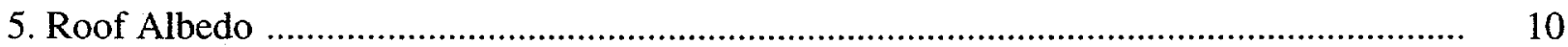

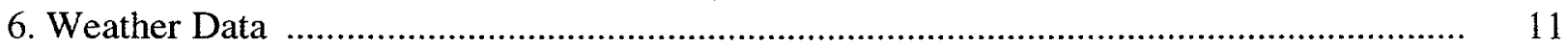

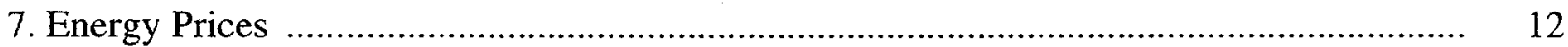

8. Simulated Energy Use \& Savings and Peak Power Demand \& Savings ........................ 13

9. Calculation of Air-Conditioned Roof Area ............................................................. 21

10. Metropolitan-Wide Impact of Heat Island Reduction Strategies ................................ 24

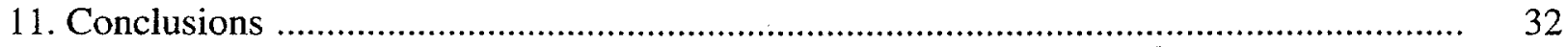

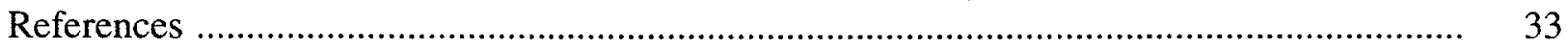

Appendix A. Simulated Energy Use \& Savings and Peak Power Demand \& Savings ......... 35 


\section{List of Tables}

Table

Description

Page

Table EX.1. Metropolitan-wide estimates of annual energy savings, peak power avoided and annual carbon reduction from Heat Island Reduction strategies. iv

Table 1.1. Metropolitan-wide estimates of direct energy savings, avoided peak power and carbon reduction from the use of high-albedo roofs for residential and commercial buildings in eleven Metropolitan Statistical Areas

Table 2.1. Residence prototypical construction, equipment, and interior load characteristics.

Table 2.2. Office prototypical construction, equipment, and interior load characteristics.

Table 2.3. Retail Store prototypical construction, equipment, and interior load characteristics.

Table 5.1. Roof materials and weathered albedo for residential and commercial buildings.

Table 6.1. Maximum air temperature and degree-hour data for standard TMY2 weather and modified.

Table 7.1. Average 1997 prices of electricity and natural gas for residential and commercial sectors.

Table 8.1(a). Baton Rouge simulated cooling and heating annual base energy expenditures and savings $\left[\$ / 1000 \mathrm{ft}^{2}\right]$, and peak power demand and savings $\left[\mathrm{kW} / 1000 \mathrm{ft}^{2}\right]$ from Heat Island Reduction strategies.

Table 8.1(b). Baton Rouge simulated cooling and heating annual base energy expenditures [ $\left.\$ / 1000 \mathrm{ft}^{2}\right]$ and savings [\%], and peak power demand [kW/1000 $\left.\mathrm{ft}^{2}\right]$ and savings [\%] from Heat Island Reduction strategies

Table 8.2(a). Sacramento simulated cooling and heating annual base energy expenditures and savings [\$/1000ft ${ }^{2}$, and peak power demand and savings $\left[\mathrm{kW} / 1000 \mathrm{ft}^{2}\right]$ from Heat Island Reduction strategies.

Table 8.2(b). Sacramento simulated cooling and heating annual base energy expenditures $\left[\$ / 1000 \mathrm{ft}^{2}\right]$ and savings [\%], and peak power demand $\left[\mathrm{kW} / 1000 \mathrm{ft}^{2}\right]$ and savings [\%] from Heat Island Reduction strategies

Table 8.3(a). Salt Lake City simulated cooling and heating annual base energy expenditures and savings $\left[\$ / 1000 \mathrm{ft}^{2}\right]$, and peak power demand and savings $\left[\mathrm{kW} / 1000 \mathrm{ft}^{2}\right]$ from Heat Island Reduction strategies.

Table 8.3(b). Salt Lake City simulated cooling and heating annual base energy expenditures [ $\left.\$ / 1000 \mathrm{ft}^{2}\right]$ and savings [\%], and peak power demand $\left[\mathrm{kW} / 1000 \mathrm{ft}^{2}\right]$ and savings $[\%]$ from Heat Island Reduction strategies. 


\section{List of Tables (continued)}

Table

Description

Table 9.1. Calculation of air-conditioned roof area for residential and commercial buildings.

Table 9.2. Estimates of commercial and residential building roof area.

Table 10.1(a). Baton Rouge metropolitan-wide estimates of annual base energy expenditures and savings, and peak power demand and savings.

Table 10.1(b). Baton Rouge metropolitan-wide estimates of annual energy savings, peak power avoided and annual carbon reduction.

Table 10.2(a). Sacramento metropolitan-wide estimates of annual base energy expenditures and savings, and peak power demand and savings.

Table 10.2(b). Sacramento metropolitan-wide estimates of annual energy savings, peak power avoided and annual carbon reduction.

Table 10.3(a). Salt Lake City metropolitan-wide estimates of annual base energy expenditures and savings, and peak power demand and savings.

Table 10.3(b). Salt Lake City metropolitan-wide estimates of annual energy savings, peak power avoided and annual carbon reduction.

\section{List of Figures}

Figure

Description

Figure EX.1. Metropolitan-wide estimates of savings in annual energy expenditures and reduction in annual carbon emissions.

Figure EX.2. Metropolitan-wide estimates of savings in annual electricity and peak power avoided.

Figure EX.3. Metropolitan-wide estimates of annual electricity savings, natural gas deficit and total energy savings. 


\section{Introduction}

Urban areas tend to have higher air temperatures than their rural surroundings, as a result of gradual surface modifications that include replacing the natural vegetation with buildings and roads. The term "Urban Heat Island" describes this phenomenon. The surfaces of buildings and pavements absorb solar radiation and become extremely hot, which in turn warms the surrounding air. Cities that have been "paved over" do not receive the benefit from the natural cooling effect of vegetation ${ }^{2}$. As the air temperature rises, so does the demand for air-conditioning $(\mathrm{a} / \mathrm{c})$. This leads to higher emissions by power plants, as well as increased smog formation due to warmer temperature. Strategies to reverse the heat island effect include planting shade trees and other vegetation and incorporating high-albedo ${ }^{3}$ roofs and pavements into the urban landscape.

\section{Previous Studies}

Several field studies have documented measured energy savings that result from the placement of shade trees around buildings and increased roof albedo. In two monitored houses in Sacramento, Akbari et al. (1997b) have demonstrated that seasonal cooling energy savings of $30 \%$ and peak power savings of $35 \%$ can be realized with the placement of shade trees near the buildings. Akbari et al. (1997a) has shown in one monitored Sacramento house seasonal cooling energy savings of $63 \%$ and peak power savings of $25 \%$, and in two identical Sacramento school bungalows cooling energy savings of $46 \%$ and peak power savings of $20 \%$ from an increased roof albedo. A recent project was completed that monitored the energy-saving impact of highreflective roofs in three California commercial buildings (Konopacki et al. 1998c) and eleven Florida residences (Parker et al. 1998). The commercial buildings saved up to $18 \%$ in seasonal electricity use and the residences saved an average of 19\%. Parker et al. (1997) have monitored seven retail stores within a strip mall in Florida before and after applying a high-albedo coating to the roof and measured a $25 \%$ drop in seasonal cooling energy use. Hildebrandt et al. (1998) observed daily a/c savings of 17,26 , and $39 \%$ in an office, museum and hospice with highalbedo roofs in Sacramento. Akridge (1998) reported savings of $28 \%$ for an education building which had an unpainted galvanized roof coated with white acrylic. An office building in southern Mississippi was shown to save $22 \%$ after the application of a high-reflective coating (Boutwell and Salinas 1986).

In addition to field studies, computer simulations of cooling energy savings from an increased roof albedo have been documented in residential and commercial buildings in many studies which include: Konopacki and Akbari (1998a), Akbari et al. (1998), Parker et al. (1998) and Gartland et al. (1996). Additionally, Taha et al. (1996) have modeled the impact of shade trees and their impact on air temperature. In a detailed study sponsored by the EPA, we estimated the direct energy savings potential from high-albedo roofs in eleven US metropolitan areas (Konopacki et al. 1997). The results showed that three major building types account for over $90 \%$ of the annual electricity and monetary savings: old residences $(55 \%)$, new residences (15\%), and old/new office buildings and retail stores together $(25 \%)$. Furthermore, these three building types account for $93 \%$ of the total air-conditioned roof area. The regional savings were a function of energy savings in the air-conditioned building, stock of residential and commercial

\footnotetext{
2 Evaporation of liquid water occurs at the leaf surface and lowers the local air temperature.

3 When sunlight hits a surface some energy is reflected (albedo $=a$ ) and the remainder is absorbed $(\alpha=1-a)$. High-a surfaces become cooler than low-a surfaces and consequently lower the cooling load of a building.
} 
buildings, percentage of buildings that were air-conditioned, and the number of floors per building (roof area). Populous cities with an older low-rise building stock, in hot and sunny climates, and with a high level of a/c saturation provided the highest savings potential for heat island reduction strategies. Metropolitan-wide savings were as much as $\$ 37 \mathrm{M}$ for Phoenix and $\$ 35 \mathrm{M}$ in Los Angeles and as low as $\$ 3 \mathrm{M}$ in the heating-dominated climate of Philadelphia. Table 1.1 summarizes metropolitan-wide estimates of total residential and commercial direct annual energy and electricity savings, annual gas deficit, avoided peak power and annual carbon reduction for the eleven cities.

\section{Project Objectives}

In 1997, the US Environmental Protection Agency (EPA) embarked on an initiative to quantify the potential benefits of Heat Island Reduction (HIR) strategies (i.e., shade trees, reflective roofs, reflective pavements and urban vegetation) to reduce cooling energy use in cities, improve urban air quality and reduce $\mathrm{CO}_{2}$ emissions from power plants. Under this initiative, entitled "The Heat Island Reduction Initiative", EPA has been engaged in two major projects. The first is the Urban Heat Island Pilot Project (UHIPP) and the second is the Energy Star ${ }^{\circledR}$ Roof Products Program, which is a joint effort with the US Department of Energy (DOE).

The objective of UHIPP is to investigate the use of HIR strategies to reduce cooling energy use in buildings and to reduce the ambient air temperature. Cooling of the ambient air temperature has the additional benefit of reducing urban smog concentration, and hence, improving urban air quality. Baton Rouge, LA, Sacramento, CA and Salt Lake City, UT were selected for UHIPP. Since the inception of the project, Lawrence Berkeley National Laboratory (LBNL) has conducted detailed studies to investigate the impact of HIR strategies on heating and cooling energy use of the three selected pilot cities. In addition, LBNL has collected urban surface characteristic data and conducted preliminary meteorology and urban smog simulations for the three pilot cities.

This report summarizes our efforts to calculate the annual energy savings, peak power avoidance and annual $\mathrm{CO}_{2}$ reduction of HIR strategies in Baton Rouge, Sacramento and Salt Lake City. In this analysis, we focused on three major building types that offer most savings potential: residence, office and retail store. Each building type was characterized in detail by old or new construction and with a gas furnace or an electric heat pump. We defined prototypical building characteristics for each building type and simulated the impact of HIR strategies on building cooling and heating energy use. The simulations included the impact of:

1. strategically-placed shade trees near building [direct effect]

2. use of high-albedo roofing material on building [direct effect]

3. combined strategies 1 and 2 [direct effect]

4. urban reforestation with high-reflective pavements and building surfaces [indirect effect]

5. combined strategies 1,2 and 4 [direct and indirect effects]. 
Table 1.1. Metropolitan-wide estimates of cooling and heating direct energy savings, avoided peak power and carbon reduction from the use of high-albedo roofs for residential and commercial buildings in eleven Metropolitan Statistical Areas [Konopacki et al. 1997].

\begin{tabular}{|l||c||cc||cc||c||c|}
\hline \multicolumn{1}{|c||}{ metropolitan statistical area } & $\begin{array}{c}\text { annual } \\
\text { energy } \\
\text { savings } \\
\text { [M\$] }\end{array}$ & \multicolumn{2}{|c||c||c||c|}{$\begin{array}{c}\text { annual } \\
\text { electricity } \\
\text { savings } \\
\text { [BWh] }\end{array}$} & $\begin{array}{c}\text { annual } \\
\text { natural gas } \\
\text { deficit } \\
\text { [Mth] }\end{array}$ & $\begin{array}{c}\text { peak } \\
\text { power } \\
\text { avoided }\end{array}$ & $\begin{array}{c}\text { annual } \\
\text { carbon } \\
\text { [MW] }\end{array}$ & $\begin{array}{c}\text { [Mduction } \\
\text { [kt] }\end{array}$ \\
\hline \hline Atlanta & 9 & 147 & 11 & 4 & 3 & 97 & 25 \\
Chicago/Gary/Lake County & 10 & 183 & 18 & 15 & 8 & 145 & 31 \\
Dallas/Fort Worth & 20 & 312 & 23 & 6 & 3 & 211 & 52 \\
Houston/Galveston/Brazoria & 27 & 322 & 29 & 3 & 2 & 156 & 54 \\
Los Angeles/Anaheim/Riverside & 35 & 419 & 39 & 6 & 4 & 320 & 70 \\
Miami/Fort Lauderdale & 20 & 256 & 20 & 0 & 0 & 125 & 43 \\
New Orleans & 9 & 117 & 9 & 1 & 1 & 42 & 20 \\
New York/N. New Jersey/Long I. & 16 & 166 & 22 & 9 & 6 & 151 & 28 \\
Philadelphia/Wilmington/Trenton & 3 & 91 & 11. & 12 & 8 & 157 & 15 \\
Phoenix & 37 & 357 & 37 & 1 & 1 & 123 & 60 \\
Washington DC/Baltimore & 8 & 227 & 16 & 10 & 8 & 214 & 38 \\
\hline
\end{tabular}

a Konopacki, S., H. Akbari, M. Pomerantz, S. Gabersek and L. Gartland. 1997. "Cooling Energy Savings Potential of Light-Colored Roofs for Residential and Commercial Buildings in 11 U.S. Metropolitan Areas". Lawrence Berkeley National Laboratory Report LBNL-39433. Berkeley, CA.

b The conversion from BWh to carbon is for the U.S. mix of electricity. In 1995, DOE/EIA-0383(97) [EIA 1997] shows that 3000 BkWh sold emitted $500 \mathrm{MtC}$ (million metric tons of carbon), thus $1 \mathrm{BWh}$ emits $0.167 \mathrm{ktC}$. 


\section{Methodology}

A methodology was developed that incorporates readily obtainable data from building energy simulations, previous heat island studies and the US Census to estimate the potential metropolitan-wide benefits of HIR strategies.

1. Define prototypical building characteristics in detail for old and new construction. Prototypical building data were identified and used to define construction, internal load and cooling and heating equipment characteristics for residential, office, and retail buildings. The placement of shade trees around the building and the use of low and high-albedo roofs were considered. These data then defined the characteristics of the building description language used by the DOE-2.1E energy simulation program.

2. Simulate annual energy use and peak power demand using the DOE-2.1E model. Annual cooling and heating energy use and peak power demand were simulated with DOE-2 using Typical Meteorological Year (TMY2) weather data and modified TMY2 (represents the indirect effect) for all building prototypes, HIR scenarios and pilot cities. Local residential and commercial electricity and natural gas prices for 1997 were applied to the simulation results to obtain total annual energy use in dollars.

3. Determine direct and indirect energy savings from each HIR strategy. Simulated annual cooling and heating energy savings and avoided peak power were calculated by comparing the base case energy use and demand to those of HIR strategies.

4. Identify the total roof area of air-conditioned buildings in each city. Total airconditioned roof area for the entire metropolitan area were estimated for residential, office and retail buildings. Residential roof area were calculated with normalized roof area from Konopacki et al. (1997), data obtained from the 1990 US Census and the American Housing Survey (AHS). Commercial building roof area were derived from the Konopacki et al. (1997) commercial estimates and residential roof area calculated in this report.

5. Calculate the metropolitan-wide impact of HIR strategies. Combine building energy simulations with total air-conditioned roof area for each prototype and strategy.

\section{Building Descriptions}

Three major building prototypes have been selected for investigation in this project: residence, office, and retail store. Konopacki et al. (1997), in a detailed study to quantify the impact of high-albedo roofs in eleven Metropolitan Statistical Areas (MSAs), showed that these three building types accounted for $93 \%$ of the residential and commercial conditioned roof area. The buildings were characterized for old (those built prior to 1980) or new (built 1980 or later) construction and with a gas furnace or an electric heat pump. Detailed construction, equipment, and interior load data were available from studies of Northern California commercial buildings (Akbari et al. 1993) and Sacramento residential and commercial buildings (CEC 1994), and were used to define the prototypes in all three cities (quality data were unavailable for old construction buildings in Baton Rouge and Salt Lake city). Characteristics for new construction residences were identified from DOE national appliance energy standards (NAECA 1987), California's Title-24, and the Model Energy Code. All three buildings were single-story prototypes with either an attic or plenum space which contains $a / c$ ducts. Old construction buildings were modeled with $\mathrm{R}-11$ attic/plenum insulation and the new with R-30. 


\section{Residence}

The residence was modeled as a single-family, ranch-style building with a detached garage, with characteristics identified in Table 2.1, and in four orientations. The exterior dimensions were 55 by $28 \mathrm{ft}$ with a total conditioned floor area of $1540 \mathrm{ft}^{2}$. The exposed wall area was $1328 \mathrm{ft}^{2}$. Distinct windows were placed on each wall with a window-to-wall ratio of 0.17 . Operable shades were employed on the windows. The residence operated from $7 \mathrm{am}$ to $10 \mathrm{pm}$ seven days a week.

The roof was constructed with asphalt shingles on a $20^{\circ}$ sloped plywood deck, over a naturally ventilated and unconditioned attic, above a studded ceiling frame with fiberglass insulation, and with a sheet of drywall beneath. The attic ventilation to floor area ratio was set at 1:400 and variable air infiltration was modeled by the Sherman-Grimsrud algorithm (Sherman 1986).

The residence was cooled and heated by a central air-conditioning system with ducts located in the attic, a constant volume fan and without an economizer. Modified part-load-ratio curves for a typical air conditioner, heat pump, and gas furnace were used in place of the standard DOE-2 curves, since they have been shown to model low-load energy use more accurately (Henderson 1998). The systems were sized based on peak cooling and heating loads as determined by DOE-2, which allowed for peak loads to be met and for maximum savings to be calculated. Duct loads were simulated with a validated residential attic-duct function ${ }^{4}$ (Parker et al. 1998) implemented into DOE-2 to better estimate the thermal interactions between the ducts and the attic space. Cooling through natural ventilation was available through window operation.

\section{Office}

The office was modeled as a rectangular building with four perimeter zones and a core zone, with characteristics identified in Table 2.2, and two orientations (north/south and east/west symmetric). The exterior dimensions were 80 by $50 \mathrm{ft}$ with a total conditioned floor area of $4000 \mathrm{ft}^{2}$. The perimeter zone depth was $15 \mathrm{ft}$. The exposed wall area was $2340 \mathrm{ft}^{2}$ and the windows wrapped continuously around the building with a window-to-wall ratio of 0.5 . Operable shades were employed on the windows. The building operated from $6 a \mathrm{~m}$ to $7 \mathrm{pm}$ on weekdays.

The roof was constructed with built-up materials on a flat plywood deck, over an unventilated and unconditioned plenum, above a studded ceiling frame with fiberglass insulation, and with a sheet of drywall beneath.

The building was cooled and heated by five rooftop, direct expansion, constant volume, packaged-single-zone systems, each one servicing a single zone. The systems were sized based on peak cooling and heating loads as determined by DOE-2, which allowed for peak loads to be met and for maximum savings to be calculated. Duct loads were simulated by specifying air leakage and temperature drop. An economizer was also implemented.

\section{Retail Store}

The retail store was modeled as a rectangular building with a single zone, as part of a strip mall with other buildings on two sides, with characteristics identified in Table 2.3, and in three orientations. The exterior dimensions were 100 by $80 \mathrm{ft}$ with $8000 \mathrm{ft}^{2}$ of total conditioned floor area.

\footnotetext{
4 The function calculates attic temperature, supply and return duct losses, and temperature-dependent heat conduction through the insulation. It was documented to provide reasonable agreement with measured attic temperature and air-conditioning electricity use data taken from Florida test homes.
} 
Table 2.1. Residence prototypical construction, equipment, and interior load characteristics.

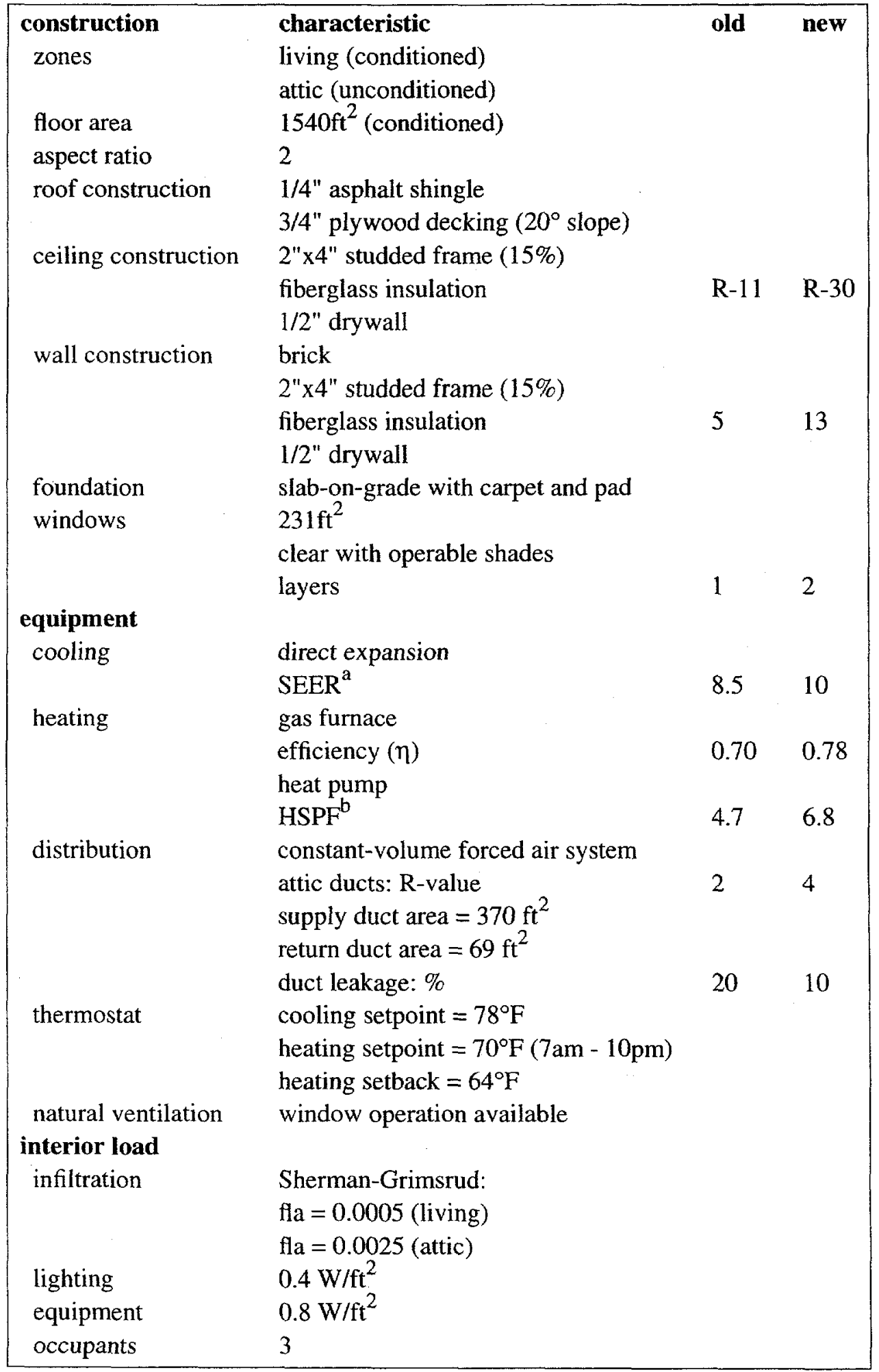


Table 2.2. Office prototypical construction, equipment, and interior load characteristics.

\begin{tabular}{|c|c|c|c|}
\hline construction & characteristic & old & new \\
\hline zones & 5 (conditioned) & & \\
\hline floor area & $4000 \mathrm{ft}^{2}$ (conditioned) & & \\
\hline aspect ratio & 1.6 & & \\
\hline \multirow[t]{2}{*}{ roof construction } & built-up roofing & & \\
\hline & $\begin{array}{l}3 / 4 " \text { plywood decking }\left(0^{\circ} \text { slope) }\right. \\
\text { plenum (unconditioned) }\end{array}$ & & \\
\hline \multirow[t]{2}{*}{ ceiling construction } & $2 " x 4 "$ studded frame (15\%) & & \\
\hline & fiberglass insulation & $\mathrm{R}-11$ & $\mathrm{R}-30$ \\
\hline \multirow[t]{3}{*}{ wall construction } & brick & & \\
\hline & $2 " x 4 "$ studded frame $(15 \%)$ & & \\
\hline & $\begin{array}{l}\text { fiberglass insulation } \\
1 / 2^{\prime \prime} \text { drywall }\end{array}$ & 6 & 13 \\
\hline $\begin{array}{l}\text { foundation } \\
\text { windows }\end{array}$ & $\begin{array}{l}\text { slab-on-grade with carpet and pad } \\
1170 \mathrm{ft}^{2} \\
\text { clear with operable shades }^{2}\end{array}$ & & \\
\hline & layers & 1 & 2 \\
\hline \multicolumn{4}{|l|}{ equipment } \\
\hline \multirow[t]{2}{*}{ cooling } & direct expansion & & \\
\hline & COP & 2.25 & 2.9 \\
\hline \multirow[t]{2}{*}{ heating } & gas furnace & & \\
\hline & $\begin{array}{l}\text { efficiency }(\eta) \\
\text { heat pump }\end{array}$ & 0.70 & 0.74 \\
\hline \multirow{3}{*}{ distribution } & $\begin{array}{l}\text { COP } \\
\text { constant-volume forced air system }\end{array}$ & 2.25 & 2.9 \\
\hline & economizer & fixed & temperature \\
\hline & duct leakage: $\%$ & 20 & 10 \\
\hline thermostat & $\begin{array}{l}\text { duct temperature drop: }{ }^{\circ} \mathrm{F} \\
\text { weekday operation }(6 \mathrm{am}-7 \mathrm{pm}) \\
\text { cooling setpoint }=78^{\circ} \mathrm{F} \\
\text { heating setpoint }=70^{\circ} \mathrm{F}\end{array}$ & 2 & 1 \\
\hline \multicolumn{4}{|l|}{ interior load } \\
\hline infiltration & air-change/hour $=0.5$ & & \\
\hline lighting & $\mathrm{W} / \mathrm{ft}^{2}$ & 1.9 & 1.4 \\
\hline equipment & $\mathrm{W} / \mathrm{ft}^{2}$ & 1.7 & 1.5 \\
\hline occupants & 25 & & \\
\hline
\end{tabular}


Table 2.3. Retail Store prototypical construction, equipment, and interior load characteristics.

\begin{tabular}{|c|c|c|c|}
\hline construction & characteristic & old & new \\
\hline zones & 1 (conditioned) & & \\
\hline floor area & $8000 \mathrm{ft}^{2}$ (conditioned) & & \\
\hline aspect ratio & 1.25 & & \\
\hline \multirow[t]{3}{*}{ roof construction } & built-up roofing & & \\
\hline & $3 / 4^{\prime \prime}$ plywood decking ( $0^{\circ}$ slope) & & \\
\hline & plenum (unconditioned) & & \\
\hline \multirow[t]{3}{*}{ ceiling construction } & $2 " x 4 "$ studded frame $(15 \%)$ & & \\
\hline & fiberglass insulation & $\mathrm{R}-11$ & $\mathrm{R}-30$ \\
\hline & $1 / 2^{\prime \prime}$ drywall & & \\
\hline \multirow[t]{3}{*}{ wall construction } & brick & & \\
\hline & $2 " x 4 "$ studded frame $(15 \%)$ & & \\
\hline & $\begin{array}{l}\text { fiberglass insulation } \\
1 / 2 " \text { drywall }\end{array}$ & 4 & 13 \\
\hline foundation & slab-on-grade with carpet and pad & & \\
\hline \multirow[t]{3}{*}{ windows } & $540 \mathrm{ft}^{2}$ (south) & & \\
\hline & clear without operable shades & & \\
\hline & layers & 1 & 2 \\
\hline \multicolumn{4}{|l|}{ equipment } \\
\hline \multirow[t]{2}{*}{ cooling } & direct expansion & & \\
\hline & $\mathrm{COP}$ & 2.25 & 2.9 \\
\hline \multirow[t]{3}{*}{ heating } & gas furnace & & \\
\hline & $\begin{array}{l}\text { efficiency }(\eta) \\
\text { heat pump }\end{array}$ & 0.70 & 0.74 \\
\hline & $\mathrm{COP}$ & 2.25 & 2.9 \\
\hline \multirow[t]{4}{*}{ distribution } & constant-volume forced air system & & \\
\hline & economizer & fixed & temperature \\
\hline & duct leakage: $\%$ & 20 & 10 \\
\hline & duct temperature drop: ${ }^{\circ} \mathrm{F}$ & 3 & 1 \\
\hline thermostat & $\begin{array}{l}\text { weekday operation }(8 \mathrm{am}-9 \mathrm{pm}) \\
\text { weekend operation }(10 \mathrm{am}-5 \mathrm{pm}) \\
\text { cooling setpoint }=78^{\circ} \mathrm{F} \\
\text { heating setpoint }=70^{\circ} \mathrm{F}\end{array}$ & & \\
\hline \multicolumn{4}{|l|}{ interior load } \\
\hline infiltration & air-change/hour $=0.5$ & & \\
\hline lighting & $\mathrm{W} / \mathrm{ft}^{2}$ & 2.4 & 1.7 \\
\hline equipment & $\mathrm{W} / \mathrm{ft}^{2}$ & 0.7 & 0.6 \\
\hline occupants & 16 & & \\
\hline
\end{tabular}


The exterior dimensions were 100 by $80 \mathrm{ft}$ with a total conditioned floor area of $8000 \mathrm{ft}^{2}$. The exposed wall area was $1800 \mathrm{ft}^{2}$ (unexposed $1440 \mathrm{ft}^{2}$ ) and a continuous window was situated on the south wall only (north facing orientation) with a window-to-wall ratio of 0.6 . Operable shades were not employed on the windows. The building operated from 8 am to $9 \mathrm{pm}$ on weekdays and from $10 \mathrm{am}$ to $5 \mathrm{pm}$ on weekends or holidays.

The roof was constructed with built-up materials on a flat plywood deck, over an unventilated and unconditioned plenum, above a studded ceiling frame with fiberglass insulation, and with a sheet of drywall beneath.

The building was cooled and heated by a single rooftop, direct expansion, constant volume, packaged-single-zone system. The systems were sized based on peak cooling and heating loads as determined by DOE-2, which allowed for peak loads to be met and for maximum savings to be calculated. Duct loads were simulated by specifying air leakage and temperature drop. An economizer was also implemented.

\section{Direct vs. Indirect Effect}

Strategies to cool cities and mitigate urban heat islands include planting shade trees around buildings, planting other urban vegetation in parks and along roadways, and using high-albedo roofs and pavements. Trees shade buildings and high-albedo roofs reflect solar energy from buildings, directly reducing demand for air-conditioning $(\mathrm{a} / \mathrm{c})$. Urban vegetation and reflective surfaces (high-albedo roofs and pavements) alter the surface energy balance of an area through evapotranspiration of vegetation and by reflecting incident solar energy, lowering the ambient temperature and hence indirectly reducing $a / c$ use.

The direct energy impacts are simulated with the building energy software DOE- 2 . The indirect energy impacts are estimated in a two-step process. First, a modified TMY2 weather tape was created to represent the impact of HIR strategies. Second, the prototypes were simulated with the modified weather tape to calculate the impact of ambient cooling on heating and cooling energy use.

To quantify the ambient cooling from the indirect effect, first, a modified urban fabric is created from the present fabric with increased urban vegetation, the planting of shade trees, and the use of high-albedo roofs and pavements. Second, the impact of the modified urban fabric on climate is simulated using the Colorado State Urban Meteorological Model (CSUMM), from which a modified average drybulb air temperature is obtained from several locations within the boundaries of the model over the 48 hour episode beginning 27 July; discussed in detail by Taha and Chang (1999a). Then, the modified temperature is calculated for each hour of the year using an algorithm developed by Taha (1999b) based on a statistical analysis of temperature change as a function of solar intensity; because $\Delta \mathrm{T}$ is solely a function of solar, $\Delta \mathrm{T}$ is zero during hours without sunlight. Finally, $\Delta \mathrm{T}$ is used to modify the standard TMY2 weather data to create modified temperature data for the building energy simulations.

A decreased air temperature due to the modification of the urban fabric may also occur during non-solar hours and could mostly affect residential cooling and heating energy use, as the office and retail buildings typically do not operate late evening and early morning. The lowered air temperature in the evening/morning would add to residential cooling energy savings and heating energy penalties, unless natural ventilation or evening venting were cooling the building during these hours. The extrapolation of episodic $\Delta \mathrm{T}$ to an annual scale is being studied further. 


\section{Shade Trees}

Mature deciduous shade trees were modeled as a box-shaped building shade with seasonal transmittance ${ }^{5}$ (summertime transmittance is 0.1 for April 1 through October 31 and wintertime is 0.9 for the remainder of the year), a cross-section of 15 by $15 \mathrm{ft}$ ( $21 \mathrm{ft}$ radius), a depth of $10 \mathrm{ft}$, and a canopy height of $15 \mathrm{ft}$. They were placed near windows (with $2 \mathrm{ft}$ of clearance from the building) in order to maximize the impact on the building cooling load. The fully grown trees shade a portion of the roof during low sun hours, but do not cover any of the roof.

A total of eight residential shade trees were situated near the east, south, and west walls directly in front of the windows, where the placement differed for north/south and east/west orientations. A total of eight office shade trees were situated near the east, south, and west walls (continuous windows), where the placement differed for north/south and east/west orientations. A total of four retail store shade trees were situated near the south wall (only wall with windows), where the placement was the same for all three orientations.

\section{Roof Albedo}

Typical values of albedo for low- and high-albedo roofs were selected that cover the wide range of commercially available roofing materials (shingles, tiles, membranes and coatings) and the effects of weathering and aging. These were obtained primarily from the Cool Roofing Materials Database (CRMD) developed at LBNL, which contains measured values of roof absorptance across the solar spectrum. ${ }^{6}$ The roof albedo were 0.2 and 0.5 for residential roofs and 0.2 and 0.6 for commercial roofs, which represent low and high albedo materials as shown in Table 5.1. The long-wave thermal emittance of these materials was a uniform 0.9 .

Bretz and Akbari (1997) have reported that the albedo of white-coated roof surfaces can degrade up to $20 \%$ over a period of several years as a result of weathering and accumulation of dirt and debris (microbial growth can contribute to degradation in humid climates such as Baton Rouge), and by washing the roof, the albedo can be restored to $90-100 \%$ of the initial value. Note, rainfall can cleanse a roof effectively and have the same effect as a thorough washing.

A few examples of real materials are shown in the table. A "generic white" asphalt shingle has a laboratory tested initial albedo of 0.25 (CRMD 1998). A "generic grey" asphalt shingle has a laboratory tested initial albedo of 0.22 , and the albedo of a green or brown shingle is about 0.12-0.15 (CRMD 1998). The roofs - built-up asphalt capsheet with light-grey granules - of three commercial buildings in California were coated with a white-elastomeric material, where the measured pre-coated albedo ranged from 0.16 to 0.24 , the initial post-coated albedo was 0.6 , the unwashed albedo ranged from 0.47 to 0.56 , and the washed albedo was 0.59 (Konopacki and Akbari 1998b).

\footnotetext{
5 The fraction of light that passes through the tree is the transmittance.

6 The on-line database can be found at http://eetd.lbl.gov/coolroof (CRMD 1998).
} 
Table 5.1. Roof materials and weathered albedo for residential and commercial buildings.

\begin{tabular}{|l||l||c|}
\hline \multicolumn{1}{|c||}{ building } & \multicolumn{1}{|c|}{ roof material } & roof albedo \\
\hline residential & & \\
low & typical light- or dark-colored asphalt shingle & 0.2 \\
medium & premium white-algaecide or typical 1960's white shingle & 0.3 \\
high & prototype six-coat TiO white shingle & 0.5 \\
commercial & & \\
low & high-albedo granules on asphalt capsheet & 0.2 \\
medium & dirty white-elastomeric coating on asphalt capsheet & 0.4 \\
high & white-elastomeric coating on asphalt capsheet & 0.6 \\
\hline
\end{tabular}

\section{Weather Data}

Local full-year hourly weather data are required as input to the DOE-2 simulation program. Those data used were derived from the 1961-1990 National Solar Radiation Data Base (NREL 1995) and are in the Typical Meteorological Years 2 (TMY2) format. It is important to remark that this format represents typical rather than extreme conditions.

Two sets of weather data were utilized in this exercise: [1] standard [2] modified. As discussed in Chapter 3, the modified data represent a decrease in hourly drybulb temperature as a result of HIR strategies. This change in temperature is termed the indirect effect. The maximum air temperature and degree-hours of the standard TMY2 weather data are compared to that of the modified data and are presented in Table 6.1.

The standard TMY2 for Baton Rouge had twice as many annual cooling degree-hours/24 (2542 at $65^{\circ} \mathrm{F}$ ), than Sacramento (1296) and Salt Lake City (1266). Also, Salt Lake City is heating dominated with 5919 heating degree-hours $/ 24$ at $65^{\circ} \mathrm{F}$, followed by Sacramento (3386) and Baton Rouge (1869). Annual average daily combined sensible and latent enthalpy was highest in Baton Rouge with 27 Btu per pound of dry air, Sacramento with just over 21 and Salt Lake City with 16.

The modified TMY2 had the greatest indirect effect in Sacramento, where the maximum drybulb temperature decreased by $3^{\circ} \mathrm{F}$ and annual cooling degree-hours $/ 24$ by 130 , this was accompanied by an increase in annual heating degree-hours $/ 24$ of 63 . Salt Lake City followed with a $3^{\circ} \mathrm{F}$ decrease in maximum drybulb temperature and 115 fewer annual cooling degreehours $/ 24$, also annual heating degree-hours $/ 24$ increased by 95 . Baton Rouge saw the least impact, with a $2^{\circ} \mathrm{F}$ decrease in maximum drybulb temperature, and 95 fewer annual cooling degree-hours $/ 24$, also annual heating degree-hours/24 increased by 25 . 
Table 6.1. Maximum air temperature and degree-hour data for standard TMY 2 weather and modified ( $\Delta=$ modified - standard).

\begin{tabular}{|c|c|c|c|c|c|c|}
\hline \multirow{2}{*}{ temperature \& degree-hour data } & \multicolumn{2}{|c|}{ Baton Rouge, LA } & \multicolumn{2}{|c|}{ Sacramento, CA } & \multicolumn{2}{|c|}{ Salt Lake City, UT } \\
\hline & standard & $\Delta$ & standard & $\Delta$ & standard & $\Delta$ \\
\hline maximum temperature $\left[{ }^{\circ} \mathrm{F}\right]{ }^{\mathrm{a}}$ & 97 & -2 & 104 & -3 & 101 & -3 \\
\hline cooling degree-hours $/ 24\left[65^{\circ} \mathrm{F}\right]$ & & & & & & \\
\hline June & 423 & -14 & 212 & -24 & 198 & -23 \\
\hline July & 458 & -14 & 311 & -26 & 450 & -29 \\
\hline August & 473 & -14 & 302 & -22 & 375 & -26 \\
\hline annual & 2542 & -95 & 1296 & -130 & 1266 & -115 \\
\hline heating degree-hours $/ 24\left[65^{\circ} \mathrm{F}\right]$ & & & & & & \\
\hline January & 414 & 4 & 608 & 6 & 1139 & 7 \\
\hline February & 356 & 5 & 426 & 9 & 848 & 10 \\
\hline December & 432 & 5 & 618 & 5 & 1085 & 6 \\
\hline annual & 1869 & 25 & 3386 & 63 & 5919 & 95 \\
\hline
\end{tabular}

a The maximum standard ambient air temperature and the maximum modified temperature decrease are non-concurrent.

\section{Energy Prices}

The local 1997 average prices of electricity and natural gas were obtained from the Energy Information Administration web page (EIA 1998) for residential and commercial sectors as displayed in Table 7.1. These were utilized to calculate the annual combined cost of cooling and heating energy use. Average revenue per kilowatthour were listed for the utility serving the locality and the average price of gas was given by state.

Table 7.1. Average 1997 prices of electricity and gas for residential and commercial sectors.

\begin{tabular}{|c|c|c|c|c|}
\hline \multirow{2}{*}{ location } & \multicolumn{2}{|c|}{ residential } & \multicolumn{2}{|c|}{ commercial } \\
\hline & electricity $[\$ / \mathrm{kWh}]$ & gas [\$/therm] ${ }^{6}$ & electricity $[\$ / \mathrm{kWh}]^{\mathrm{c}}$ & gas [\$/therm] \\
\hline Baton Rouge, LA & 0.0739 & 0.716 & 0.0699 & 0.622 \\
\hline Sacramento, CA & 0.0835 & 0.681 & 0.0824 & 0.643 \\
\hline Salt Lake City, UT & 0.0693 & 0.513 & 0.0560 & 0.391 \\
\hline
\end{tabular}

Energy Information Administration (EIA 1998). Table 14. Class of ownership, number of ultimate consumers, revenue, sales, and average revenue per kilowatt-hour for the residential sector by state and utility, 1997. http://www.eia.doe.gov/cneaf/electricity/esr/esr_tabs.html.

b Energy Information Administration (EIA 1998). Table 24. Average price of natural gas delivered to residential consumers by state, 1993 to 1997. http://www.eia.doe.gov/oil_gas/natural_gas/nat_frame.html.

c Energy Information Administration (EIA 1998). Table 15. Class of ownership, number of ultimate consumers, revenue, sales, and average revenue per kilowatt-hour for the commercial sector by state and utility, 1997. http://www.eia.doe.gov/cneaf/electricity/esr/esr_tabs.html.

d Energy Information Administration (EIA 1998). Table 25. Average prices of natural gas to consumers by state, 1997. http://www.eia.doe.gov/oil_gas/natural_gas/nat_frame.html. 


\section{Simulated Energy Use \& Savings and Peak Power Demand \& Savings}

Annual cooling and heating energy use and cooling peak power demand were simulated with the DOE-2.1E building energy simulation program (BESG 1990) using local TMY2 weather data for residential, office and retail store prototypical buildings. The residential building description language was adapted with a validated attic-duct function developed by Parker et al. (1998) to better estimate the thermal interactions between the ducts and attic space. Each prototype was characterized by old (built prior to 1980) or new (built 1980 or later) construction and with a gas furnace or an electric heat pump. The simulations were performed for a base case, defined as a building without shade trees and a low-albedo roof of 0.2 , and five modified cases:

1. strategically-placed shade trees near building [direct effect]

2. use of high-albedo roofing material on building [direct effect]

3. combined strategies 1 and 2 [direct effect]

4. urban reforestation with high-reflective pavements and building surfaces [indirect effect]

5. combined strategies 1,2 and 4 [direct and indirect effects].

The modified cases had a roof albedo of 0.5 for residence and 0.6 for commercial buildings. The number of shade trees considered for the residence and office was eight and for retail was four.

The simulations provided estimates of annual cooling and heating electricity use $\left[\mathrm{kWh} / 1000 \mathrm{ft}^{2}\right]$, annual heating natural gas use [therms $\left./ 1000 \mathrm{ft}^{2}\right]$ and cooling peak power demand $\left[\mathrm{kW} / 1000 \mathrm{ft}^{2}\right]$. From the simulations, the annual total expenditures for cooling and heating energy [ $\$ / 1000 \mathrm{ft}^{2}$ ] could then be calculated using local energy prices. Using the base case as a reference, annual energy and peak power savings were determined for each HIR strategy. The base expenditure \& demand and savings for the average building orientation are presented in Tables 8.1(a,b), 8.2(a,b) and 8.3(a,b). Tables (a) show the savings in absolute terms $\left[\$ / 1000 \mathrm{ft}^{2}\right.$ or $\left.\mathrm{kW} / 1000 \mathrm{ft}^{2}\right]$ and (b) as a percentage [\%]. Results for all simulations are presented in the tables of Appendix A. Consider points a-f upon examination of the tables.

a. Results are calculated per $1000 \mathrm{ft}^{2}$ of roof area and can be applied to multi-story buildings.

b. Linear interpolation can be used to estimate savings or penalties for other net changes in albedo $\left(\Delta \mathrm{a}_{2}\right)$ than presented here $\left(\Delta \mathrm{a}_{1}\right)$ (Konopacki et al. 1997). Therefore, the results presented in the tables can be simply adjusted by the ratio $\Delta \mathrm{a}_{2} / \Delta \mathrm{a}_{1}$ to obtain estimates for other combinations of albedo. Linear interpolation is also valid for shade trees.

c. It is important to note that the combined HIR effects are not precisely the sum of individual effects, for example, direct shade tree and direct high albedo savings may not sum precisely to direct combined savings.

d. Savings will increase for buildings with less roof insulation than that specified in these prototypes (R-11 for old construction \& R-30 for new). Conversely, savings will decrease for those with more roof insulation.

e. These buildings have $\mathrm{a} / \mathrm{c}$ ducts in either the attic or plenum space. Savings will decrease for buildings with $\mathrm{a} / \mathrm{c}$ ducts in the conditioned space and for those without ducts.

f. Savings in peak power make it clear that an air conditioner can be down-sized when HIR strategies are considered. 
In Baton Rouge, the simulations predicted combined direct and indirect savings in annual total energy of $58 \& 34 \$ / 1000 \mathrm{ft}^{2}(13 \& 15 \%)$ and in peak power of $0.57 \& 0.35 \mathrm{~kW} / 1000 \mathrm{ft}^{2} \cdot(17$ $\& 18 \%)$ for old and new gas heated residences, $95 \& 54 \$ / 1000 \mathrm{ft}^{2}(10 \& 11 \%)$ and $0.59 \& 0.30$ $\mathrm{kW} / 1000 \mathrm{ft}^{2}(8 \& 7 \%)$ for old and new gas heated for offices, and $139 \& 52 \$ / 1000 \mathrm{ft}^{2}(14 \& 12 \%)$ and 0.54 to $0.32 \mathrm{~kW} / 1000 \mathrm{ft}^{2}(11 \& 12 \%)$ for old and new gas heated retail stores. The indirect effect accounted for 1-3\% of these savings. The annual natural gas deficit for the combined direct and indirect effects of the old residence was $24 \%$ of the $76 \$ / 1000 \mathrm{ft}^{2}$ in electricity savings, $13 \%$ of $39 \$ / 1000 \mathrm{ft}^{2}$ for the new residence and $4 \%$ of $99 \$ / 1000 \mathrm{ft}^{2}$ for the old office (new office and retail had negligible or zero gas penalty).

In Sacramento, the simulations predicted combined direct and indirect savings in annual total energy of $24 \& 16 \$ / 1000 \mathrm{ft}^{2}(6 \& 10 \%)$ and in peak power of $0.74 \& 0.43 \mathrm{~kW} / 1000 \mathrm{ft}^{2}(21 \&$ $22 \%$ ) for old and new gas heated residences, $160 \& 66 \$ / 1000 \mathrm{ft}^{2}(16 \& 15 \%)$ and $1.16 \& 0.48$ $\mathrm{kW} / 1000 \mathrm{ft}^{2}(15 \& 11 \%)$ for old and new gas heated for offices, and $188 \& 76 \$ / 1000 \mathrm{ft}^{2}(18 \&$ $19 \%)$ and 0.96 to $0.57 \mathrm{~kW} / 1000 \mathrm{ft}^{2}(16 \& 19 \%)$ for old and new gas heated retail stores. The indirect effect accounted for $2-4 \%$ of these savings. The annual natural gas deficit for the combined direct and indirect effects of the old residence was $65 \%$ of the $68 \$ / 1000 \mathrm{ft}^{2}$ in electricity savings, $52 \%$ of $33 \$ / 1000 \mathrm{ft}^{2}$ for the new residence and $4 \%$ of $166 \$ / 1000 \mathrm{ft}^{2}$ for the old office (new office and retail had negligible or zero gas penalty).

In Salt Lake City, the simulations predicted combined direct and indirect savings in annual total energy of $3 \& 4 \$ / 1000 \mathrm{ft}^{2}(0 \& 1 \%)$ and in peak power of $0.66 \& 0.34 \mathrm{~kW} / 1000 \mathrm{ft}^{2}(19 \&$ $18 \%$ ) for old and new gas heated residences, $94 \& 41 \$ / 1000 \mathrm{ft}^{2}(15 \& 13 \%)$ and $1.19 \& 0.67$ $\mathrm{kW} / 1000 \mathrm{ft}^{2}(16 \& 17 \%)$ for old and new gas heated for offices, and $107 \& 43 \$ / 1000 \mathrm{ft}^{2}(18 \%)$ and 0.77 to $0.38 \mathrm{~kW} / 1000 \mathrm{ft}^{2}(15 \%)$ for old and new gas heated retail stores. The indirect effect accounted for $0-5 \%$ of these savings. The annual natural gas deficit for the combined direct and indirect effects of the old residence was $94 \%$ of the $49 \$ / 1000 \mathrm{ft}^{2}$ in electricity savings, $83 \%$ of 24 $\$ / 1000 \mathrm{ft}^{2}$ for the new residence, $7 \%$ of $101 \$ / 1000 \mathrm{ft}^{2}$ for the old office, $11 \%$ of $46 \$ / 1000 \mathrm{ft}^{2}$ for the new office and $3 \%$ of $110 \$ / 1000 \mathrm{ft}^{2}$ for the old retail (new retail had negligible gas penalty). Upon examination of table $8.3(\mathrm{a})$ it is evident that there were three cases in which a negative annual total energy savings occurred. The energy penalties (negative savings) are all $-1 \%$ or zero and occurred in residences: (1) old, gas furnace and shade trees, (2) old, electric heat pump and high-albedo roof, and (3) new, electric heat pump and high-albedo roof. If snow covers all or some portion of the roof, the heating penalty will be lower than cited in the tables. 
Table 8.1(a). Baton Rouge simulated cooling and heating annual base energy expenditures and savings [ $\$ / 1000 \mathrm{ft}^{2}$ ], and peak power demand and savings [ $\left.\mathrm{kW} / 1000 \mathrm{ft}^{2}\right]$ from Heat Island Reduction (HIR) strategies for residential and commercial buildings. Direct savings are from the strategic placement of shade trees and the use of high-albedo roofs on individual buildings, and indirect savings include the impact of reduced air temperature from urban reforestation and high-albedo surfaces.

\begin{tabular}{|c|c|c|c|c|c|c|c|c|c|c|}
\hline \multirow{2}{*}{$\begin{array}{c}\text { building type } \\
\qquad \& \\
\text { HIR strategy } \\
\end{array}$} & \multicolumn{4}{|c|}{ annual total energy } & \multicolumn{2}{|c|}{$\begin{array}{c}\text { annual electricity } \\
\text { gas heat }\end{array}$} & \multicolumn{2}{|c|}{$\begin{array}{l}\text { annual gas } \\
\text { gas heat }\end{array}$} & \multicolumn{2}{|c|}{$\begin{array}{c}\text { peak power } \\
\text { gas \& electric heat }\end{array}$} \\
\hline & -1979 & $1980+$ & -1979 & $1980+$ & -1979 & $1980+$ & -1979 & $1980+$ & -1979 & $1980+$ \\
\hline residence & & & & & & & & & & \\
\hline base expenditure \& demand & 448 & 231 & 531 & 248 & 324 & 189 & 124 & 42 & 3.42 & 1.95 \\
\hline direct shade tree savings & 19 & 15 & 26 & 16 & 29 & 18 & -10 & -3 & 0.26 & 0.22 \\
\hline direct high albedo savings & 34 & 15 & 30 & 14 & 38 & 16 & -4 & -1 & 0.27 & 0.12 \\
\hline direct combined savings & 51 & 30 & 53 & 30 & 65 & 34 & -14 & -4 & 0.52 & 0.33 \\
\hline indirect savings & 9 & 6 & 8 & 6 & 12 & 7 & -3 & -1 & 0.05 & 0.02 \\
\hline $\begin{array}{l}\text { direct \& indirect savings } \\
\text { office }\end{array}$ & 58 & 34 & 60 & 34 & 76 & 39 & -18 & -5 & 0.57 & 0.35 \\
\hline base expenditure $\&$ demand & 995 & 516 & 1006 & 518 & 945 & 505 & 50 & 11 & 7.81 & 4.47 \\
\hline direct shade tree savings & 29 & 14 & 28 & 14 & 30 & 15 & -1 & -1 & 0.08 & 0.04 \\
\hline direct high albedo savings & 50 & 17 & 50 & 17 & 54 & 18 & -4 & -1 & 0.23 & 0.12 \\
\hline direct combined savings & 77 & 31 & 76 & 31 & 80 & 32 & -3 & -1 & 0.33 & 0.18 \\
\hline indirect savings & 18 & 10 & 18 & 10 & 19 & 11 & -1 & -1 & 0.23 & 0.12 \\
\hline $\begin{array}{l}\text { direct \& indirect savings } \\
\text { retail }\end{array}$ & 95 & 54 & 94 & 55 & 99 & 56 & -4 & -2 & 0.59 & 0.30 \\
\hline base expenditure \& demand & 973 & 444 & 976 & 444 & 963 & 444 & 10 & 0 & 5.09 & 2.60 \\
\hline direct shade tree savings & 37 & 22 & 37 & 22 & 37 & 22 & 0 & 0 & 0.09 & 0.05 \\
\hline direct high albedo savings & 73 & 27 & 73 & 27 & 74 & 27 & -1 & 0 & 0.34 & 0.18 \\
\hline direct combined savings & 112 & 45 & 112 & 45 & 114 & 45 & -2 & 0 & 0.46 & 0.28 \\
\hline indirect savings & 13 & 8 & 13 & 8 & 13 & 8 & 0 & 0 & 0.08 & 0.04 \\
\hline direct $\&$ indirect savings & 139 & 52 & 139 & 52 & 141 & 52 & -2 & 0 & 0.54 & 0.32 \\
\hline
\end{tabular}

a Base energy expenditures and peak power demand are calculated for buildings without shade trees and with a dark roof (albedo 0.2). Direct savings are determined for buildings with 8 shade trees (retail 4) and a high-albedo roof (residential 0.5 and commercial 0.6). To estimate direct savings for other changes in albedo $(\Delta \mathrm{a})$ multiply the savings by the ratio $\Delta \mathrm{a} / 0.3$ for residences and $\Delta \mathrm{a} / 0.4$ for commercial buildings.

b Combined HIR effects are not precisely the sum of individual effects. 
Table 8.1(b). Baton Rouge simulated cooling and heating annual base energy expenditures $\left[\$ / 1000 \mathrm{ft}^{2}\right]$ and savings [\%], and peak power demand $\left[\mathrm{kW} / 1000 \mathrm{ft}^{2}\right]$ and savings [\%] from Heat Island Reduction (HIR) strategies for residential and commercial buildings. Direct savings are from the strategic placement of shade trees and the use of high-albedo roofs on individual buildings, and indirect savings include the impact of reduced air temperature from urban reforestation and high-albedo surfaces.

\begin{tabular}{|c|c|c|c|c|c|c|c|c|c|c|}
\hline \multirow{3}{*}{$\begin{array}{c}\text { building type } \\
\& \\
\text { HIR strategy }\end{array}$} & \multicolumn{4}{|c|}{ annual total energy } & \multirow{2}{*}{\multicolumn{2}{|c|}{$\begin{array}{c}\text { annual electricity } \\
\text { gas heat }\end{array}$}} & \multirow{2}{*}{\multicolumn{2}{|c|}{$\begin{array}{c}\text { annual gas } \\
\text { gas heat }\end{array}$}} & \multirow{2}{*}{\multicolumn{2}{|c|}{$\begin{array}{c}\text { peak power } \\
\text { gas \& electric heat }\end{array}$}} \\
\hline & \multicolumn{2}{|c|}{ gas heat } & \multicolumn{2}{|c|}{ electric heat } & & & & & & \\
\hline & -1979 & $1980+$ & -1979 & $1980+$ & -1979 & $1980+$ & -1979 & $1980+$ & -1979 & $1980+$ \\
\hline \multicolumn{11}{|l|}{ residence } \\
\hline base expenditure \& demand & 448 & 231 & 531 & 248 & 324 & 189 & 124 & 42 & 3.42 & 1.95 \\
\hline direct shade tree savings [\%] & 4 & 6 & 5 & 7 & 9 & 10 & -8 & -8 & 8 & 11 \\
\hline direct high albedo savings [\%] & 7 & 6 & 6 & 6 & 12 & 8 & -3 & -3 & 8 & 6 \\
\hline direct combined savings [\%] & 11 & 13 & 10 & 12 & 20 & 18 & -11 & -11 & 15 & 17 \\
\hline indirect savings [\%] & 2 & 3 & 2 & 2 & 4 & 4 & -2 & -2 & 1 & 1 \\
\hline direct \& indirect savings [\%] & 13 & 15 & 11 & 14 & 24 & 21 & -15 & -12 & 17 & 18 \\
\hline \multicolumn{11}{|l|}{ office } \\
\hline base expenditure \& demand & 995 & 516 & 1006 & 518 & 945 & 505 & 50 & 11 & 7.81 & 4.47 \\
\hline direct shade tree savings [\%] & 3 & 3 & 3 & 3 & 3 & 3 & -2 & -5 & 1 & 1 \\
\hline direct high albedo savings [\%] & 5 & 3 & 5 & 3 & 6 & 4 & -8 & -9 & 3 & 3 \\
\hline direct combined savings [\%] & 8 & 6 & 8 & 6 & 8 & 6 & -6 & -9 & 4 & 4 \\
\hline indirect savings [\%] & 2 & 2 & 2 & 2 & 2 & 2 & -1 & -5 & 3 & 3 \\
\hline direct \& indirect savings [\%] & 10 & 11 & 9 & 11 & 10 & 11 & -8 & -14 & 8 & 7 \\
\hline \multicolumn{11}{|l|}{ retail } \\
\hline base expenditure \& demand & 973 & 444 & 976 & 444 & 963 & 444 & 10 & 0 & 5.09 & 2.60 \\
\hline direct shade tree savings [\%] & 4 & 5 & 4 & 5 & 4 & 5 & 0 & 0 & 2 & 2 \\
\hline direct high albedo savings [\%] & 8 & 6 & 7 & 6 & 8 & 6 & -13 & 0 & 7 & 7 \\
\hline direct combined savings [\%] & 12 & 10 & 12 & 10 & 12 & 10 & -20 & 0 & 9 & 11 \\
\hline indirect savings [\%] & 1 & 2 & 1 & 2 & 1 & 2 & -3 & 0 & 2 & 2 \\
\hline direct \& indirect savings [\%] & 14 & 12 & 14 & 12 & 15 & 12 & -20 & 0 & 11 & 12 \\
\hline
\end{tabular}

a Base energy expenditures and peak power demand are calculated for buildings without shade trees and with a dark roof (albedo 0.2). Direct savings are determined for buildings with 8 shade trees (retail 4) and a high-albedo roof (residential 0.5 and commercial 0.6 ). To estimate direct savings for other changes in albedo $(\Delta \mathrm{a})$ multiply the savings by the ratio $\Delta \mathrm{a} / 0.3$ for residences and $\Delta \mathrm{a} / 0.4$ for commercial buildings.

b Combined HIR effects are not precisely the sum of individual effects. 
Table 8.2(a). Sacramento simulated cooling and heating annual base energy expenditures and savings [ $\left.\$ / 1000 \mathrm{ft}^{2}\right]$, and peak power demand and savings $\left[\mathrm{kW} / 1000 \mathrm{ft}^{2}\right]$ from Heat Island Reduction (HIR) strategies for residential and commercial buildings. Direct savings are from the strategic placement of shade trees and the use of high-albedo roofs on individual buildings, and indirect savings include the impact of reduced air temperature from urban reforestation and high-albedo surfaces.

\begin{tabular}{|c|c|c|c|c|c|c|c|c|c|c|}
\hline \multirow{2}{*}{$\begin{array}{c}\text { building type } \\
\qquad \& \\
\text { HIR strategy }\end{array}$} & \multicolumn{4}{|c|}{ annual total energy } & \multicolumn{2}{|c|}{$\begin{array}{c}\text { annual electricity } \\
\text { gas heat }\end{array}$} & \multicolumn{2}{|c|}{$\begin{array}{l}\text { annual gas } \\
\text { gas heat }\end{array}$} & \multicolumn{2}{|c|}{$\begin{array}{c}\text { peak power } \\
\text { gas \& electric heat }\end{array}$} \\
\hline & -1979 & $1980+$ & -1979 & $1980+$ & -1979 & $1980+$ & -1979 & $1980+$ & -1979 & $1980+$ \\
\hline residence & & & & & & & & & & \\
\hline base expenditure \& demand & 404 & 170 & 658 & 227 & 166 & 75 & 238 & 95 & 3.58 & 1.97 \\
\hline direct shade tree savings & 8 & 6 & 7 & 5 & 32 & 15 & -24 & -9 & 0.27 & 0.18 \\
\hline direct high albedo savings & 19 & 8 & 8 & 5 & 27 & 11 & -8 & -3 & 0.25 & 0.12 \\
\hline direct combined savings & 24 & 15 & 15 & 9 & 57 & 28 & -33 & -13 & 0.57 & 0.32 \\
\hline indirect savings & 7 & 4 & 4 & 3 & 15 & 7 & -8 & -3 & 0.16 & 0.09 \\
\hline direct $\&$ indirect savings & 24 & 16 & 19 & 12 & 68 & 33 & -44 & -17 & 0.74 & 0.43 \\
\hline office & & & & & & & & & & \\
\hline base expenditure \& demand & 974 & 440 & 1009 & 445 & 874 & 420 & 100 & 20 & 7.84 & 4.22 \\
\hline direct shade tree savings & 71 & 31 & 71 & 31 & 72 & 31 & -1 & 0 & 0.41 & 0.16 \\
\hline direct high albedo savings & 58 & 17 & 57 & 17 & 63 & 18 & -5 & -1 & 0.41 & 0.14 \\
\hline direct combined savings & 129 & 47 & 128 & 47 & 134 & 49 & -5 & -2 & 0.83 & 0.32 \\
\hline indirect savings & 34 & 19 & 35 & 19 & 35 & 19 & -1 & 0 & 0.35 & 0.17 \\
\hline direct \& indirect savings & 160 & 66 & 160 & 64 & 166 & 68 & -6 & -2 & 1.16 & 0.48 \\
\hline retail & & & & & & & & & & \\
\hline base expenditure \& demand & 1036 & 406 & 1043 & 406 & 1018 & 406 & 18 & 0 & 5.87 & 2.96 \\
\hline direct shade tree savings & 71 & 35 & 71 & 35 & 71 & 35 & 0 & 0 & 0.30 & 0.21 \\
\hline direct high albedo savings & 89 & 27 & 89 & 26 & 91 & 27 & -2 & 0 & 0.43 & 0.18 \\
\hline direct combined savings & 164 & 62 & 164 & 62 & 166 & 62 & -2 & 0 & 0.77 & 0.48 \\
\hline indirect savings & 26 & 16 & 26 & 16 & 26 & 16 & 0 & 0 & 0.18 & 0.09 \\
\hline direct $\&$ indirect savings & 188 & 76 & 188 & 76 & 190 & 76 & -2 & 0 & 0.96 & 0.57 \\
\hline
\end{tabular}

a Base energy expenditures and peak power demand are calculated for buildings without shade trees and with a dark roof (albedo 0.2). Direct savings are determined for buildings with 8 shade trees (retail 4) and a high-albedo roof (residential 0.5 and commercial 0.6). To estimate direct savings for other changes in albedo $(\Delta \mathrm{a})$ multiply the savings by the ratio $\Delta \mathrm{a} / 0.3$ for residences and $\Delta \mathrm{a} / 0.4$ for commercial buildings.

b Combined HIR effects are not precisely the sum of individual effects. 
Table 8.2(b). Sacramento simulated cooling and heating annual base energy expenditures $\left[\$ / 1000 \mathrm{ft}^{2}\right]$ and savings [\%], and peak power demand $\left[\mathrm{kW} / 1000 \mathrm{ft}^{2}\right]$ and savings [\%] from Heat Island Reduction (HIR) strategies for residential and commercial buildings. Direct savings are from the strategic placement of shade trees and the use of high-albedo roofs on individual buildings, and indirect savings include the impact of reduced air temperature from urban reforestation and high-albedo surfaces.

\begin{tabular}{|c|c|c|c|c|c|c|c|c|c|c|}
\hline \multirow{3}{*}{$\begin{array}{l}\text { building type } \\
\qquad \& \\
\text { HIR strategy }\end{array}$} & \multicolumn{4}{|c|}{ annual total energy } & \multirow{2}{*}{\multicolumn{2}{|c|}{$\begin{array}{c}\text { annual electricity } \\
\text { gas heat }\end{array}$}} & \multirow{2}{*}{\multicolumn{2}{|c|}{$\begin{array}{l}\text { annual gas } \\
\text { gas heat }\end{array}$}} & \multirow{2}{*}{\multicolumn{2}{|c|}{$\begin{array}{c}\text { peak power } \\
\text { gas \& electric heat }\end{array}$}} \\
\hline & \multicolumn{2}{|c|}{ gas heat } & \multicolumn{2}{|c|}{ electric heat } & & & & & & \\
\hline & -1979 & $1980+$ & -1979 & $1980_{+}^{+}$ & -1979 & $1980+$ & -1979 & $1980+$ & -1979 & $1980+$ \\
\hline \multicolumn{11}{|l|}{ residence } \\
\hline base expenditure \& demand & 404 & 170 & 658 & 227 & 166 & 75 & 238 & 95 & 3.58 & 1.97 \\
\hline direct shade tree savings [\%] & 2 & 4 & 1 & 2 & 19 & 20 & -10 & -10 & 7 & 9 \\
\hline direct high albedo savings [\%] & 5 & 5 & 1 & 2 & 17 & 14 & -3 & -3 & 7 & 6 \\
\hline direct combined savings [\%] & 6 & 9 & 2 & 4 & 34 & 37 & -14 & -13 & 16 & 16 \\
\hline indirect savings [\%] & 2 & 3 & 1 & 1 & 9 & 9 & -3 & -3 & 4 & 4 \\
\hline direct $\&$ indirect savings $[\%]$ & 6 & 10 & 3 & 5 & 41 & 44 & -19 & -18 & 21 & 22 \\
\hline \multicolumn{11}{|l|}{ office } \\
\hline base expenditure $\&$ demand & 974 & 440 & 1009 & 445 & 874 & 420 & 100 & 20 & 7.84 & 4.22 \\
\hline direct shade tree savings [\%] & 7 & 7 & 7 & 7 & 8 & 7 & -1 & 0 & 5 & 4 \\
\hline direct high albedo savings [\%] & 6 & 4 & 6 & 4 & 7 & 4 & -5 & -5 & 5 & 3 \\
\hline direct combined savings [\%] & 13 & 11 & 13 & 11 & 15 & 12 & -5 & -10 & 11 & 7 \\
\hline indirect savings [\%] & 3 & 4 & 3 & 4 & 4 & 5 & -1 & 0 & 4 & 4 \\
\hline direct \& indirect savings [\%] & 16 & 15 & 16 & 14 & 19 & 16 & -6 & -10 & 15 & 11 \\
\hline \multicolumn{11}{|l|}{ retail } \\
\hline base expenditure \& demand & 1036 & 406 & 1043 & 406 & 1018 & 406 & 18 & 0 & 5.87 & 2.96 \\
\hline direct shade tree savings [\%] & 7 & 9 & 7 & 9 & 7 & 9 & 0 & 0 & 5 & 7 \\
\hline direct high albedo savings [\%] & 9 & 7 & 9 & 6 & 9 & 7 & -11 & 0 & 7 & 6 \\
\hline direct combined savings [\%] & 16 & 15 & 16 & 15 & 16 & 15 & -11 & 0 & 13 & 16 \\
\hline indirect savings [\%] & 2 & 4 & 2 & 4 & 3 & 4 & 0 & 0 & 3 & 3 \\
\hline direct \& indirect savings [\%] & 18 & 19 & 18 & 19 & 19 & 19 & -11 & 0 & 16 & 19 \\
\hline
\end{tabular}

a Base energy expenditures and peak power demand are calculated for buildings without shade trees and with a dark roof (albedo 0.2). Direct savings are determined for buildings with 8 shade trees (retail 4) and a high-albedo roof (residential 0.5 and commercial 0.6 ). To estimate direct savings for other changes in albedo $(\Delta \mathrm{a})$ multiply the savings by the ratio $\Delta \mathrm{a} / 0.3$ for residences and $\Delta \mathrm{a} / 0.4$ for commercial buildings.

b Combined HIR effects are not precisely the sum of individual effects. 
Table 8.3(a). Salt Lake City simulated cooling and heating annual base energy expenditures and savings [ $\$ / 1000 \mathrm{ft}^{2}$ ], and peak power demand and savings [kW/1000 $\left.\mathrm{ft}^{2}\right]$ from Heat Island Reduction (HIR) strategies for residential and commercial buildings. Direct savings are from the strategic placement of shade trees and the use of high-albedo roofs on individual buildings, and indirect savings include the impact of reduced air temperature from urban reforestation and high-albedo surfaces.

\begin{tabular}{|c|c|c|c|c|c|c|c|c|c|c|}
\hline \multirow{2}{*}{$\begin{array}{c}\text { building type } \\
\text { \& } \\
\text { HIR strategy }\end{array}$} & \multicolumn{4}{|c|}{ annual total energy } & \multicolumn{2}{|c|}{$\begin{array}{c}\text { annual electricity } \\
\text { gas heat }\end{array}$} & \multicolumn{2}{|c|}{$\begin{array}{c}\text { annual gas } \\
\text { gas heat }\end{array}$} & \multicolumn{2}{|c|}{$\begin{array}{c}\text { peak power } \\
\text { gas \& electric heat }\end{array}$} \\
\hline & -1979 & $1980+$ & -1979 & $1980+$ & -1979 & $1980+$ & -1979 & $1980+$ & -1979 & $1980+$ \\
\hline residence & & & & & & & & & & \\
\hline base expenditure \& demand & 610 & 270 & 1033 & 446 & 176 & 84 & 434 & 186 & 3.51 & 1.89 \\
\hline direct shade tree savings & -7 & 1 & 32 & 11 & 21 & 13 & -28 & -12 & 0.23 & 0.15 \\
\hline direct high albedo savings & 9 & 2 & -5 & -2 & 19 & 8 & -10 & -6 & 0.28 & 0.12 \\
\hline direct combined savings & 2 & 3 & 23 & 8 & 39 & 19 & -37 & -16 & 0.51 & 0.26 \\
\hline indirect savings & 1 & 2 & 19 & 3 & 12 & 6 & -11 & -4 & 0.15 & 0.08 \\
\hline direct $\&$ indirect savings & 3 & 4 & 30 & 11 & 49 & 24 & -46 & -20 & 0.66 & 0.34 \\
\hline office & & & & & & & & & & \\
\hline base expenditure \& demand & 638 & 308 & 756 & 348 & 494 & 254 & 144 & 54 & 7.32 & 4.02 \\
\hline direct shade tree savings & 46 & 24 & 48 & 22 & 47 & 25 & -1 & -1 & 0.52 & 0.35 \\
\hline direct high albedo savings & 29 & 8 & 26 & 6 & 34 & 11 & -5 & -3 & 0.35 & 0.14 \\
\hline direct combined savings & 74 & 31 & 73 & 29 & 80 & 35 & -6 & -4 & 0.83 & 0.49 . \\
\hline indirect savings & 20 & 11 & 18 & 9 & 22 & 12 & -2 & -1 & 0.36 & 0.18 \\
\hline direct \& indirect savings & 94 & 41 & 91 & 37 & 101 & 46 & -7 & -5 & 1.19 & 0.67 \\
\hline retail & & & & & & & & & & \\
\hline base expenditure \& demand & 600 & 241 & 635 & 243 & 563 & 239 & 37 & 2 & 5.04 & 2.51 \\
\hline direct shade tree savings & 39 & 21 & 38 & 22 & 39 & 21 & 0 & 0 & 0.23 & 0.18 \\
\hline direct high albedo savings & 48 & 13 & 45 & 14 & 51 & 14 & -3 & -1 & 0.34 & 0.12 \\
\hline direct combined savings & 91 & 35 & 88 & 35 & 94 & 36 & -3 & -1 & 0.64 & 0.31 \\
\hline indirect savings & 17 & 9 & 15 & 10 & 17 & 9 & 0 & $\hat{0}$ & 0.14 & 0.07 \\
\hline direct \& indirect savings & 107 & 43 & 103 & 43 & 110 & 45 & -3 & -2 & 0.77 & 0.38 \\
\hline
\end{tabular}

a Base energy expenditures and peak power demand are calculated for buildings without shade trees and with a dark roof (albedo 0.2). Direct savings are determined for buildings with 8 shade trees (retail 4) and a high-albedo roof (residential 0.5 and commercial 0.6). To estimate direct savings for other changes in albedo $(\Delta \mathrm{a})$ multiply the savings by the ratio $\Delta \mathrm{a} / 0.3$ for residences and $\Delta \mathrm{a} / 0.4$ for commercial buildings.

b Combined HIR effects are not precisely the sum of individual effects. 
Table 8.3(b). Salt Lake City simulated cooling and heating annual base energy expenditures [ $\left.\$ / 1000 \mathrm{ft}^{2}\right]$ and savings [\%], and peak power demand $\left[\mathrm{kW} / 1000 \mathrm{ft}^{2}\right]$ and savings [\%] from Heat Island Reduction (HIR) strategies for residential and commercial buildings. Direct savings are from the strategic placement of shade trees and the use of high-albedo roofs on individual buildings, and indirect savings include the impact of reduced air temperature from urban reforestation and high-albedo surfaces.

\begin{tabular}{|c|c|c|c|c|c|c|c|c|c|c|}
\hline \multirow{3}{*}{$\begin{array}{l}\text { building type } \\
\qquad \& \\
\text { HIR strategy }\end{array}$} & \multicolumn{4}{|c|}{ annual total energy } & \multirow{2}{*}{\multicolumn{2}{|c|}{$\begin{array}{c}\text { annual electricity } \\
\text { gas heat }\end{array}$}} & \multirow{2}{*}{\multicolumn{2}{|c|}{$\begin{array}{l}\text { annual gas } \\
\text { gas heat }\end{array}$}} & \multirow{2}{*}{\multicolumn{2}{|c|}{$\begin{array}{c}\text { peak power } \\
\text { gas \& electric heat }\end{array}$}} \\
\hline & \multicolumn{2}{|c|}{ gas heat } & \multicolumn{2}{|c|}{ electric heat } & & & & & & \\
\hline & -1979 & $1980+$ & -1979 & $1980+$ & -1979 & $1980+$ & -1979 & $1980+$ & -1979 & $1980+$ \\
\hline residence & & & & & & & & & & \\
\hline base expenditure $\&$ demand & 610 & 270 & 1033 & 446 & 176 & 84 & 434 & 186 & 3.51 & 1.89 \\
\hline direct shade tree savings [\%] & -1 & 0 & 3 & 2 & 12 & 15 & -7 & -6 & 7 & 8 \\
\hline direct high albedo savings [\%] & 1 & 1 & -1 & 0 & 11 & 9 & -2 & -3 & 8 & 6 \\
\hline direct combined savings [\%] & 0 & 1 & 2 & 2 & 22 & 23 & -9 & -9 & 14 & 14 \\
\hline indirect savings [\%] & 0 & 1 & 2 & 1 & 7 & 7 & -3 & -2 & 4 & 4 \\
\hline direct \& indirect savings [\%] & 0 & 1 & 3 & 3 & 28 & 28 & -11 & -11 & 19 & 18 \\
\hline office & & & & & & & & & & \\
\hline base expenditure \& demand & 638 & 308 & 756 & 348 & 494 & 254 & 144 & 54 & 7.32 & 4.02 \\
\hline direct shade tree savings [\%] & 7 & 8 & 6 & 6 & 10 & 10 & 0 & -3 & 7 & 9 \\
\hline direct high albedo savings [\%] & 5 & 2 & 3 & 2 & 7 & 4 & -3 & -6 & 5 & 3 \\
\hline direct combined savings [\%] & 12 & 10 & 10 & 8 & 16 & 14 & -4 & -7 & 11 & 12 \\
\hline indirect savings [\%] & 3 & 3 & 2 & 3 & 4 & 5 & -1 & -2 & 5 & 5 \\
\hline direct \& indirect savings [\%] & 15 & 13 & 12 & 11 & 20 & 18 & -5 & -10 & 16 & 17 \\
\hline retail & & & & & & & & & & \\
\hline base expenditure \& demand & 600 & 241 & 635 & 243 & 563 & 239 & 37 & 2 & 5.04 & 2.51 \\
\hline direct shade tree savings [\%] & 6 & 9 & 6 & 9 & 7 & 9 & -3 & 0 & 5 & 7 \\
\hline direct high albedo savings [\%] & 8 & 6 & 7 & 6 & 9 & 6 & -24 & -50 & 7 & 5 \\
\hline direct combined savings [\%] & 15 & 14 & 14 & 14 & 17 & 15 & -24 & -50 & 13 & 12 \\
\hline indirect savings [\%] & 3 & 4 & 2 & 4 & 3 & 4 & -3 & 0 & 3 & 3 \\
\hline direct \& indirect savings [\%] & 18 & 18 & 16 & 18 & 20 & 19 & -24 & -100 & 15 & 15 \\
\hline
\end{tabular}

a Base energy expenditures and peak power demand are calculated for buildings without shade trees and with a dark roof (albedo 0.2). Direct savings are determined for buildings with 8 shade trees (retail 4) and a high-albedo roof (residential 0.5 and commercial 0.6 ). To estimate direct savings for other changes in albedo $(\Delta \mathrm{a})$ multiply the savings by the ratio $\Delta \mathrm{a} / 0.3$ for residences and $\Delta \mathrm{a} / 0.4$ for commercial buildings.

b Combined HIR effects are not precisely the sum of individual effects. 


\section{Calculation of Air-Conditioned Roof Area}

The stock of residential, office and retail buildings with air-conditioning $(\mathrm{a} / \mathrm{c})$ were estimated for both old and new construction and both gas furnace and electric heat pump using an algorithm that can readily be applied to any US Metropolitan Statistical Area (MSA).

\section{Residential}

The total roof area for residential buildings with a/c in each city were calculated by multiplying the number of houses [hu] in each city by the average roof area $\left[\mathrm{ft}^{2} / \mathrm{hu}\right.$ ] for the residential buildings and the saturation [fraction] of air-conditioned residences (see EQ. 1).

total residential a/c roof area $\left[f t^{2}\right]=[h u] *\left[f t^{2} / h u\right] * a / c$ saturation

Number of Housing Units [hu]: These data were obtained from the US Census (1990) listed by year of construction and summarized for buildings built prior to 1980 (designated as -1979 in text and tables) and 1980-1990 (1980+). See row 1 in Table 9.1.

Average Residential Roof Area [ $\mathrm{ft}^{2} / \mathrm{hu}$ ]: These data were not readily available for each city and were estimated from a previous analysis performed for residential and commercial buildings in eleven US MSAs (Konopacki et al. 1997). In that study, it was determined that MSAs and roof area can be categorized into one of three levels of general building height: high-rise such as New York City (4.5 fls/hu), medium-rise like Chicago $(3.1 \mathrm{fls} / \mathrm{hu})$ and Washington DC (3.0 fls/hu), and low-rise like New Orleans and Phoenix (1.5 fls/hu). Data obtained from the American Housing Survey (AHS) showed that Sacramento had 1.4 fls/hu and Salt Lake City had 2.1 $\mathrm{fls} / \mathrm{hu}$. In general, these are cities with low-rise buildings comparable to New Orleans and Phoenix each with $1.5 \mathrm{fls} / \mathrm{hu}$. See row 3 in Table 9.1 .

In order to obtain average roof area per house in each city, we first estimated the average floor area per house in each city. We assumed that the average floor area for Baton Rouge is the same as New Orleans, and for Sacramento and Salt Lake City is the average of New Orleans and Phoenix (weighted by total roof area in New Orleans and Phoenix ${ }^{7}$ ). See row 2 in Table 9.1. Then, we calculated the average roof area for each city by dividing the average floor area (row 2 ) by the average number of floors per housing unit (row 3). The estimated average roof area for each city is listed on row 4.

Total Residential Roof Area [ $\left.\mathrm{ft}^{2}\right]$ : Calculated by combining the number of housing units and the average roof area. See row 5 in Table 9.1.

Residential A/C Saturation [\%]: The saturation of air-conditioning and heating equipment were identified from Konopacki et al. (1997) and AHS (1997, 1997 \& 1994). Residential a/c saturation spanned $85-95 \%$ across constructions and cities. The exception was old constructions in Salt Lake City which was only $21 \%$. In general, electric heat pump saturation was low in comparison to gas. See row 6 in Table 9.1.

7 US Census data (1990) show that New Orleans is an older city with $82 \%$ of residential buildings built prior to 1980 , Phoenix is a modern city with only $60 \%$ built before 1980 , and Sacramento and Salt Lake City are in the middle of that range with $71 \%$ and $76 \%$, respectively. 
Table 9.1. Calculation of air-conditioned roof area $\left[\mathrm{Mft}^{2}\right]$ for residential and commercial buildings in the Metropolitan Statistical Areas of Baton Rouge, Sacramento and Salt Lake City.

\begin{tabular}{|c|c|c|c|c|c|c|c|c|c|}
\hline & \multicolumn{3}{|c|}{ Baton Rouge, LA. } & \multicolumn{3}{|c|}{ Sacramento, CA. } & \multicolumn{3}{|c|}{ Salt Lake City, UT. } \\
\hline & -1979 & $1980+$ & total & -1979 & $1980+$ & total & -1979 & $1980+$ & total \\
\hline $\begin{array}{l}1990 \text { US Census } \\
\text { persons }[1000 \mathrm{~s}]\end{array}$ & - & - & 528 & - & - & 1481 & - & - & 1072 \\
\hline $\begin{array}{l}\text { 1) housing units [1000s] } \\
\text { residence }\end{array}$ & 156 & 56 & 212 & 435 & 175 & 610 & 283 & 88 & 371 \\
\hline 2) average floor area $\left[\mathrm{ft}^{2} / \mathrm{hu}\right]^{\mathrm{a}}$ & 1545 & 2672 & - & 1604 & 1895 & - & 1604 & 1895 & - \\
\hline 3) building height [fls/hu $]^{\mathrm{b}}$ & - & - & 1.5 & - & - & 1.4 & - & - & 2.1 \\
\hline 4) average roof area $\left[\mathrm{ft}^{2} / \mathrm{hu}\right]$ & 1030 & 1781 & - & 1145 & 1353 & - & 764 & 902 & - \\
\hline 5) total roof area $\left[\mathrm{Mft}^{2}\right]$ & 161 & 100 & 261 & 498 & 237 & 735 & 216 & 79 & 295 \\
\hline 6) equipment saturation $[\%]^{a}$ & & & & & & & & & \\
\hline gas furnace & 97 & 86 & - & 89 & 83 & - & 99 & 99 & - \\
\hline electric heat pump & 3 & 14 & - & 11 & 17 & $13^{b}$ & 1 & 1 & $1^{b}$ \\
\hline air conditioner & 93 & 95 & $94^{\mathrm{b}}$ & 85 & 95 & $88^{\mathrm{b}}$ & 21 & 95 & $41^{b}$ \\
\hline 7) $\mathrm{a} / \mathrm{c}$ roof area $\left[\mathrm{Mft}^{2}\right]$ & & & & & & & & & \\
\hline w/ gas furnace & 145 & 82 & 227 & 377 & 187 & 564 & 45 & 74 & 119 \\
\hline w/ heat pump & 5 & 13 & 18 & 46 & 38 & 84 & $\mathbf{0}$ & 1 & 1 \\
\hline total & 150 & 95 & 245 & 423 & 225 & 648 & 45 & 75 & 120 \\
\hline office & & & & & & & & & \\
\hline 8) roof area fraction [\% row 5$]^{a}$ & 4 & 7 & - & 4 & 7 & - & 4 & 7 & - \\
\hline 9) total roof area $\left[\mathrm{Mft}^{2}\right]$ & 6 & 7 & 13 & 20 & 17 & 37 & 9 & 6 & 15 \\
\hline 10) equipment saturation $[\%]^{2}$ & & & & & & & & & \\
\hline gas furnace & 95 & 85 & - & 90 & 85 & - & 99 & 99 & - \\
\hline electric heat pump & 5 & 15 & - & 10 & 15 & - & 1 & 1 & - \\
\hline air conditioner & 100 & 100 & - & 100 & 100 & - & 100 & 100 & - \\
\hline 11) $\mathrm{a} / \mathrm{c}$ roof area $\left[\mathrm{Mft}^{2}\right]$ & & & & & & & & & \\
\hline w/ gas furnace & 6 & 6 & 12 & 18 & 14 & 32 & 9 & 6 & 15 \\
\hline w/ heat pump & $\mathbf{0}$ & 1 & 1 & 2 & 3 & 5 & $\mathbf{0}$ & $\mathbf{0}$ & 0 \\
\hline total & 6 & 7 & 13 & 20 & 17 & 37 & 9 & 6 & 15 \\
\hline retail store & & & & & & & & & \\
\hline 8) roof area fraction $[\% \text { row } 5]^{\mathrm{a}}$ & 10 & 5 & - & 10 & 5 & - & 10 & 5 & - \\
\hline 9) total roof area $\left[\mathrm{Mft}^{2}\right]$ & 16 & 5 & 21 & 50 & 12 & 62 & 22 & 4 & 26 \\
\hline 10) equipment saturation $[\%]^{a}$ & & & & & & & & & \\
\hline gas furnace & 95 & 100 & - & 95 & 92 & - & 99 & 99 & - \\
\hline electric heat pump & 5 & 0 & - & 5 & 8 & - & 1 & 1 & - \\
\hline air conditioner & 85 & 79 & - & 82 & 75 & - & 82 & 75 & - \\
\hline 11) $\mathrm{a} / \mathrm{c}$ roof area $\left[\mathrm{Mft}^{2}\right]$ & & & & & & & & & \\
\hline w/ gas furnace & 13 & 4 & 17 & 39 & 8 & 47 & 18 & 3 & 21 \\
\hline$w /$ heat pump & 1 & 0 & 1 & 2 & 1 & 3 & 0 & 0 & 0 \\
\hline total & 14 & 4 & 18 & 41 & 9 & 50 & 18 & 3 & 21 \\
\hline
\end{tabular}

a Konopacki, S. et al. 1997. "Cooling Energy Savings Potential of Light-Colored Roofs for Residential and Commercial Buildings in 11 US Metropolitan Areas". Lawrence Berkeley National Laboratory Report LBNL-39433.

b AHS. 1997, 1997 \& 1994. "American Housing Survey for the [New Orleans, Sacramento \& Salt Lake City] Metropolitan Area in (1995, 1996 \& 1992)". 
Total Residential A/C Roof Area [ $\mathrm{ft}^{2}$ ]: This was calculated by combining the residential roof area with the a/c equipment saturation. Residences accounted for $89 \%$ (245 $\left.\mathrm{Mft}^{2}\right)$ of the total air-conditioned roof area in Baton Rouge, 88\% (648 $\left.\mathrm{Mft}^{2}\right)$ in Sacramento and $77 \%\left(120 \mathrm{Mft}^{2}\right)$ in Salt Lake City. Residences built prior to 1980 accounted for the majority of the air-conditioned roof area in each city with the exception of those in Salt Lake City, due to low saturation. See row 7 in Table 9.1.

\section{Commercial}

For the commercial buildings simulated in this study (office and retail) we estimated the total roof area by using the stock of residential buildings as a guideline. Konopacki et al. (1997) found that the ratio of roof area for commercial buildings to those of the residential buildings for low-rise (Baton Rouge, Sacramento and Salt Lake City are low-rise) cities to be 0.21 (New Orleans was 0.21 ). This ratio compares favorably with the value calculated for the entire United States (0.20) using data from CBECS (1995) and RECS (1992) as shown in Table 9.2. Observing that the national ratio of commercial to residential roof area and the average low-rise value from Konopacki et al. (1997) were in agreement, we incorporated from Konopacki et al. (1997) fractional roof area $(f)$ for old (4\%) and new (7\%) offices and old $(10 \%)$ and new (5\%) retail stores (see row 8 in Table 9.1). Then, a similar approach to that of the residential buildings was used to calculate the total roof area for the air-conditioned commercial buildings (see EQ. 2).

total commercial a/c roof area $\left[f t^{2}\right]=$ total residential roof area $\left[f t^{2}\right] *[f] *$ a/c saturation [2]

Total Residential Roof Area [ft ${ }^{2}$ : Calculated above. See row 5 in Table 9.1.

Fraction of Commercial Roof Area to Residential Roof Area [f]: See row 8 in Table 9.1.

Total Commercial Roof Area $\left[\mathrm{ft}^{2}\right]$ : Calculated by combining the total residential roof area with the commercial to residential roof area fraction [f]. See row 9 in Table 9.1.

Commercial A/C Saturation [\%]: The saturation of air-conditioning and heating equipment were identified from Konopacki et al. (1997). For office buildings, a/c saturation was $100 \%$ for old and new constructions in each pilot city, and for retail stores it ranged from $75-85 \%$. In general, electric heat pump saturation was low in comparison to gas. See row 10 in Table 9.1.

Total Commercial A/C Roof Area [ft $\left.{ }^{2}\right]$ : Calculated by combining the total commercial roof area with the $\mathrm{a} / \mathrm{c}$ equipment saturation. Offices accounted for $5 \%\left(13 \mathrm{Mft}^{2}\right)$ and retail stores for $6 \%\left(18 \mathrm{Mft}^{2}\right)$ of the total air-conditioned roof area in Baton Rouge, offices $5 \%\left(37 \mathrm{Mft}^{2}\right)$ and retail stores $7 \%\left(50 \mathrm{Mft}^{2}\right)$ in Sacramento, and offices $10 \%\left(15 \mathrm{Mft}^{2}\right)$ and retail stores $13 \%(21$ $\mathrm{Mft}^{2}$ ) in Salt Lake City. See row 11 in Table 9.1.

Table 9.2. Estimates of commercial and residential building roof area.

\begin{tabular}{|c||cc||cc||cc|}
\hline \multicolumn{1}{|c||}{ source $\rightarrow$} & \multicolumn{2}{|c||}{ Konopacki et al. (1997) } & \multicolumn{2}{c|}{ United States: RECS (1992) \& CBECS (1995) } \\
\hline \hline $\begin{array}{c}\text { building } \\
\text { sector }\end{array}$ & \multicolumn{2}{|c|}{ ratio of roof area [com/res] } & floor area & floors & \multicolumn{2}{c|}{ roof area } \\
low-rise avg. & New Orleans & {$\left[\mathrm{Bft}^{2}\right]$} & [com/res] \\
\hline \hline residential & & & 144.4 & 1.5 & 96.27 & \\
commercial & 0.21 & 0.21 & 58.78 & 3.0 & 19.59 & 0.20 \\
\hline
\end{tabular}

RECS (1992) adjusted from 94.0 M households and CBECS (1995) with $4.58 \mathrm{M}$ buildings. 


\section{Metropolitan-Wide Impact of Heat Island Reduction Strategies}

The potential metropolitan-wide benefits of Heat Island Reduction (HIR) strategies (i.e., shade trees, reflective roofs, reflective pavements and urban vegetation) for residential, office and retail buildings with air-conditioning are estimated in the forms of annual energy savings, annual electricity savings, annual natural gas deficit, peak power avoided and annual carbon reduction. Note, the following points should be considered upon examination of these results.

- Base energy expenditures and peak power demand are calculated for buildings without shade trees and with a dark roof (albedo 0.2), and direct savings are determined for buildings with 8 shade trees (retail 4) and a high-albedo roof (residential 0.5 and commercial $0.6)$.

- Combined HIR effects are not precisely the sum of individual effects.

- The conversion from BWh to carbon is for the US mix of electricity, in 1995, DOE/EIA0383(97) (EIA 1997) shows that $3000 \mathrm{BkWh}$ sold emitted 500MtC (million metric tons of carbon), thus $1 \mathrm{BWh}$ emits $0.167 \mathrm{ktC}$.

Metropolitan-wide estimates of annual energy savings [1000\$] and avoided peak power [MW] were calculated for residences, office buildings and retail stores in the three pilot cities through modeling the impact of HIR strategies. The analysis is performed to quantify the impact of:

1. strategically-placed shade trees near building [direct effect]

2. use of high-albedo roofing material on building [direct effect]

3. combined strategies 1 and 2 [direct effect]

4. urban reforestation with high-reflective pavements and building surfaces [indirect effect]

5. combined strategies 1,2 and 4 [direct and indirect effects].

The metropolitan-wide results were obtained by combining the simulated energy and power savings from HIR strategies by the total air-conditioned roof area for each building type in the city. These results are presented in Tables 10.1(a),10.2(a),10.3(a) for each prototype by vintage and system type (i.e., for old and new building constructions and for gas and electric heat). Metropolitan-wide annual energy savings [M\$], annual electricity savings [BWh \& M\$], annual natural gas deficit [Mtherms \& M\$], peak power avoided [MW] and annual carbon reduction [kt] are presented in Tables 10.1(b),10.2(b),10.3(b) for residences, office buildings, retail stores and the total for each HIR strategy and pilot city. The level of carbon $\left(\right.$ as $\left.\mathrm{CO}_{2}\right)$ emitted as a consequence of electricity production should decrease with demand lessening from implementation of HIR strategies. On an annualized basis $1 \mathrm{BWh}$ of electricity emits $0.167 \mathrm{kt}$ (1000 metric tons) of carbon (EIA 1997) ${ }^{8}$.

Baton Rouge is a metropolitan area of over 0.5 million persons and is situated inland, in southeastern Louisiana, where the climate is hot and humid with an April through October cooling season. Most residential buildings are one story and commercial buildings are low-rises. The saturation of air conditioning is high in both residential and commercial buildings. The total roof area of residential, office and retail buildings with air-conditioning is $245 \mathrm{Mft}^{2}, 13$ and 18 ,

8 The conversion from BWh to carbon is for the US mix of electricity. In 1995, DOE/EIA-0383(97) (EIA 1997) shows that $3000 \mathrm{BkWh}$ sold emitted $500 \mathrm{MtC}$ (million metric tons of carbon), thus $1 \mathrm{BWh}$ emits $0.167 \mathrm{ktC}$. 
respectively. Annual electricity savings of $\$ 18 \mathrm{M}$ less a $17 \%$ natural gas deficit combine for a potential rate-payer benefit of $\$ 15 \mathrm{M}$ (79\% residence, $6 \%$ office and $15 \%$ retail) in total annual energy savings from the combined direct and indirect (15\%) effects of HIR strategies. Additionally, peak power avoidance is estimated at $133 \mathrm{MW}(89 \%, 4 \%$ and $7 \%)$ and the reduction in annual carbon emissions at $41 \mathrm{kt}(82 \%, 5 \%$ and $13 \%)$.

Sacramento is a metropolitan area of almost 1.5 million persons and is situated inland, in the central valley of northern California, where the climate is hot and dry with a cooling season lasting from May through September. Most residential buildings are one story and commercial buildings are low-rises. The saturation of air conditioning is high in both residential and commercial buildings. The total roof area of residential, office and retail buildings with airconditioning is $648 \mathrm{Mft}^{2}, 37$ and 50 , respectively. Annual electricity savings of $\$ 46 \mathrm{M}$ less a $43 \%$ natural gas deficit combine for a potential rate-payer benefit of $\$ 26 \mathrm{M}$ (51\% residence, $17 \%$ office and $32 \%$ retail) in total annual energy savings from the combined direct and indirect $(23 \%)$ effects of HIR strategies. Additionally, peak power avoidance is estimated at $486 \mathrm{MW}$ $(84 \%, 7 \%$ and $9 \%)$ and the reduction in annual carbon at $92 \mathrm{kt}(72 \%, 10 \%$ and $18 \%)$.

Salt Lake City is a metropolitan area of nearly 1.1 million persons and is situated inland, in the high-desert terrain of northwestern Utah, where the climate is hot and dry during the June through September cooling season, and cold with a long heating season beginning in September and ending in May. Most residential buildings are one story and commercial buildings are lowrises. The saturation of air conditioning is high in both residential (except in the older residences) and commercial buildings. The total roof area of residential, office and retail buildings with air-conditioning is $120 \mathrm{Mft}^{2}, 15$ and 21 , respectively. Annual electricity savings of $\$ 7 \mathrm{M}$ less a $51 \%$ natural gas deficit combine for a potential rate-payer benefit of $\$ 4 \mathrm{M}(11 \%$ residence, $31 \%$ office and $58 \%$ retail) in total annual energy savings from the combined direct and indirect $(22 \%)$ effects of HIR strategies. Additionally, peak power avoidance is estimated at $85 \mathrm{MW}(65 \%, 17 \%$ and $18 \%)$ and the reduction in annual carbon at $20 \mathrm{kt}(49 \%, 18 \%$ and $33 \%)$. 
Table 10.1(a). Baton Rouge metropolitan-wide estimates of cooling and heating annual base energy expenditures and savings [1000\$], and peak power demand and savings [MW] from Heat Island Reduction (HIR) strategies for residential and commercial buildings. Direct savings are from the strategic placement of shade trees and the use of high-albedo roofs on individual buildings, and indirect savings include the impact of reduced air temperature from urban reforestation and high-albedo surfaces.

\begin{tabular}{|c|c|c|c|c|c|c|c|c|c|c|c|c|}
\hline \multirow{2}{*}{$\begin{array}{c}\text { building type } \\
\qquad \& \\
\text { HIR strategy }\end{array}$} & \multicolumn{2}{|c|}{ gas heat } & \multicolumn{2}{|c|}{ electric heat } & \multicolumn{2}{|c|}{$\begin{array}{l}\text { annual electricity }[1000 \$] \\
\text { gas heat }\end{array}$} & \multicolumn{2}{|c|}{$\begin{array}{c}\text { annual gas }[1000 \$] \\
\text { gas heat }\end{array}$} & \multicolumn{4}{|c|}{ peak power $[\mathrm{MW}]$} \\
\hline & -1979 & $1980+$ & -1979 & $1980+$ & -1979 & $1980+$ & -1979 & $1980+$ & -1979 & $1980+$ & -1979 & $1980+$ \\
\hline residence & & & & & & & & & & & & \\
\hline base expenditure \& demand & 64960 & 18942 & 2655 & 3224 & 46980 & 15498 & 17980 & 3444 & 495.9 & 159.9 & 17.1 & 25.3 \\
\hline direct shade tree savings & 2755 & 1230 & 130 & 208 & 4205 & 1476 & -1450 & -246 & 37.7 & 18.0 & 1.3 & 2.9 \\
\hline direct high albedo savings & 4930 & 1230 & 150 & 182 & 5510 & 1312 & -580 & -82 & 39.2 & 9.8 & 1.4 & 1.6 \\
\hline direct combined savings & 7395 & 2460 & 265 & 390 & 9425 & 2788 & -2030 & -328 & 75.4 & 27.1 & 2.6 & 4.3 \\
\hline indirect savings & 1305 & 492 & 40 & 78 & 1740 & 574 & -435 & -82 & 7.2 & 1.6 & 0.2 & 0.3 \\
\hline $\begin{array}{l}\text { direct \& indirect savings } \\
\text { office }\end{array}$ & 8410 & 2788 & 300 & 442 & 11020 & 3198 & -2610 & -410 & 82.6 & 28.7 & 2.8 & 4.5 \\
\hline base expenditure \& demand & 5970 & 3096 & 0 & 518 & 5670 & 3030 & 300 & 66 & 46.9 & 26.8 & 0.0 & 4.5 \\
\hline direct shade tree savings & 174 & 84 & 0 & 14 & 180 & 90 & -6 & -6 & 0.5 & 0.2 & 0.0 & 0.0 \\
\hline direct high albedo savings & 300 & 102 & 0 & 17 & 324 & 108 & -24 & -6 & 1.4 & 0.7 & 0.0 & 0.1 \\
\hline direct combined savings & 462 & 186 & 0 & 31 & 480 & 192 & -18 & -6 & 2.0 & 1.1 & 0.0 & 0.2 \\
\hline indirect savings & 108 & 60 & 0 & 10 & 114 & 66 & -6 & -6 & 1.4 & 0.7 & 0.0 & 0.1 \\
\hline $\begin{array}{l}\text { direct \& indirect savings } \\
\text { retail }\end{array}$ & 570 & 324 & 0 & 55 & 594 & 336 & -24 & -12 & 3.5 & 1.8 & 0.0 & 0.3 \\
\hline base expenditure \& demand & 12649 & 1776 & 976 & 0 & 12519 & 1776 & 130 & 0 & 66.2 & 10.4 & 5.1 & 0.0 \\
\hline direct shade tree savings & 481 & 88 & 37 & 0 & 481 & 88 & 0 & 0 & 1.2 & 0.2 & 0.1 & 0.0 \\
\hline direct high albedo savings & 949 & 108 & 73 & 0 & 962 & 108 & -13 & 0 & 4.4 & 0.7 & 0.3 & 0.0 \\
\hline direct combined savings & 1456 & 180 & 112 & 0 & 1482 & 180 & -26 & 0 & 6.0 & 1.1 & 0.5 & 0.0 \\
\hline indirect savings & 169 & 32 & 13 & 0 & 169 & 32 & 0 & 0 & 1.0 & 0.2 & 0.1 & 0.0 \\
\hline direct $\&$ indirect savings & 1807 & 208 & 139 & 0 & 1833 & 208 & -26 & 0 & 7.0 & 1.3 & 0.5 & 0.0 \\
\hline
\end{tabular}

a Base energy expenditures and peak power demand are calculated for buildings without shade trees and with a dark roof (albedo 0.2). Direct savings are determined for buildings with 8 shade trees (retail 4 ) and a high-albedo roof (residential 0.5 and commercial 0.6 ).

b Combined HIR effects are not precisely the sum of individual effects. 
Table 10.1(b). Baton Rouge metropolitan-wide estimates of annual energy savings, peak power avoided and annual carbon reduction from Heat Island Reduction (HIR) strategies for residential and commercial buildings. Direct savings are from the strategic placement of shade trees and the use of high-albedo roofs on individual buildings, and indirect savings include the impact of reduced air temperature from urban reforestation and high-albedo surfaces.

\begin{tabular}{|c|c|c|c|c|c|c|c|}
\hline $\begin{array}{c}\text { building type } \\
\& \\
\text { HIR } \\
\text { strategy }\end{array}$ & $\begin{array}{c}\text { annual } \\
\text { energy } \\
\text { savings } \\
{[\mathrm{M} \$]}\end{array}$ & \multicolumn{2}{|c|}{$\begin{array}{l}\text { annual } \\
\text { electricity } \\
\text { savings }\end{array}$} & \multicolumn{2}{|c|}{$\begin{array}{c}\text { annual } \\
\text { natural gas } \\
\text { deficit }\end{array}$} & $\begin{array}{c}\text { peak } \\
\text { power } \\
\text { avoided } \\
{[\mathrm{MW}]}\end{array}$ & $\begin{array}{c}\text { annual } \\
\text { carbon } \\
\text { reduction } \\
{[\mathrm{kt}]}\end{array}$ \\
\hline residence & & & & & & & \\
\hline base case & 89.8 & 925.0 & 68.4 & 29.9 & 21.4 & 698.2 & 154.5 \\
\hline direct shade tree & 4.3 & 81.4 & 6.0 & 2.4 & 1.7 & 59.9 & 13.6 \\
\hline direct high albedo & 6.5 & 96.8 & 7.2 & 0.9 & 0.7 & 52.0 & 16.2 \\
\hline direct combined & 10.5 & 174.1 & 12.9 & 3.3 & 2.4 & 109.4 & 29.1 \\
\hline indirect & 1.9 & 32.9 & 2.4 & 0.7 & 0.5 & 9.3 & 5.5 \\
\hline direct \& indirect & 11.9 & 202.4 & 15.0 & 4.2 & 3.0 & 118.6 & 33.8 \\
\hline office & & & & & & & \\
\hline base case & 9.6 & 131.9 & 9.2 & 0.6 & 0.4 & 78.2 & 22.0 \\
\hline direct shade tree & 0.3 & 4.1 & 0.3 & 0.0 & 0.0 & 0.7 & 0.7 \\
\hline direct high albedo & 0.4 & 6.4 & 0.4 & 0.0 & 0.0 & 2.2 & 1.1 \\
\hline direct combined & 0.7 & 10.1 & 0.7 & 0.0 & 0.0 & 3.3 & 1.7 \\
\hline indirect & 0.2 & 2.7 & 0.2 & 0.0 & 0.0 & 2.2 & 0.5 \\
\hline direct \& indirect & 0.9 & 14.1 & 1.0 & 0.1 & 0.0 & 5.6 & 2.4 \\
\hline retail & & & & & & & \\
\hline base case & 15.4 & 218.5 & 15.3 & 0.2 & 0.1 & 81.7 & 36.5 \\
\hline direct shade tree & 0.6 & 8.7 & 0.6 & 0.0 & 0.0 & 1.5 & 1.4 \\
\hline direct high albedo & 1.1 & 16.4 & 1.1 & 0.0 & 0.0 & 5.4 & 2.7 \\
\hline direct combined & 1.7 & 25.4 & 1.8 & 0.0 & 0.0 & 7.6 & 4.2 \\
\hline indirect & 0.2 & 3.1 & 0.2 & 0.0 & 0.0 & 1.3 & 0.5 \\
\hline direct \& indirect & 2.2 & 31.2 & 2.2 & 0.0 & 0.0 & 8.8 & 5.2 \\
\hline total & & & & & & & \\
\hline base case & 114.8 & 1275.3 & 92.8 & 30.7 & 21.9 & 858.1 & 213.0 \\
\hline direct shade tree & 5.2 & 94.2 & 6.9 & 2.4 & 1.7 & 62.1 & 15.7 \\
\hline direct high albedo & 8.0 & 119.6 & 8.7 & 1.0 & 0.7 & 59.6 & 20.0 \\
\hline direct combined & 12.9 & 209.6 & 15.3 & 3.4 & 2.4 & 120.3 & 35.0 \\
\hline indirect & 2.3 & 38.7 & 2.8 & 0.7 & 0.5 & 12.8 & 6.5 \\
\hline direct \& indirect & 15.0 & 247.7 & 18.1 & 4.3 & 3.1 & 133.0 & 41.4 \\
\hline
\end{tabular}

a Metropolitan-wide annual energy savings [M $\$=M i l l i o n \$]$, annual electricity savings $[\mathrm{M} \$ \&$ BWh $=$ BillionWatt-hour], annual natural gas deficit $[\mathrm{M} \$ \& \mathrm{Mth}=$ Million therms], peak power avoided $[\mathrm{MW}=$ MegaWatt $]$ and annual carbon reduction [ $\mathrm{kt}=$ thousand tons].

b Base energy expenditures and peak power demand are calculated for buildings without shade trees and with a dark roof (albedo 0.2). Direct savings are determined for buildings with 8 shade trees (retail 4) and a high-albedo roof (residential 0.5 and commercial 0.6 ).

c Combined HIR effects are not precisely the sum of individual effects.

d The conversion from BWh to carbon is for the US mix of electricity. In 1995, DOE/EIA-0383(97) (EIA 1997) shows that $3000 \mathrm{BkWh}$ sold emitted $500 \mathrm{MtC}$ (million metric tons of carbon), thus $1 \mathrm{BWh}$ emits $0.167 \mathrm{ktC}$. 
Table 10.2(a). Sacramento metropolitan-wide estimates of cooling and heating annual base energy expenditures and savings [1000\$], and peak power demand and savings [MW] from Heat Island Reduction (HIR) strategies for residential and commercial buildings. Direct savings are from the strategic placement of shade trees and the use of high-albedo roofs on individual buildings, and indirect savings include the impact of reduced air temperature from urban reforestation and high-albedo surfaces.

\begin{tabular}{|c|c|c|c|c|c|c|c|c|c|c|c|c|}
\hline \multirow{3}{*}{$\begin{array}{l}\text { building type } \\
\qquad \& \\
\text { HIR strategy } \\
\end{array}$} & \multicolumn{4}{|c|}{ annual total energy $[1000 \$]$} & \multirow{2}{*}{\multicolumn{2}{|c|}{$\begin{array}{l}\text { annual electricity }[1000 \$] \\
\text { gas heat }\end{array}$}} & \multirow{2}{*}{\multicolumn{2}{|c|}{$\begin{array}{c}\text { annual gas }[1000 \$] \\
\text { gas heat }\end{array}$}} & \multicolumn{4}{|c|}{ peak power [MW] } \\
\hline & \multicolumn{2}{|c|}{ gas heat } & \multicolumn{2}{|c|}{ electric heat } & & & & & \multicolumn{2}{|c|}{ gas heat } & \multicolumn{2}{|c|}{ electric heat } \\
\hline & -1979 & $1980+$ & -1979 & $1980+$ & -1979 & $1980+$ & -1979 & $1980+$ & -1979 & $1980+$ & -1979 & $1980+$ \\
\hline residence & & & & & & & & & & & & \\
\hline base expenditure \& demand & 152308 & 31790 & 30268 & 8626 & 62582 & 14025 & 89726 & 17765 & 1349.7 & 368.4 & 164.7 & 74.9 \\
\hline direct shade tree savings & 3016 & 1122 & 322 & 190 & 12064 & 2805 & -9048 & -1683 & 101.8 & 33.7 & 12.4 & 6.8 \\
\hline direct high albedo savings & 7163 & 1496 & 368 & 190 & 10179 & 2057 & -3016 & -561 & 94.2 & 22.4 & 11.5 & 4.6 \\
\hline direct combined savings & 9048 & 2805 & 690 & 342 & 21489 & 5236 & -12441 & -2431 & 214.9 & 59.8 & 26.2 & 12.2 \\
\hline indirect savings & 2639 & 748 & 184 & 114 & 5655 & 1309 & -3016 & -561 & 60.3 & 16.8 & 7.4 & 3.4 \\
\hline $\begin{array}{l}\text { direct \& indirect savings } \\
\text { office }\end{array}$ & 9048 & 2992 & 874 & 456 & 25636 & 6171 & -16588 & -3179 & 279.0 & 80.4 & 34.0 & 16.3 \\
\hline base expenditure $\&$ demand & 17532 & 6160 & 2018 & 1335 & 15732 & 5880 & 1800 & 280 & 141.1 & 59.1 & 15.7 & 12.7 \\
\hline direct shade tree savings & 1278 & 434 & 142 & 93 & 1296 & 434 & -18 & 0 & 7.4 & 2.2 & 0.8 & 0.5 \\
\hline direct high albedo savings & 1044 & 238 & 114 & 51 & 1134 & 252 & -90 & -14 & 7.4 & 2.0 & 0.8 & 0.4 \\
\hline direct combined savings & 2322 & 658 & 256 & 141 & 2412 & 686 & -90 & -28 & 14.9 & 4.5 & 1.7 & 1.0 \\
\hline indirect savings & 612 & 266 & 70 & 57 & 630 & 266 & -18 & 0 & 6.3 & 2.4 & 0.7 & 0.5 \\
\hline $\begin{array}{l}\text { direct } \& \text { indirect savings } \\
\text { retail }\end{array}$ & 2880 & 924 & 320 & 192 & 2988 & 952 & -108 & -28 & 20.9 & 6.7 & 2.3 & 1.4 \\
\hline base expenditure \& demand & 40404 & 3248 & 2086 & 406 & 39702 & 3248 & 702 & 0 & 228.9 & 23.7 & 11.7 & 3.0 \\
\hline direct shade tree savings & 2769 & 280 & 142 & 35 & 2769 & 280 & 0 & 0 & 11.7 & 1.7 & 0.6 & 0.2 \\
\hline direct high albedo savings & 3471 & 216 & 178 & 26 & 3549 & 216 & -78 & 0 & 16.8 & 1.4 & 0.9 & 0.2 \\
\hline direct combined savings & 6396 & 496 & 328 & 62 & 6474 & 496 & -78 & 0 & 30.0 & 3.8 & 1.5 & 0.5 \\
\hline indirect savings & 1014 & 128 & 52 & 16 & 1014 & 128 & 0 & 0 & 7.0 & 0.7 & 0.4 & 0.1 \\
\hline direct \& indirect savings & 7332 & 608 & 376 & 76 & 7410 & 608 & .78 & 0 & 37.4 & 4.6 & 1.9 & 0.6 \\
\hline
\end{tabular}

a Base energy expenditures and peak power demand are calculated for buildings without shade trees and with a dark roof (albedo 0.2). Direct savings are determined for buildings with 8 shade trees (retail 4) and a high-albedo roof (residential 0.5 and commercial 0.6 ).

b Combined HIR effects are not precisely the sum of individual effects. 
Table 10.2(b). Sacramento metropolitan-wide estimates of annual energy savings, peak power avoided and annual carbon reduction from Heat Island Reduction (HIR) strategies for residential and commercial buildings. Direct savings are from the strategic placement of shade trees and the use of high-albedo roofs on individual buildings, and indirect savings include the impact of reduced air temperature from urban reforestation and high-albedo surfaces.

\begin{tabular}{|c|c|c|c|c|c|c|c|}
\hline $\begin{array}{c}\text { building type } \\
\text { \& } \\
\text { HIR } \\
\text { strategy }\end{array}$ & $\begin{array}{c}\text { annual } \\
\text { energy } \\
\text { savings } \\
{[\mathrm{M} \$]}\end{array}$ & $\begin{array}{r}\text { ar } \\
\text { elec } \\
\text { sa } \\
{[\mathrm{BWh}]}\end{array}$ & $\begin{array}{l}\text { ty } \\
\text { s } \\
{[M \$ 1]}\end{array}$ & $\begin{array}{r}\text { an } \\
\text { natu } \\
\text { de } \\
{[\text { Mth] }}\end{array}$ & $\begin{array}{l}\text { gas } \\
\text { it } \\
{[\mathrm{M} \$]}\end{array}$ & $\begin{array}{c}\text { peak } \\
\text { power } \\
\text { avoided } \\
\text { [MW] }\end{array}$ & $\begin{array}{c}\text { annual } \\
\text { carbon } \\
\text { reduction } \\
{[\mathrm{kt}]}\end{array}$ \\
\hline residence & & & & & & & \\
\hline base case & 223.0 & 1383.2 & 115.5 & 157.8 & 107.5 & 1957.7 & 231.0 \\
\hline direct shade tree & 4.7 & 184.2 & 15.4 & 15.8 & 10.7 & 154.7 & 30.8 \\
\hline direct high albedo & 9.2 & 153.2 & 12.8 & 5.3 & 3.6 & 132.7 & 25.6 \\
\hline direct combined & 12.9 & 332.4 & 27.8 & 21.8 & 14.9 & 313.1 & 55.5 \\
\hline indirect & 3.7 & 87.0 & 7.3 & 5.3 & 3.6 & 87.9 & 14.5 \\
\hline direct \& indirect & 13.4 & 396.9 & 33.1 & 29.0 & 19.8 & 409.7 & 66.3 \\
\hline office & & & & & & & \\
\hline base case & 27.0 & 303.0 & 25.0 & 3.2 & 2.1 & 228.6 & 50.6 \\
\hline direct shade tree & 1.9 & 23.8 & 2.0 & 0.0 & 0.0 & 10.9 & 4.0 \\
\hline direct high albedo & 1.4 & 18.8 & 1.6 & 0.2 & 0.1 & 10.6 & 3.1 \\
\hline direct combined & 3.4 & 42.4 & 3.5 & 0.2 & 0.1 & 22.1 & 7.1 \\
\hline indirect & 1.0 & 12.4 & 1.0 & 0.0 & 0.0 & 9.9 & 2.1 \\
\hline direct $\&$ indirect & 4.3 & 54.0 & 4.5 & 0.2 & 0.1 & 31.3 & 9.0 \\
\hline retail & & & & & & & \\
\hline base case & 46.1 & 551.5 & 45.4 & 1.1 & 0.7 & 267.3 & 92.1 \\
\hline direct shade tree & 3.2 & 39.2 & 3.2 & 0.0 & 0.0 & 14.2 & 6.5 \\
\hline direct high albedo & 3.9 & 48.2 & 4.0 & 0.1 & 0.1 & 19.3 & 8.0 \\
\hline direct combined & 7.3 & 89.3 & 7.4 & 0.1 & 0.1 & 35.8 & 14.9 \\
\hline indirect & 1.2 & 14.7 & 1.2 & 0.0 & 0.0 & 8.2 & 2.5 \\
\hline direct \& indirect & 8.4 & 102.8 & 8.5 & 0.1 & 0.1 & 44.5 & 17.2 \\
\hline total & & & & & & & \\
\hline base case & 296.2 & 2237.7 & 185.9 & 162.2 & 110.3 & 2453.6 & 373.7 \\
\hline direct shade tree & 9.8 & 247.2 & 20.6 & 15.8 & 10.7 & 179.8 & 41.3 \\
\hline direct high albedo & 14.6 & 220.2 & 18.3 & 5.5 & 3.8 & 162.6 & 36.8 \\
\hline direct combined & 23.5 & 464.2 & 38.6 & 22.1 & 15.1 & 371.0 & 77.5 \\
\hline indirect & 5.9 & 114.1 & 9.5 & 5.3 & 3.6 & 106.0 & 19.0 \\
\hline direct \& indirect & 26.1 & 553.7 & 46.1 & 29.4 & 20.0 & 485.5 & 92.5 \\
\hline
\end{tabular}

a Metropolitan-wide annual energy savings [M $\$=$ Million $\$$, annual electricity savings [M $\$$ \& $B \mathrm{~h}=$ BillionWatt-hour], annual natural gas deficit $[\mathrm{M} \$ \& \mathrm{Mth}=$ Million therms], peak power avoided [MW $=$ MegaWatt] and annual carbon reduction $[\mathrm{kt}=$ thousand tons].

b Base energy expenditures and peak power demand are calculated for buildings without shade trees and with a dark roof (albedo 0.2). Direct savings are determined for buildings with 8 shade trees (retail 4) and a high-albedo roof (residential 0.5 and commercial 0.6 ).

c Combined HIR effects are not precisely the sum of individual effects.

d The conversion from BWh to carbon is for the US mix of electricity. In 1995, DOE/EIA-0383(97) (EIA 1997) shows that $3000 \mathrm{BkWh}$ sold emitted $500 \mathrm{MtC}$ (million metric tons of carbon), thus $1 \mathrm{BWh}$ emits $0.167 \mathrm{ktC}$. 
Table 10.3(a). Salt Lake City metropolitan-wide estimates of cooling and heating annual base energy expenditures and savings [1000\$], and peak power demand and savings [MW] from Heat Island Reduction (HIR) strategies for residential and commercial buildings. Direct savings are from the strategic placement of shade trees and the use of high-albedo roofs on individual buildings, and indirect savings include the impact of reduced air temperature from urban reforestation and high-albedo surfaces.

\begin{tabular}{|c|c|c|c|c|c|c|c|c|c|c|c|c|}
\hline \multirow{3}{*}{$\begin{array}{c}\text { building type } \\
\qquad \& \\
\text { HIR strategy }\end{array}$} & \multicolumn{4}{|c|}{ annual total energy [1000\$] } & \multirow{2}{*}{\multicolumn{2}{|c|}{$\begin{array}{c}\text { annual electricity [1000\$] } \\
\text { gas heat }\end{array}$}} & \multirow{2}{*}{\multicolumn{2}{|c|}{$\begin{array}{c}\text { annual gas }[1000 \$] \\
\text { gas heat }\end{array}$}} & \multicolumn{4}{|c|}{ peak power $[\mathrm{MW}]$} \\
\hline & \multicolumn{2}{|c|}{ gas heat } & \multicolumn{2}{|c|}{ electric heat } & & & & & \multicolumn{2}{|c|}{ gas heat } & \multicolumn{2}{|c|}{ electric heat } \\
\hline & -1979 & $1980+$ & -1979 & $1980+$ & -1979 & $1980+$ & -1979 & $1980+$ & -1979 & $1980+$ & -1979 & $1980+$ \\
\hline residence & & & & & & & & & & & & \\
\hline base expenditure \& demand & 27450 & 19980 & 0 & 446 & 7920 & 6216 & 19530 & 13764 & 157.9 & 139.9 & 0.0 & 1.9 \\
\hline direct shade tree savings & -315 & 74 & 0 & 11 & 945 & 962 & -1260 & -888 & 10.3 & 11.1 & 0.0 & 0.1 \\
\hline direct high albedo savings & 405 & 148 & 0 & -2 & 855 & 592 & -450 & -444 & 12.6 & 8.9 & 0.0 & 0.1 \\
\hline direct combined savings & 90 & 222 & 0 & 8 & 1755 & 1406 & -1665 & -1184 & 22.9 & 19.2 & 0.0 & 0.3 \\
\hline indirect savings & 45 & 148 & 0 & 3 & 540 & 444 & .495 & .296 & 6.8 & 5.9 & 0.0 & 0.1 \\
\hline direct $\&$ indirect savings & 135 & 296 & 0 & 11 & 2205 & 1776 & -2070 & -1480 & 29.7 & 25.2 & 0.0 & 0.3 \\
\hline office & & & & & & & & & & & & \\
\hline base expenditure \& demand & 5742 & 1848 & 0 & 0 & 4446 & 1524 & 1296 & 324 & 65.9 & 24.1 & 0.0 & 0.0 \\
\hline direct shade tree savings & 414 & 144 & 0 & 0 & 423 & 150 & -9 & .6 & 4.7 & 2.1 & 0.0 & 0.0 \\
\hline direct high albedo savings & 261 & 48 & 0 & 0 & 306 & 66 & -45 & -18 & 3.1 & 0.8 & 0.0 & 0.0 \\
\hline direct combined savings & 666 & 186 & 0 & 0 & 720 & 210 & -54 & -24 & 7.5 & 2.9 & 0.0 & 0.0 \\
\hline indirect savings & 180 & 66 & 0 & 0 & 198 & 72 & -18 & -6 & 3.2 & 1.1 & 0.0 & 0.0 \\
\hline direct \& indirect savings & 846 & 246 & 0 & 0 & 909 & 276 & -63 & -30 & 10.7 & 4.0 & 0.0 & 0.0 \\
\hline retail & & & & & & & & & & & & \\
\hline base expenditure \& demand & 10800 & 723 & 0 & 0 & 10134 & 717 & 666 & 6 & 90.7 & 7.5 & 0.0 & 0.0 \\
\hline direct shade tree savings & 702 & 63 & 0 & 0 & 702 & 63 & 0 & 0 & 4.1 & 0.5 & 0.0 & 0.0 \\
\hline direct high albedo savings & 864 & 39 & 0 & 0 & 918 & 42 & -54 & -3 & 6.1 & 0.4 & 0.0 & 0.0 \\
\hline direct combined savings & 1638 & 105 & 0 & 0 & 1692 & 108 & -54 & -3 & 11.5 & 0.9 & 0.0 & 0.0 \\
\hline indirect savings & 306 & 27 & 0 & 0 & 306 & 27 & 0 & 0 & 2.5 & 0.2 & 0.0 & 0.0 \\
\hline direct $\&$ indirect savings & 1926 & 129 & 0 & 0 & 1980 & 135 & -54 & -6 & 13.9 & 1.1 & 0.0 & 0.0 \\
\hline
\end{tabular}

a Base energy expenditures and peak power demand are calculated for buildings without shade trees and with a dark roof (albedo 0.2). Direct savings are determined for buildings with 8 shade trees (retail 4) and a high-albedo roof (residential 0.5 and commercial 0.6 ).

b Combined HIR effects are not precisely the sum of individual effects. 
Table 10.3(b). Salt Lake City metropolitan-wide estimates of annual energy savings, peak power avoided and annual carbon reduction from Heat Island Reduction (HIR) strategies for residential and commercial buildings. Direct savings are from the strategic placement of shade trees and the use of high-albedo roofs on individual buildings, and indirect savings include the impact of reduced air temperature from urban reforestation and high-albedo surfaces.

\begin{tabular}{|c|c|c|c|c|c|c|c|}
\hline $\begin{array}{c}\text { building type } \\
\& \\
\text { HIR } \\
\text { strategy }\end{array}$ & $\begin{array}{c}\text { annual } \\
\text { energy } \\
\text { savings } \\
\text { [M\$] }\end{array}$ & \multicolumn{2}{|c|}{$\begin{array}{l}\text { annual } \\
\text { electricity } \\
\text { savings }\end{array}$} & \multicolumn{2}{|c|}{$\begin{array}{c}\text { annual } \\
\text { natural gas } \\
\text { deficit }\end{array}$} & $\begin{array}{c}\text { peak } \\
\text { power } \\
\text { avoided } \\
\text { [MW] }\end{array}$ & $\begin{array}{c}\text { annual } \\
\text { carbon } \\
\text { reduction } \\
{[\mathrm{kt}]}\end{array}$ \\
\hline residence & & & & & & & \\
\hline base case & 47.9 & 210.4 & 14.6 & 64.9 & 33.3 & 299.7 & 35.1 \\
\hline direct shade tree & -0.2 & 27.7 & 1.9 & 4.2 & 2.1 & 21.5 & 4.6 \\
\hline direct high albedo & 0.6 & 20.9 & 1.4 & 1.7 & 0.9 & 21.6 & 3.5 \\
\hline direct combined & 0.3 & 45.7 & 3.2 & 5.6 & 2.8 & 42.4 & 7.6 \\
\hline indirect & 0.2 & 14.2 & 1.0 & 1.5 & 0.8 & 12.8 & 2.4 \\
\hline direct \& indirect & 0.4 & 57.6 & 4.0 & 6.9 & 3.5 & 55.2 & 9.6 \\
\hline office & & & & & & & \\
\hline base case & 7.6 & 106.6 & 6.0 & 4.1 & 1.6 & 90.0 & 17.8 \\
\hline direct shade tree & 0.6 & 10.2 & 0.6 & 0.0 & 0.0 & 6.8 & 1.7 \\
\hline direct high albedo & 0.3 & 6.6 & 0.4 & 0.2 & 0.1 & 3.9 & 1.1 \\
\hline direct combined & 0.9 & 16.6 & 0.9 & 0.2 & 0.1 & 10.4 & 2.8 \\
\hline indirect & 0.2 & 4.8 & 0.3 & 0.1 & 0.0 & 4.3 & 0.8 \\
\hline direct \& indirect & 1.1 & 21.2 & 1.2 & 0.2 & 0.1 & 14.7 & 3.5 \\
\hline retail & & & & & & & \\
\hline base case & 11.5 & 193.8 & 10.9 & 1.7 & 0.7 & 98.2 & 32.4 \\
\hline direct shade tree & 0.8 & 13.7 & 0.8 & 0.0 & 0.0 & 4.6 & 2.3 \\
\hline direct high albedo & 0.9 & 17.1 & 1.0 & 0.1 & 0.1 & 6.5 & 2.9 \\
\hline direct combined & 1.7 & 32.1 & 1.8 & 0.1 & 0.1 & 12.4 & 5.4 \\
\hline indirect & 0.3 & 5.9 & 0.3 & 0.0 & 0.0 & 2.7 & 1.0 \\
\hline direct $\&$ indirect & 2.1 & 37.8 & 2.1 & 0.2 & 0.1 & 15.0 & 6.3 \\
\hline total & & & & & & & \\
\hline base case & 67.0 & 510.8 & 31.4 & 70.8 & 35.6 & 487.9 & 85.3 \\
\hline direct shade tree & 1.1 & 51.6 & 3.3 & 4.2 & 2.2 & 32.9 & 8.6 \\
\hline direct high albedo & 1.8 & 44.6 & 2.8 & 2.0 & 1.0 & 32.0 & 7.5 \\
\hline direct combined & 2.9 & 94.5 & 5.9 & 5.9 & 3.0 & 65.2 & 15.8 \\
\hline indirect & 0.8 & 25.0 & 1.6 & 1.6 & 0.8 & 19.8 & 4.2 \\
\hline direct $\&$ indirect & 3.6 & 116.5 & 7.3 & 7.3 & 3.7 & 84.9 & 19.5 \\
\hline
\end{tabular}

Metropolitan-wide annual energy savings $[\mathrm{M} \$=\mathrm{Million} \$]$, annual electricity savings $[\mathrm{M} \$$ \& $\mathrm{BWh}=$ BillionWatt-hour], annual natural gas deficit $[\mathrm{M} \$$ \& $\mathrm{Mth}=$ Million therms], peak power avoided $[\mathrm{MW}=\mathrm{MegaWatt}]$ and annual carbon reduction $[\mathrm{kt}=$ thousand tons $]$.

b Base energy expenditures and peak power demand are calculated for buildings without shade trees and with a dark roof (albedo 0.2). Direct savings are determined for buildings with 8 shade trees (retail 4) and a high-albedo roof (residential 0.5 and commercial 0.6).

c Combined HIR effects are not precisely the sum of individual effects.

d The conversion from BWh to carbon is for the US mix of electricity. In 1995, DOE/EIA-0383(97) (EIA 1997) shows that $3000 \mathrm{BkWh}$ sold emitted $500 \mathrm{MtC}$ (million metric tons of carbon), thus $1 \mathrm{BWh}$ emits $0.167 \mathrm{ktC}$. 


\section{Conclusions}

In this study, we have investigated the potential of Heat Island Reduction (HIR) strategies (i.e., shade trees, reflective roofs, reflective pavements and urban vegetation) to reduce cooling energy use in buildings in three cities: Baton Rouge, LA, Sacramento, CA and Salt Lake City, UT. The impact of both direct effect (reducing heat gain through the building shell) and indirect effect (reducing the ambient air temperature) was addressed.

To perform this analysis, we identified three building types that offer most savings potential: single-family residence, office and retail store. Each building type was characterized in detail by old or new construction and with a gas furnace or an electric heat pump. We defined prototypical building characteristics for each building type and simulated the impact of HIR strategies on building cooling and heating energy use and peak power demand using the DOE-2.1E model. Our simulations included the impact of (1) strategically-placed shade trees near buildings [direct effect], (2) use of high-albedo roofing material on building [direct effect], (3) combined strategies 1 and 2 [direct effect], (4) cooling of the ambient air by planting urban vegetation and implementation of high-albedo surfaces (pavements and roofs surfaces) [indirect effect] and (5) combined strategies 1,2 and 4 [direct and indirect effects]. We then estimated the total roof area of air-conditioned buildings in each city using readily obtainable data to calculate the metropolitan-wide impact of HIR strategies.

The results show, that in Baton Rouge, potential annual energy savings of $\$ 15 \mathrm{M}$ could be realized by rate-payers from the combined direct and indirect effects of HIR strategies. Additionally, peak power avoidance is estimated at $133 \mathrm{MW}$ and the reduction in annual carbon emissions at $41 \mathrm{kt}$. In Sacramento, the potential annual energy savings is estimated at $\$ 26 \mathrm{M}$, with an avoidance of $486 \mathrm{MW}$ in peak power and a reduction in annual carbon of $92 \mathrm{kt}$. In Salt Lake City; the potential annual energy savings is estimated at $\$ 4 \mathrm{M}$, with an avoidance of $85 \mathrm{MW}$ in peak power and a reduction in annual carbon of $20 \mathrm{kt}$.

Savings from the indirect impact (cooler ambient air temperature) of HIR strategies were $15 \%, 23 \%$ and $22 \%$ of the overall savings for Baton Rouge, Sacramento and Salt Lake City. Our climate simulations indicated a reduction in maximum air temperature of $2^{\circ} \mathrm{F}, 3^{\circ} \mathrm{F}$ and $3^{\circ} \mathrm{F}$, for these cities (Taha 1999b). The indirect savings are a function of local climate and the degree of surface modification possible. For instance, the cooling seasons for Sacramento and Salt Lake City are fairly short, and the potential for ambient cooling by urban vegetation in Baton Rouge is limited because of it's humid climate. Based on this analysis, we anticipate that for most other major US cities, the indirect impact would be in the same range of $15 \%$ to $25 \%$. However, for a very hot and dry climate such as Phoenix (with a long cooling season which can also benefit from all HIR strategies) the indirect potential of a full-scale implementation of HIR strategies may even be larger.

Since, roofs and shade trees offer the direct saving potential, from an energy-saving point of view, programs that focus on reflective roofs and shade trees should have highest priority. However, when considering smog and air-quality issues, programs that focus on reflective surfaces (roofs and pavements) that can cool the ambient air in both humid and dry climate conditions should have priority.

In the next phase of this project, we will perform a similar analysis for two additional UHIPP cities: Chicago and Houston. Using results from the five UHIPP cities and additional analysis for several other cities we will develop a database to extrapolate savings across the US. 


\section{References}

Akbari, H., S. Bretz, D. Kurn and J. Hanford. 1997a. "Peak Power and Cooling Energy Savings of High-Albedo Roofs". Energy and Buildings 25:117-126.

Akbari, H., J. Eto, S. Konopacki, A. Afzal, K. Heinemeier and L. Rainer. 1993. "Integrated Estimation of Commercial Sector End-Use Load Shapes and Energy Use Intensities in the PG\&E Service Area". Lawrence Berkeley National Laboratory Report LBNL-34263. Berkeley, CA.

Akbari, H., S. Konopacki, C. Eley, B. Wilcox, M. Van Geem and D. Parker. 1998. "Calculations for Reflective Roofs in Support of Standard 90.1". ASHRAE Transactions 104(1):984-995.

Akbari, H., D. Kurn, S. Bretz and J. Hanford. 1997b. "Peak Power and Cooling Energy Savings of Shade Trees". Energy and Buildings 25:139-148.

Akridge, J. 1998. "High-Albedo Roof Coatings - Impact on Energy Consumption" ASHRAE Technical Data Bulletin 14(2).

AHS. 1997, 1997 \& 1994. "American Housing Survey for the (New Orleans, Sacramento \& Salt Lake City) Metropolitan Area in (1995, 1996 \& 1992)". US Department of Commerce: Economics and Statistics Administration \& Bureau of the Census. US Department of Housing and Urban Development: Office of Policy Development and Research. (H170/95-30, H170/9658 \& H170/92-15). Washington, DC.

Boutwell, C. and Y. Salinas. 1986. "Building for the Future - Phase I: An Energy Saving Materials Research Project" Oxford: Mississippi Power Co., Rohm and Haas Co. and the University of Mississippi.

Bretz, S. and H. Akbari. 1997. "Long-Term Performance of High-Albedo Roof Coatings". Energy and Buildings 25:159-167.

Building Energy Simulation Group (BESG). 1990. "Overview of the DOE-2 Building Energy Analysis Program, Version 2.1D". Lawrence Berkeley National Laboratory Report LBL-19735, Rev. 1. Berkeley, CA.

California Energy Commission (CEC). 1994. "Technology Energy Savings Volume II: Building Prototypes". California Energy Commission Report P300-94-007. Sacramento, CA.

Commercial Buildings Energy Consumption Survey (CBECS). 1995. Commercial Buildings Characteristics 1995. Energy Information Administration. Washington, DC.

Cool Roofing Materials Database (CRMD).1998. http://eetd.lbl.gov/coolroof. Lawrence Berkeley National Laboratory. Berkeley, CA.

Energy Information Administration (EIA). 1998. http://www.eia.doe.gov. Washington, DC.

Energy Information Administration (EIA). 1997. DOE/EIA-0383(97) Annual Energy Outlook 1997. Tables A8 and A19. Washington, DC.

Gartland, L., S. Konopacki and H. Akbari. 1996. "Modeling the Effects of Reflective Roofing". ACEEE Summer Study on Energy Efficiency in Buildings 4:117-124. Pacific Grove, CA. 


\section{References (continued)}

Henderson, H. 1998. "Part Load Curves for Use in DOE-2". Draft report prepared for Lawrence

Berkeley National Laboratory and Florida Solar Energy Center. CDH Energy Corp., Cazenovia, NY. January 16, 1998.

Hildebrandt, E., W. Bos and R. Moore. 1998. "Assessing the Impacts of White Roofs on Building Energy Loads" ASHRAE Technical Data Bulletin 14(2).

Konopacki, S. and H. Akbari. 1998a. "Simulated Impact of Roof Surface Solar Absorptance, Attic, and Duct Insulation on Cooling and Heating Energy Use in Single-Family New Residential Buildings". Lawrence Berkeley National Laboratory Report LBNL-41834. Berkeley, CA.

Konopacki, S. and H. Akbari. 1998b. "Demonstration of Energy Savings of Cool Roofs: Phase II". Lawrence Berkeley National Laboratory - Heat Island Group Technical Note. Berkeley, CA.

Konopacki, S., H. Akbari, L. Gartland and L. Rainer. 1998c. "Demonstration of Energy Savings of Cool Roofs". Lawrence Berkeley National Laboratory Report LBNL-40673. Berkeley, CA.

Konopacki, S., H. Akbari, M. Pomerantz, S. Gabersek and L. Gartland. 1997. "Cooling Energy Savings Potential of Light-Colored Roofs for Residential and Commercial Buildings in 11 US Metropolitan Areas". Lawrence Berkeley National Laboratory Report LBNL-39433. Berkeley, CA.

National Appliance Energy Conservation Act of 1987 (NAECA). 1987.

National Renewable Energy Laboratory (NREL). 1995. "User's Manual for TMY2s".

Parker, D., J. Huang, S. Konopacki, L. Gartland, J. Sherwin and L. Gu. 1998. "Measured and Simulated Performance of Reflective Roofing Systems in Residential Buildings". ASHRAE Transactions 104(1):963-975.

Parker, D., J. Sonne and J. Sherwin. 1997. "Demonstration of Cooling Savings of Light Colored Roof Surfacing in Florida Commercial Buildings: Retail Strip Mall". Florida Solar Energy Center Report FSEC-CR-964-97. Cocoa, Fl.

Residential Energy Consumption Survey (RECS). 1992. Housing Characteristics 1990. Energy Information Administration. Washington, DC.

Sherman, M., D. Wilson and D. Kiel. 1986. "Variability in Residential Air Leakage". Measured Air Leakage in Buildings ASTM STP-904. Philadelphia, PA.

Taha, H. and S.C. Chang. 1999a. "Modeling the Potential Meteorological and Ozone Air Quality Impacts of the US EPA's Urban Heat Island Pilot Project (UHIPP) in Five US Regions". Lawrence Berkeley National Laboratory Draft Report LBNL-44222. Berkeley, CA.

Taha, H. 1999b. "Constructing Full-Year Modified Weather Based on Episodic Meteorological Simulation Results". Lawrence Berkeley National Laboratory Draft Report LBNL-44107. Berkeley, CA.

Taha, H., S. Konopacki and S. Gabersek. 1996. "Modeling the Meteorological and Energy Effects of Urban Heat Islands and Their Mitigation: a 10 Region Study". Lawrence Berkeley National Laboratory Draft Report LBNL-39335. Berkeley, CA.

US Census. (1990). http://venus.census.gov/cdrom/lookup/. 


\section{Appendix A. Simulated Energy Use \& Savings and Peak Power Demand \& Savings}

Cooling and heating energy use were simulated with the DOE-2.1E building energy simulation program using local TMY2 weather data for residential, office and retail store prototypical buildings. The buildings were characterized for old (those built prior to 1980) or new (built 1980 or later) construction, with a gas furnace or an electric heat pump, several building orientations $(\phi)$ (residence: $\phi=0,90,180 \& 270$ office: $\phi=0 \& 90$ retail: $\phi=0,90 \& 270$ ), multiple ceiling insulation levels (old construction: R-7, 11 \& 19 new construction: R-19, 30 \& 38), low and high levels of roof albedo (residence: $0.2 \& 0.5$ office and retail $0.2 \& 0.6$ ), and number of shade trees (residence and office: $0 \& 8$ retail: $0 \& 4$ ). This appendix contains the simulation results for all the prototypical variations. The tables are arranged in the following format.
A.1. Baton Rouge
A.2. Sacramento
A.3. Salt Lake City
a. residence
b. office
c. retail
(i) annual total energy expenditures [ $\left.\$ / 1000 \mathrm{ft}^{2}\right]$ and savings [\%]
(ii) annual electricity expenditures $\left[\$ / 1000 \mathrm{ft}^{2}\right]$ and savings [\%]
(iii) annual natural gas expenditures $\left[\$ / 1000 \mathrm{ft}^{2}\right]$ and savings [\%]
(iv) peak power demand $\left[\mathrm{kW} / 1000 \mathrm{ft}^{2}\right]$ and savings [\%] 
Table A.1.a(i). Baton Rouge simulated cooling and heating annual total energy expenditures $\left[\$ / 1000 \mathrm{ft}^{2}\right]$, the direct savings [\%] from the strategic placement of shade trees and the use of high-albedo roofs, and the indirect savings [\%] from heat island reduction strategies for residential buildings. Base energy expenditure is calculated for buildings without shade trees and with a dark roof (albedo 0.2 ). Direct savings are determined for buildings with 8 shade trees and a high-albedo roof (albedo 0.5). To estimate direct savings for other changes in albedo $(\Delta \mathrm{a})$ multiply the savings by the ratio $\Delta \mathrm{a} / 0.3$.

\begin{tabular}{|c|c|c|c|c|c|c|c|c|c|c|c|c|}
\hline \multirow{3}{*}{$\begin{array}{c}\text { building azimuth } \\
\& \\
\text { HIR strategy }\end{array}$} & \multicolumn{6}{|c|}{ gas heat } & \multicolumn{6}{|c|}{ electric heat } \\
\hline & \multicolumn{3}{|c|}{-1979} & \multicolumn{3}{|c|}{$1980+$} & \multicolumn{3}{|c|}{-1979} & \multicolumn{3}{|c|}{$1980+$} \\
\hline & $\mathrm{R}-7$ & $\mathrm{R}-11$ & $\mathrm{R}-19$ & $\mathrm{R}-19$ & $\mathrm{R} \cdot 30$ & $\mathrm{R}-38$ & $\mathrm{R}-7$ & $\mathrm{R}-11$ & $\mathrm{R}-19$ & $\mathrm{R}-19$ & $\mathrm{R}-30$ & $\mathrm{R}-38$ \\
\hline \multicolumn{13}{|l|}{$\phi=0$} \\
\hline base expenditure & 464 & 440 & 416 & 236 & 226 & 222 & 541 & 517 & 493 & 252 & 242 & 237 \\
\hline direct shade tree savings & 3 & 4 & 4 & 6 & 6 & 6 & 4 & 4 & 4 & 6 & 6 & 6 \\
\hline direct high albedo savings & 8 & 8 & 7 & 8 & 7 & 7 & 6 & 6 & 5 & 7 & 6 & 6 \\
\hline direct combined savings & 11 & 11 & 11 & 14 & 13 & 12 & 10 & 10 & 9 & 13 & 12 & 12 \\
\hline indirect savings & 2 & 2 & 2 & 3 & 3 & 3 & 2 & 2 & 2 & 2 & 2 & 2 \\
\hline direct $\&$ indirect savings & 13 & 13 & 12 & 15 & 15 & 14 & 11 & 11 & 11 & 14 & 14 & 13 \\
\hline \multicolumn{13}{|l|}{$\phi=90$} \\
\hline base expenditure & 475 & 450 & 426 & 244 & 235 & 231 & 565 & 539 & 513 & 264 & 253 & 249 \\
\hline direct shade tree savings & 4 & 5 & 5 & 7 & 8 & 8 & 6 & 6 & 5 & 8 & 8 & 8 \\
\hline direct high albedo savings & 8 & 7 & 6 & 7 & 6 & 6 & 6 & 5 & 5 & 6 & 6 & 5 \\
\hline direct combined savings & 12 & 12 & 11 & 14 & 14 & 13 & 11 & 11 & 10 & 13 & 13 & 13 \\
\hline indirect savings & 2 & 2 & 2 & 2 & 3 & 3 & 2 & 1 & 2 & 2 & 2 & 2 \\
\hline direct \& indirect savings & 13 & 13 & 13 & 16 & 15 & 15 & 13 & 12 & 12 & 15 & 15 & 14 \\
\hline \multicolumn{13}{|l|}{$\phi=180$} \\
\hline base expenditure & 471 & 446 & 422 & 237 & 227 & 222 & 552 & 527 & 503 & 254 & 244 & 239 \\
\hline direct shade tree savings & 3 & 3 & 3 & 5 & 4 & 4 & 4 & 4 & 4 & 4 & 5 & 5 \\
\hline direct high albedo savings & 8 & 7 & 7 & 7 & 7 & 6 & 6 & 6 & 5 & 6 & 6 & 5 \\
\hline direct combined savings & 11 & 10 & 10 & 11 & 11 & 10 & 9 & 9 & 9 & 11 & 10 & 10 \\
\hline indirect savings & 2 & 2 & 2 & 3 & 2 & 2 & 2 & 2 & 1 & 2 & 2 & 2 \\
\hline direct \& indirect savings & 12 & 12 & 12 & 13 & 13 & 12 & 11 & 10 & 10 & 12 & 12 & 12 \\
\hline \multicolumn{13}{|l|}{$\phi=\mathbf{2 7 0}$} \\
\hline base expenditure & 480 & 455 & 432 & 246 & 237 & 232 & 564 & 539 & 515 & 264 & 254 & 250 \\
\hline direct shade tree savings & 5 & 5 & 5 & 7 & 8 & 7 & 6 & 6 & 6 & 8 & 8 & 8 \\
\hline direct high albedo savings & 8 & 7 & 6 & 7 & 6 & 6 & 6 & 5 & 5 & 6 & 6 & 6 \\
\hline direct combined savings & 12 & 12 & 12 & 14 & 14 & 13 & 11 & 11 & 10 & 13 & 13 & 13 \\
\hline indirect savings & 2 & 2 & 2 & 2 & 3 & 3 & 2 & 1 & 2 & 2 & 2 & 2 \\
\hline direct \& indirect savings & 14 & 14 & 13 & 16 & 16 & 15 & 12 & 12 & 12 & 15 & 15 & 15 \\
\hline \multicolumn{13}{|l|}{$\phi=$ avg } \\
\hline base expenditure & 473 & 448 & 424 & 241 & 231 & 227 & 556 & 531 & 506 & 258 & 248 & 244 \\
\hline direct shade tree savings & 4 & 4 & 4 & 6 & 6 & 6 & 5 & 5 & 5 & 6 & 7 & 7 \\
\hline direct high albedo savings & 8 & 7 & 7 & 7 & 6 & 6 & 6 & 6 & 5 & 6 & 6 & 5 \\
\hline direct combined savings & 11 & 11 & 11 & 13 & 13 & 12 & 11 & 10 & 10 & 12 & 12 & 12 \\
\hline indirect savings & 2 & 2 & 2 & 2 & 3 & 2 & 2 & 2 & 2 & 2 & 2 & 2 \\
\hline direct $\&$ indirect savings & 13 & 13 & 13 & 15 & 15 & 14 & 12 & 11 & 11 & 14 & 14 & 14 \\
\hline
\end{tabular}


Table A.1.a(ii). Baton Rouge simulated cooling and heating annual electricity expenditures $\left[\$ / 1000 \mathrm{ft}^{2}\right]$, the direct savings [\%] from the strategic placement of shade trees and the use of high-albedo roofs, and the indirect savings [\%] from Heat Island Reduction (HIR) strategies for residential buildings. Base electricity expenditure is calculated for buildings without shade trees and with a dark roof (albedo 0.2). Direct savings are determined for buildings with 8 shade trees and a high-albedo roof (albedo 0.5). To estimate direct savings for other changes in albedo $(\Delta \mathrm{a})$ multiply the savings by the ratio $\Delta \mathrm{a} / 0.3$.

\begin{tabular}{|c|c|c|c|c|c|c|c|c|c|c|c|c|}
\hline \multirow{3}{*}{$\begin{array}{l}\text { building azimuth } \\
\qquad \& \\
\text { HIR strategy }\end{array}$} & \multicolumn{6}{|c|}{ gas heat } & \multicolumn{6}{|c|}{ electric heat } \\
\hline & \multirow[b]{2}{*}{$\mathrm{R}-7$} & \multicolumn{2}{|c|}{-1979} & \multicolumn{3}{|c|}{$1980+$} & \multicolumn{3}{|c|}{-1979} & \multicolumn{3}{|c|}{$1980+$} \\
\hline & & R-11 & R-19 & $\mathrm{R}-19$ & $\mathrm{R}-30$ & $\mathrm{R}-38$ & $\mathrm{R}-7$ & R-11 & R-19 & $\mathrm{R}-19$ & R-30 & $\mathrm{R}-38$ \\
\hline \multicolumn{13}{|l|}{$\phi=0$} \\
\hline base expenditure & 330 & 318 & 306 & 190 & 185 & 183 & 541 & 517 & 493 & 252 & 242 & 237 \\
\hline direct shade tree savings & 7 & 8 & 8 & 8 & 9 & 9 & 4 & 4 & 4 & 6 & 6 & 6 \\
\hline direct high albedo savings & 13 & 12 & 11 & 10 & 9 & 9 & 6 & 6 & 5 & 7 & 6 & 6 \\
\hline direct combined savings & 20 & 19 & 18 & 19 & 17 & 17 & 10 & 10 & 9 & 13 & 12 & 12 \\
\hline indirect savings & 4 & 4 & 4 & 4 & 4 & 4 & 2 & 2 & 2 & 2 & 2 & 2 \\
\hline direct $\&$ indirect savings & 23 & 23 & 22 & 21 & 20 & 20 & 11 & 11 & 11 & 14 & 14 & 13 \\
\hline \multicolumn{13}{|l|}{$\phi=90$} \\
\hline base expenditure & 344 & 331 & 318 & 199 & 193 & 191 & 565 & 539 & 513 & 264 & 253 & 249 \\
\hline direct shade tree savings & 10 & 10 & 10 & 12 & 11 & 11 & 6 & 6 & 5 & 8 & 8 & 8 \\
\hline direct high albedo savings & 12 & 11 & 10 & 10 & 8 & 8 & 6 & 5 & 5 & 6 & 6 & 5 \\
\hline direct combined savings & 22 & 21 & 20 & 20 & 19 & 19 & 11 & 11 & 10 & 13 & 13 & 13 \\
\hline indirect savings & 3 & 4 & 4 & 4 & 4 & 3 & 2 & 1 & 2 & 2 & 2 & 2 \\
\hline direct $\&$ indirect savings & 26 & 24 & 23 & 23 & 22 & 21 & 13 & 12 & 12 & 15 & 15 & 14 \\
\hline \multicolumn{13}{|l|}{$\phi=180$} \\
\hline base expenditure & 327 & 315 & 303 & 187 & 182 & 179 & 552 & 527 & 503 & 254 & 244 & 239 \\
\hline direct shade tree savings & 7 & 7 & 7 & 7 & 7 & 7 & 4 & 4 & 4 & 4 & 5 & 5 \\
\hline direct high albedo savings & 13 & 12 & 11 & 10 & 9 & 8 & 6 & 6 & 5 & 6 & 6 & 5 \\
\hline direct combined savings & 20 & 19 & 18 & 17 & 16 & 15 & 9 & 9 & 9 & 11 & 10 & 10 \\
\hline indirect savings & 4 & 4 & 4 & 4 & 3 & 3 & 2 & 2 & 1 & 2. & 2 & 2 \\
\hline direct $\&$ indirect savings & 23 & 22 & 21 & 20 & 19 & 18 & 11 & 10 & 10 & 12 & 12 & 12 \\
\hline \multicolumn{13}{|l|}{$\phi=270$} \\
\hline base expenditure & 346 & 333 & 321 & 200 & 195 & 193 & 564 & 539 & 515 & 264 & 254 & 250 \\
\hline direct shade tree savings & 10 & 10 & 10 & 11 & 11 & 11 & 6 & 6 & 6 & 8 & 8 & 8 \\
\hline direct high albedo savings & 12 & 11 & 10 & 10 & 8 & 8 & 6 & 5 & 5 & 6 & 6 & 6 \\
\hline direct combined savings & 22 & 21 & 20 & 20 & 19 & 19 & 11 & 11 & 10 & 13 & 13 & 13 \\
\hline indirect savings & 3 & 4 & 3 & 4 & 4 & 4 & 2 & 1 & 2 & 2 & 2 & 2 \\
\hline direct \& indirect savings & 25 & 24 & 23 & 23 & 22 & 22 & 12 & 12 & 12 & 15 & 15 & 15 \\
\hline \multicolumn{13}{|l|}{$\phi=\mathbf{a v g}$} \\
\hline base expenditure & 337 & 324 & 312 & 194 & 189 & 186 & 556 & 531 & 506 & 258 & 248 & 244 \\
\hline direct shade tree savings & 9 & 9 & 9 & 10 & 10 & 9 & 5 & 5 & 5 & 6 & 7 & 7 \\
\hline direct high albedo savings & 13 & 12 & 10 & 10 & 8 & 8 & 6 & 6 & 5 & 6 & 6 & 5 \\
\hline direct combined savings & 21 & 20 & 19 & 19 & 18 & 17 & 11 & 10 & 10 & 12 & 12 & 12 \\
\hline indirect savings & 4 & 4 & 4 & 4 & 4 & 3 & 2 & 2 & 2 & 2 & 2 & 2 \\
\hline direct \& indirect savings & 24 & 24 & 22 & 22 & 21 & 20 & 12 & 11 & 11 & 14 & 14 & 14 \\
\hline
\end{tabular}


Table A.1.a(iii). Baton Rouge simulated heating annual natural gas expenditures $\left[\$ / 1000 \mathrm{ft}^{2}\right]$, the direct savings [\%] from the strategic placement of shade trees and the use of high-albedo roofs, and the indirect savings [\%] from Heat Island Reduction (HIR) strategies for residential buildings. Base natural gas expenditure is calculated for buildings without shade trees and with a dark roof (albedo 0.2). Direct savings are determined for buildings with 8 shade trees and a high-albedo roof (albedo 0.5). To estimate direct savings for other changes in albedo $(\Delta \mathrm{a})$ multiply the savings by the ratio $\Delta \mathrm{a} / 0.3$.

\begin{tabular}{|c|c|c|c|c|c|c|}
\hline \multirow{3}{*}{$\begin{array}{c}\text { building azimuth } \\
\& \\
\text { HIR strategy }\end{array}$} & \multicolumn{6}{|c|}{ gas heat } \\
\hline & \multicolumn{3}{|c|}{-1979} & \multicolumn{3}{|c|}{$1980+$} \\
\hline & $\mathrm{R}-7$ & $\mathrm{R}-11$ & $\mathrm{R}-19$ & $\mathrm{R}-19$ & $\mathrm{R}-30$ & R-38 \\
\hline \multicolumn{7}{|l|}{$\phi=0$} \\
\hline base expenditure & 134 & 122 & 110 & 45 & 41 & 39 \\
\hline direct shade tree savings & -7 & -7 & -7 & -7 & -5 & -5 \\
\hline direct high albedo savings & -4 & -3 & -3 & -4 & -2 & -3 \\
\hline direct combined savings & -10 & -10 & -10 & -11 & -7 & -10 \\
\hline indirect savings & -2 & -2 & -3 & -2 & 0 & -3 \\
\hline direct \& indirect savings & -13 & -13 & -13 & -13 & -10 & -10 \\
\hline \multicolumn{7}{|l|}{$\phi=90$} \\
\hline base expenditure & 132 & 120 & 109 & 45 & 41 & 39 \\
\hline direct shade tree savings & -10 & -11 & -11 & -11 & -10 & -10 \\
\hline direct high albedo savings & -4 & -3 & -3 & -4 & -2 & -3 \\
\hline direct combined savings & -14 & -14 & -14 & -16 & -15 & -15 \\
\hline indirect savings & -2 & -2 & -2 & -2 & -2 & -3 \\
\hline direct \& indirect savings & -17 & -17 & -17 & -18 & -17 & -18 \\
\hline \multicolumn{7}{|l|}{$\phi=180$} \\
\hline base expenditure & 144 & 131 & 119 & 50 & 45 & 43 \\
\hline direct shade tree savings & -6 & -6 & -7 & -6 & -7 & -7 \\
\hline direct high albedo savings & -3 & -4 & -3 & -2 & -2 & -2 \\
\hline direct combined savings & -10 & -10 & -10 & -10 & -9 & -9 \\
\hline indirect savings & -2 & -2 & -3 & -2 & -2 & -2 \\
\hline direct $\&$ indirect savings & -13 & -13 & -13 & -12 & -13 & -12 \\
\hline \multicolumn{7}{|l|}{$\phi=\mathbf{2 7 0}$} \\
\hline base expenditure & 134 & 122 & 111 & 46 & 41 & 39 \\
\hline direct shade tree savings & -8 & -8 & -8 & -9 & -10 & -10 \\
\hline direct high albedo savings & -4 & -3 & -3 & -4 & -5 & -5 \\
\hline direct combined savings & -13 & -13 & -12 & -13 & -12 & -13 \\
\hline indirect savings & -2 & -2 & -2 & -2 & -2 & -3 \\
\hline direct \& indirect savings & -16 & -16 & -14 & -15 & -15 & -18 \\
\hline \multicolumn{7}{|l|}{$\phi=$ avg } \\
\hline base expenditure & 136 & 124 & 112 & 46 & 42 & 40 \\
\hline direct shade tree savings & -8 & -8 & -8 & -8 & -8 & -8 \\
\hline direct high albedo savings & -4 & -3 & -3 & -4 & -3 & -3 \\
\hline direct combined savings & -12 & -11 & -11 & -12 & -11 & -12 \\
\hline indirect savings & -2 & -2 & -2 & -2 & -2 & -3 \\
\hline direct \& indirect savings & -15 & -15 & -14 & -15 & -12 & -14 \\
\hline
\end{tabular}


Table A.1.a(iv). Baton Rouge simulated cooling peak power demand [ $\left.\mathrm{kW} / 1000 \mathrm{ft}^{2}\right]$, the direct savings [\%] from the strategic placement of shade trees and the use of high-albedo roofs, and the indirect savings [\%] from Heat Island Reduction (HIR) strategies for residential buildings. Base peak demand is calculated for buildings without shade trees and with a dark roof (albedo 0.2). Direct savings are determined for buildings with 8 shade trees and a high-albedo roof (albedo 0.5 ). To estimate direct savings for other changes in albedo $(\Delta \mathrm{a})$ multiply the savings by the ratio $\Delta \mathrm{a} / 0.3$.

\begin{tabular}{|c|c|c|c|c|c|c|}
\hline \multirow{3}{*}{$\begin{array}{l}\text { building azimuth } \\
\qquad \& \\
\text { HIR strategy }\end{array}$} & \multicolumn{6}{|c|}{ gas heat } \\
\hline & \multirow[b]{2}{*}{$\mathrm{R}-7$} & \multicolumn{2}{|l|}{-1979} & \multicolumn{3}{|c|}{$1980+$} \\
\hline & & $\mathrm{R}-11$ & R-19 & $R-19$ & $R-30$ & $\mathrm{R}-38$ \\
\hline \multicolumn{7}{|l|}{$\phi=0$} \\
\hline base expenditure & 3.30 & 3.31 & 3.32 & 1.89 & 1.88 & 1.88 \\
\hline direct shade tree savings & 6 & 6 & 6 & 17 & 17 & 17 \\
\hline direct high albedo savings & 8 & 8 & 8 & 6 & 6 & 6 \\
\hline direct combined savings & 14 & 14 & 14 & 24 & 24 & 24 \\
\hline indirect savings & 1 & 1 & 1 & 1 & 1 & 1 \\
\hline direct \& indirect savings & 15 & 15 & 15 & 14 & 14 & 14 \\
\hline \multicolumn{7}{|l|}{$\phi=90$} \\
\hline base expenditure & 3.61 & 3.62 & 3.61 & 2.09 & 2.08 & 2.08 \\
\hline direct shade tree savings & 11 & 11 & 10 & 12 & 12 & 12 \\
\hline direct high albedo savings & 8 & 8 & 7 & 6 & 6 & 6 \\
\hline direct combined savings & 18 & 18 & 18 & 18 & 18 & 18 \\
\hline indirect savings & 1 & 1 & 1 & 1 & 1 & 1 \\
\hline direct $\&$ indirect savings & 20 & 19 & 19 & 19 & 19 & 19 \\
\hline \multicolumn{7}{|l|}{$\phi=180$} \\
\hline base expenditure & 3.30 & 3.31 & 3.32 & 1.89 & 1.88 & 1.88 \\
\hline direct shade tree savings & 6 & 6 & 6 & 7 & 7 & 6 \\
\hline direct high albedo savings & 8 & 8 & 8 & 6 & 6 & 6 \\
\hline direct combined savings & 14 & 14 & 13 & 13 & 13 & 12 \\
\hline indirect savings & 1 & 1 & 1 & 1 & 1 & 1 \\
\hline direct $\&$ indirect savings & 15 & 15 & 15 & 14 & 14 & 14 \\
\hline \multicolumn{7}{|l|}{$\phi=270$} \\
\hline base expenditure & 3.42 & 3.43 & 3.44 & 1.97 & 1.96 & 1.96 \\
\hline direct shade tree savings & 8 & 8 & 8 & 9 & 9 & 9 \\
\hline direct high albedo savings & 8 & 8 & 8 & 6 & 6 & 6 \\
\hline direct combined savings & 16 & 15 & 15 & 15 & 14 & 14 \\
\hline indirect savings & 1 & 1 & 1 & 1 & 1 & 1 \\
\hline direct $\&$ indirect savings & 17 & 17 & 16 & 16 & 16 & 16 \\
\hline \multicolumn{7}{|l|}{$\phi=$ avg } \\
\hline base expenditure & 3.41 & 3.42 & 3.42 & 1.96 & 1.95 & 1.95 \\
\hline direct shade tree savings & 8 & 8 & 7 & 11 & 11 & 11 \\
\hline direct high albedo savings & 8 & 8 & 8 & 6 & 6 & 6 \\
\hline direct combined savings & 16 & 15 & 15 & 17 & 17 & 17 \\
\hline indirect savings & 1 & 1 & 1 & 1 & 1 & 1 \\
\hline direct $\&$ indirect savings & 17 & 17 & 16 & 16 & 18 & 15 \\
\hline
\end{tabular}


Table A.1.b(i). Baton Rouge simulated cooling and heating annual total energy expenditures [\$/1000 $\left.\mathrm{ft}^{2}\right]$, the direct savings [\%] from the strategic placement of shade trees and the use of high-albedo roofs, and the indirect savings [\%] from Heat Island Reduction (HIR) strategies for office buildings. Base energy expenditure is calculated for buildings without shade trees and with a dark roof (albedo 0.2). Direct savings are determined for buildings with 8 shade trees and a high-albedo roof (albedo 0.6). To estimate direct savings for other changes in albedo $(\Delta \mathrm{a})$ multiply the savings by the ratio $\Delta \mathrm{a} / 0.4$.

\begin{tabular}{|c|c|c|c|c|c|c|c|c|c|c|c|c|}
\hline \multirow{3}{*}{$\begin{array}{c}\text { building azimuth } \\
\& \\
\text { HIR strategy }\end{array}$} & \multicolumn{6}{|c|}{ gas heat } & \multicolumn{6}{|c|}{ electric heat } \\
\hline & \multicolumn{3}{|c|}{-1979} & \multicolumn{3}{|c|}{$1980+$} & \multicolumn{3}{|c|}{-1979} & \multicolumn{3}{|c|}{$1980+$} \\
\hline & $\mathrm{R}-7$ & $\mathrm{R}-11$ & $\mathrm{R}-19$ & $\mathrm{R}-19$ & $\mathrm{R}-30$ & $\mathrm{R}-38$ & $\mathrm{R}-7$ & $\mathrm{R}-11$ & $\mathrm{R}-19$ & R-19 & $\mathrm{R}-30$ & R-38 \\
\hline \multicolumn{13}{|l|}{$\phi=0$} \\
\hline base expenditure & 1029 & 1007 & 988 & 528 & 520 & 517 & 1041 & 1018 & 999 & 530 & 522 & 519 \\
\hline direct shade tree savings & 2 & 1 & 2 & 2 & 2 & 8 & 1 & 1 & 2 & 2 & 2 & 8 \\
\hline direct high albedo savings & $\cdot 7$ & 5 & 4 & 4 & 3 & 9 & 6 & 5 & 4 & 4 & 3 & 9 \\
\hline direct combined savings & 8 & 6 & 5 & 6 & 11 & 10 & 7 & 6 & 5 & 6 & 11 & 11 \\
\hline indirect savings & 2 & 2 & 2 & 2 & 2 & 8 & 2 & 2 & 2 & 2 & 2 & 8 \\
\hline direct $\&$ indirect savings & 10 & 8 & 7 & 13 & 12 & 12 & 9 & 8 & 7 & 13 & 12 & 12 \\
\hline \multicolumn{13}{|l|}{$\phi=90$} \\
\hline base expenditure & 1009 & 983 & 962 & 520 & 512 & 509 & 1022 & 995 & 974 & 522 & 514 & 510 \\
\hline direct shade tree savings & 5 & 4 & 4 & 4 & 4 & 4 & 5 & 4 & 4 & 4 & 4 & 3 \\
\hline direct high albedo savings & 7 & 5 & 4 & 4 & 3 & 3 & 7 & 5 & 4 & 4 & 3 & 3 \\
\hline direct combined savings & 11 & 9 & 8 & 8 & 7 & 6 & 11 & 9 & 7 & 8 & 7 & 6 \\
\hline indirect savings & 2 & 2 & 2 & 2 & 2 & 2 & 2 & 2 & 2 & 2 & 2 & 2 \\
\hline direct \& indirect savings & 13 & 11 & 9 & 10 & 9 & 8 & 12 & 11 & 9 & 10 & 9 & 8 \\
\hline \multicolumn{13}{|l|}{$\phi=\mathbf{a v g}$} \\
\hline base expenditure & 1019 & 995 & 975 & 524 & 516 & 513 & 1031 & 1006 & 986 & 526 & 518 & 514 \\
\hline direct shade tree savings & 3 & 3 & 3 & 3 & 3 & 6 & 3 & 3 & 3 & 3 & 3 & 6 \\
\hline direct high albedo savings & 7 & 5 & 4 & 4 & 3 & 6 & 6 & 5 & 4 & 4 & 3 & 6 \\
\hline direct combined savings & 9 & 8 & 6 & 7 & 6 & 8 & 9 & 8 & 6 & 7 & 6 & 8 \\
\hline indirect savings & 2 & 2 & 2 & 2 & 2 & 5 & 2 & 2 & 2 & 2 & 2 & 5 \\
\hline direct \& indirect savings & 11 & 10 & 8 & 12 & 11 & 10 & 11 & 9 & 8 & 12 & 11 & 10 \\
\hline
\end{tabular}


Table A.1.b(ii). Baton Rouge simulated cooling and heating annual electricity expenditures $\left[\$ / 1000 \mathrm{ft}^{2}\right]$, the direct savings [\%] from the strategic placement of shade trees and the use of high-albedo roofs, and the indirect savings [\%] from Heat Island Reduction (HIR) strategies for office buildings. Base electricity expenditure is calculated for buildings without shade trees and with a dark roof (albedo 0.2). Direct savings are determined for buildings with 8 shade trees and a high-albedo roof (albedo 0.6). To estimate direct savings for other changes in albedo $(\Delta \mathrm{a})$ multiply the savings by the ratio $\Delta \mathrm{a} / 0.4$.

\begin{tabular}{|c|c|c|c|c|c|c|c|c|c|c|c|c|}
\hline \multirow{3}{*}{$\begin{array}{c}\text { building azimuth } \\
\& \\
\text { HIR strategy }\end{array}$} & \multicolumn{6}{|c|}{ gas heat } & \multicolumn{6}{|c|}{ electric heat } \\
\hline & \multicolumn{3}{|c|}{-1979} & \multicolumn{3}{|c|}{$1980+$} & \multicolumn{3}{|c|}{-1979} & \multicolumn{3}{|c|}{$1980_{+}^{+}$} \\
\hline & R-7 & $\mathrm{R}-11$ & R-19 & R-19 & $\mathrm{R}-30$ & R-38 & $\mathrm{R}-7$ & R-11 & R-19 & R-19 & $\mathrm{R}-30$ & $\mathrm{R}-38$ \\
\hline \multicolumn{13}{|l|}{$\phi=0$} \\
\hline base expenditure & 975 & 958 & 942 & 515 & 509 & 507 & 1041 & 1018 & 999 & 530 & 522 & 519 \\
\hline direct shade tree savings & 2 & 2 & 2 & 2 & 2 & 8 & 1 & 1 & 2 & 2 & 2 & 8 \\
\hline direct high albedo savings & 7 & 6 & 4 & 4 & 4 & 9 & 6 & 5 & 4 & 4 & 3 & 9 \\
\hline direct combined savings & 9 & 7 & 6 & 6 & 11 & 11 & 7 & 6 & 5 & 6 & 11 & 11 \\
\hline indirect savings & 2 & 2 & 2 & 2 & 2 & 8 & 2 & 2 & 2 & 2 & 2 & 8 \\
\hline direct \& indirect savings & 11 & 9 & 8 & 14 & 13 & 13 & 9 & 8 & 7 & 13 & 12 & 12 \\
\hline$\phi=90$ & & & & & & & & & & & & \\
\hline base expenditure & 952 & 932 & 915 & 507 & 501 & 498 & 1022 & 995 & 974 & 522 & 514 & 510 \\
\hline direct shade tree savings & 5 & 5 & 4 & 4 & 4 & 4 & 5 & 4 & 4 & 4 & 4 & 3 \\
\hline direct high albedo savings & 7 & 6 & 4 & 5 & 4 & 3 & 7 & 5 & 4 & 4 & 3 & 3 \\
\hline direct combined savings & 12 & 10 & 8 & 8 & 7 & 7 & 11 & 9 & 7 & 8 & 7 & 6 \\
\hline indirect savings & 2 & 2 & 2 & 2 & 2 & 2 & 2 & 2 & 2 & 2 & 2 & 2 \\
\hline direct \& indirect savings & 14 & 12 & 10 & 10 & 9 & 9 & 12 & 11 & 9 & 10 & 9 & 8 \\
\hline $\begin{array}{l}\Psi-\mathbf{a} \mathbf{g} \\
\text { base expenditure }\end{array}$ & 964 & 945 & 928 & 511 & 605 & 500 & 1031 & 1006 & 086 & 526 & 518 & 514 \\
\hline direct shade tree savings & 3 & 3 & 3 & 3 & 3 & 6 & 3 & 3 & 3 & 3 & 3 & 6 \\
\hline direct high albedo savings & 7 & 6 & 4 & 5 & 4 & 6 & 6 & 5 & 4 & 4 & 3 & 6 \\
\hline direct combined savings & 10 & 8 & 7 & 7 & 6 & 9 & 9 & 8 & 6 & 7 & 9 & 8 \\
\hline indirect savings & 2 & 2 & 2 & 2 & 2 & 5 & 2 & 2 & 2 & 2 & 2 & 5 \\
\hline direct \& indirect savings & 12 & 10 & 9 & 12 & 11 & 11 & 11 & 9 & 8 & 12 & 11 & 10 \\
\hline
\end{tabular}


Table A.1.b(iii). Baton Rouge simulated heating annual natural gas expenditures $\left[\$ / 1000 \mathrm{ft}^{2}\right]$, the direct savings [\%] from the strategic placement of shade trees and the use of high-albedo roofs, and the indirect savings [\%] from Heat Island Reduction (HIR) strategies for office buildings. Base natural gas expenditure is calculated for buildings without shade trees and with a dark roof (albedo 0.2). Direct savings are determined for buildings with 8 shade trees and a high-albedo roof (albedo 0.6). To estimate direct savings for other changes in albedo $(\Delta a)$ multiply the savings by the ratio $\Delta \mathrm{a} / 0.4$.

\begin{tabular}{|c|c|c|c|c|c|c|}
\hline \multirow{3}{*}{\begin{tabular}{|c} 
building azimuth \\
$\&$ \\
HIR strategy
\end{tabular}} & \multicolumn{6}{|c|}{ gas heat } \\
\hline & & -1979 & & & $1980+$ & \\
\hline & R-7 & $\mathrm{R}-11$ & R-19 & R-19 & $\mathrm{R}-30$ & $\mathrm{R}-38$ \\
\hline \multicolumn{7}{|l|}{$\phi=0$} \\
\hline base expenditure & 54 & 49 & 45 & 12 & 11 & 11 \\
\hline direct shade tree savings & -2 & -2 & -2 & 0 & 0 & 0 \\
\hline direct high albedo savings & -6 & -6 & -4 & -8 & -9 & 0 \\
\hline direct combined savings & -7 & -8 & -7 & -17 & -9 & -9 \\
\hline indirect savings & 0 & -2 & -2 & 0 & 0 & 0 \\
\hline direct \& indirect savings & -9 & -8 & -7 & -17 & -9 & -9 \\
\hline \multicolumn{7}{|l|}{$\phi=90$} \\
\hline base expenditure & 56 & 52 & 47 & 12 & 11 & 11 \\
\hline direct shade tree savings & -2 & 2 & 0 & -8 & -9 & 0 \\
\hline direct high albedo savings & -5 & -4 & -4 & -17 & -9 & -9 \\
\hline direct combined savings & -5 & -4 & -4 & -17 & -9 & -9 \\
\hline indirect savings & -2 & 0 & -2 & -8 & -9 & 0 \\
\hline direct \& indirect savings & -7 & -4 & -4 & -17 & -18 & -9 \\
\hline \multicolumn{7}{|l|}{$\phi=\mathbf{a v g}$} \\
\hline base expenditure & 55 & 50 & 46 & 12 & 11 & 11 \\
\hline direct shade tree savings & -2 & -2 & -1 & -4 & -5 & 0 \\
\hline direct high albedo savings & -5 & -8 & -4 & -12 & -9 & -5 \\
\hline direct combined savings & -6 & -6 & -5 & -17 & -9 & -9 \\
\hline indirect savings & -1 & -1 & -2 & -4 & -5 & 0 \\
\hline direct \& indirect savings & -8 & -8 & -5 & -17 & -14 & -9 \\
\hline
\end{tabular}


Table A.1.b(iv). Baton Rouge simulated cooling peak power demand $\left[\mathrm{kW} / 1000 \mathrm{ft}^{2}\right]$, the direct savings [\%] from the strategic placement of shade trees and the use of high-albedo roofs, and the indirect savings [\%] from Heat Island Reduction (HIR) strategies for office buildings. Base peak demand is calculated for buildings without shade trees and with a dark roof (albedo 0.2). Direct savings are determined for buildings with 8 shade trees and a high-albedo roof (albedo 0.6). To estimate direct savings for other changes in albedo $(\Delta \mathrm{a})$ multiply the savings by the ratio $\Delta \mathrm{a} / 0.4$.

\begin{tabular}{|c|c|c|c|c|c|c|}
\hline \multirow{3}{*}{$\begin{array}{l}\text { building azimuth } \\
\qquad \& \\
\text { HIR strategy }\end{array}$} & \multicolumn{6}{|c|}{ gas heat } \\
\hline & \multicolumn{3}{|c|}{-1979} & \multicolumn{3}{|c|}{$1980+$} \\
\hline & R-7 & R-11 & R-19 & $\mathrm{R}-19$ & $\mathrm{R}-30$ & $\mathrm{R}-38$ \\
\hline \multicolumn{7}{|l|}{$\phi=0$} \\
\hline base expenditure & 8.00 & 7.81 & 7.64 & 4.58 & 4.49 & 4.45 \\
\hline direct shade tree savings & -1 & -1 & 1 & 1 & 1 & 20 \\
\hline direct high albedo savings & 5 & 4 & 3 & 4 & 3 & 22 \\
\hline direct combined savings & 5 & 4 & 4 & 5 & 23 & 22 \\
\hline indirect savings & 3 & 3 & 3 & 3 & 3 & 21 \\
\hline direct \& indirect savings & 8 & 7 & 7 & 25 & 24 & 24 \\
\hline \multicolumn{7}{|l|}{$\phi=90$} \\
\hline base expenditure & 8.03 & 7.80 & 7.62 & 4.55 & 4.46 & 4.42 \\
\hline direct shade tree savings & 5 & 4 & 1 & 3 & -1 & -1 \\
\hline direct high albedo savings & 5 & 4 & 3 & 4 & 3 & 2 \\
\hline direct combined savings & 7 & 5 & 4 & 3 & 1 & 1 \\
\hline indirect savings & 3 & 3 & 3 & 3 & 3 & 3 \\
\hline direct $\&$ indirect savings & 10 & 8 & 7 & 6 & 4 & 4 \\
\hline \multicolumn{7}{|l|}{$\phi=\mathbf{a v g}$} \\
\hline base expenditure & 8.02 & 7.81 & 7.63 & 4.56 & 4.47 & 4.44 \\
\hline direct shade tree savings & 2 & 1 & 1 & 2 & 1 & 9 \\
\hline direct high albedo savings & 5 & 3 & 3 & 4 & 3 & 12 \\
\hline direct combined savings & 6 & 4 & 4 & 4 & 4 & 12 \\
\hline indirect savings & 3 & 3 & 3 & 3 & 3 & 12 \\
\hline direct \& indirect savings & 9 & 8 & 7 & 15 & 7 & 14 \\
\hline
\end{tabular}


Table A.1.c(i). Baton Rouge simulated cooling and heating annual total energy expenditures $\left[\$ / 1000 \mathrm{ft}^{2}\right]$, the direct savings [\%] from the strategic placement of shade trees and the use of high-albedo roofs, and the indirect savings [\%] from Heat Island Reduction (HIR) strategies for retail buildings. Base energy expenditure is calculated for buildings without shade trees and with a dark roof (albedo 0.2). Direct savings are determined for buildings with 4 shade trees and a high-albedo roof (albedo 0.6). To estimate direct savings for other changes in albedo $(\Delta \mathrm{a})$ multiply the savings by the ratio $\Delta \mathrm{a} / 0.4$.

\begin{tabular}{|c|c|c|c|c|c|c|c|c|c|c|c|c|}
\hline \multirow{3}{*}{$\begin{array}{c}\text { building azimuth } \\
\& \\
\text { HIR strategy }\end{array}$} & \multicolumn{6}{|c|}{ gas heat } & \multicolumn{6}{|c|}{ electric heat } \\
\hline & \multicolumn{3}{|c|}{-1979} & \multicolumn{3}{|c|}{$1980+$} & \multicolumn{3}{|c|}{-1979} & \multicolumn{3}{|c|}{$1980+$} \\
\hline & R-7 & $\mathrm{R}-11$ & R-19 & R-19 & R-30 & $\mathrm{R}-38$ & $\mathrm{R}-7$ & R-11 & R-19 & R-19 & $\mathrm{R}-30$ & R-38 \\
\hline \multicolumn{13}{|l|}{$\phi=0$} \\
\hline base expenditure & 987 & 960 & 934 & 446 & 437 & 423 & 990 & 962 & 936 & 446 & 437 & 423 \\
\hline direct shade tree savings & 1 & 1 & 6 & 5 & 4 & 1 & 1 & 1 & 6 & 5 & 4 & 1 \\
\hline direct high albedo savings & 10 & 8 & 6 & 10 & 8 & 4 & 10 & 8 & 6 & 10 & 8 & 4 \\
\hline direct combined savings & 11 & 9 & 11 & 11 & 9 & 5 & 11 & 9 & 11 & 11 & 9 & 5 \\
\hline indirect savings & 1 & 1 & 1 & 2 & 2 & 2 & 1 & 1 & 1 & 2 & 2 & 2 \\
\hline direct $\&$ indirect savings & 12 & 15 & 12 & 13 & 11 & 7 & 12 & 15 & 12 & 13 & 11 & 7 \\
\hline \multicolumn{13}{|l|}{$\phi=90$} \\
\hline base expenditure & 1021 & 990 & 967 & 462 & 457 & 454 & 1026 & 994 & 970 & 462 & 457 & 454 \\
\hline direct shade tree savings & 5 & 5 & 6 & 6 & 6 & 6 & 5 & 5 & 6 & 6 & 6 & 6 \\
\hline direct high albedo savings & 9 & 6 & 5 & 6 & 5 & 4 & 9 & 7 & 5 & 6 & 5 & 4 \\
\hline direct combined savings & 14 & 12 & 11 & 12 & 11 & 11 & 14 & 12 & 11 & 12 & 11 & 11 \\
\hline indirect savings & 1 & 1 & 1 & 2 & 2 & 2 & 1 & 1 & 1 & 2 & 2 & 2 \\
\hline direct \& indirect savings & 15 & 14 & 12 & 13 & 13 & 12 & 15 & 13 & 12 & 13 & 13 & 12 \\
\hline \multicolumn{13}{|l|}{$\phi=270$} \\
\hline base expenditure & 1001 & 969 & 937 & 450 & 439 & 435 & 1005 & 972 & 940 & 450 & 439 & 435 \\
\hline direct shade tree savings & 5 & 5 & 5 & 5 & 5 & 5 & 5 & 5 & 5 & 5 & 5 & 5 \\
\hline direct high albedo savings & 10 & 8 & 6 & 7 & 6 & 5 & 10 & 8 & 6 & 7 & 6 & 5 \\
\hline direct combined savings & 15 & 13 & 11 & 13 & 10 & 9 & 15 & 13 & 11 & 12 & 10 & 9 \\
\hline indirect savings & 1 & 2 & 1 & 2 & 2 & 2 & 1 & 1 & 1 & 2 & 2 & 2 \\
\hline direct \& indirect savings & 16 & 15 & 12 & 14 & 12 & 11 & 16 & 14 & 12 & 14 & 12 & 11 \\
\hline \multicolumn{13}{|l|}{$\phi=$ avg } \\
\hline base expenditure & 1003 & 973 & 946 & 453 & 444 & 437 & 1007 & 976 & 949 & 453 & 444 & 437 \\
\hline direct shade tree savings & 3 & 4 & 6 & 5 & 5 & 4 & 3 & 4 & 6 & 5 & 5 & 4 \\
\hline direct high albedo savings & 10 & 8 & 6 & 8 & 6 & 4 & 9 & 7 & 6 & 8 & 6 & 4 \\
\hline direct combined savings & 13 & 12 & 11 & 12 & 10 & 9 & 13 & 12 & 11 & 12 & 10 & 9 \\
\hline indirect savings & 1 & 1 & 1 & 2 & 2 & 2 & 1 & 1 & 1 & 2 & 2 & 2 \\
\hline direct $\&$ indirect savings & 15 & 14 & 12 & 13 & 12 & 10 & 15 & 14 & 12 & 13 & 12 & 10 \\
\hline
\end{tabular}


Table A.1.c(ii). Baton Rouge simulated cooling and heating annual electricity expenditures [ $\$ / 1000 \mathrm{ft}^{2}$ ], the direct savings [\%] from the strategic placement of shade trees and the use of high-albedo roofs, and the indirect savings [\%] from Heat Island Reduction (HIR) strategies for retail buildings. Base electricity expenditure is calculated for buildings without shade trees and with a dark roof (albedo 0.2). Direct savings are determined for buildings with 4 shade trees and a high-albedo roof (albedo 0.6). To estimate direct savings for other changes in albedo $(\Delta \mathrm{a})$ multiply the savings by the ratio $\Delta \mathrm{a} / 0.4$.

\begin{tabular}{|c|c|c|c|c|c|c|c|c|c|c|c|c|}
\hline \multirow{3}{*}{$\begin{array}{c}\text { building azimuth } \\
\text { \& } \\
\text { HIR strategy }\end{array}$} & \multicolumn{6}{|c|}{ gas heat } & \multicolumn{6}{|c|}{ electric heat } \\
\hline & \multicolumn{3}{|c|}{-1979} & \multicolumn{3}{|c|}{$1980+$} & \multicolumn{3}{|c|}{-1979} & \multicolumn{3}{|c|}{$1980+$} \\
\hline & $\mathrm{R}-7$ & R-11 & $\mathrm{R}-19$ & $\mathrm{R}-19$ & R-30 & R-38 & R-7 & R-11 & $\mathrm{R}-19$ & R-19 & $\mathrm{R}-30$ & R-38 \\
\hline$\phi=0$ & & & & & & & & & & & & \\
\hline base expenditure & 975 & 952 & 929 & 446 & 437 & 423 & 990 & 962 & 936 & 446 & 437 & 423 \\
\hline direct shade tree savings & 1 & 1 & 6 & 5 & 4 & 1 & 1 & 1 & 6 & 5 & 4 & 1 \\
\hline direct high albedo savings & 10 & 8 & 6 & 10 & 8 & 4 & 10 & 8 & 6 & 10 & 8 & 4 \\
\hline direct combined savings & 11 & 9 & 11 & 11 & 9 & 5 & 11 & 9 & 11 & 11 & 9 & 5 \\
\hline indirect savings & 1 & 1 & 1 & 2 & 2 & 2 & 1 & 1 & 1 & 2 & 2 & 2 \\
\hline direct \& indirect savings & 12 & 15 & 12 & 13 & 11 & 7 & 12 & 15 & 12 & 13 & 11 & 7 \\
\hline$\phi=90$ & & & & & & & & & & & & \\
\hline base expenditure & 1003 & 978 & 958 & 462 & 456 & 454 & 1026 & 994 & 970 & 462 & 457 & 454 \\
\hline direct shade tree savings & 5 & 5 & 6 & 6 & 6 & 6 & 5 & 5 & 6 & 6 & 6 & 6 \\
\hline direct high albedo savings & 9 & 7 & 5 & 6 & 5 & 4 & 9 & 7 & 5 & 6 & 5 & 4 \\
\hline direct combined savings & 15 & 13 & 11 & 12 & 11 & 11 & 14 & 12 & 11 & 12 & 11 & 11 \\
\hline indirect savings & 1 & 1 & 1 & 2 & 2 & 2 & 1 & 1 & 1 & 2 & 2 & 2 \\
\hline direct \& indirect savings & 16 & 14 & 12 & 13 & 13 & 12 & 15 & 13 & 12 & 13 & 13 & 12 \\
\hline$\phi=\mathbf{2 7 0}$ & & & & & & & & & & & & \\
\hline base expenditure & 986 & 958 & 929 & 449 & 439 & 435 & 1005 & 972 & 940 & 450 & 439 & 435 \\
\hline direct shade tree savings & 5 & 5 & 5 & 5 & 5 & 5 & 5 & 5 & 5 & 5 & 5 & 5 \\
\hline direct high albedo savings & 10 & 8 & 6 & 7 & 6 & 5 & 10 & 8 & 6 & 7 & 6 & 5 \\
\hline direct combined savings & 15 & 13 & 11 & 12 & 10 & 9 & 15 & 13 & 11 & 12 & 10 & 9 \\
\hline indirect savings & 2 & 2 & 1 & 2 & 2 & 2 & 1 & 1 & 1 & 2 & 2 & 2 \\
\hline direct \& indirect savings & 17 & 15 & 12 & 14 & 12 & 11 & 16 & 14 & 12 & 14 & 12 & 11 \\
\hline$\phi=$ avg & & & & & & & & & & & & \\
\hline base expenditure & 988 & 963 & 939 & 452 & 444 & 437 & 1007 & 976 & 949 & 453 & 444 & 437 \\
\hline direct shade tree savings & 4 & 4 & 6 & 5 & 5 & 4 & 3 & 4 & 6 & 5 & 5 & 4 \\
\hline direct high albedo savings & 10 & 8 & 6 & 8 & 6 & 4 & 9 & 7 & 6 & 8 & 6 & 4 \\
\hline direct combined savings & 14 & 12 & 11 & 12 & 10 & 9 & 13 & 12 & 11 & 12 & 10 & 9 \\
\hline indirect savings & 2 & 1 & 1 & 2 & 2 & 2 & 1 & 1 & 1 & 2 & 2 & 2 \\
\hline direct \& indirect savings & 15 & 15 & 12 & 13 & 12 & 10 & 15 & 14 & 12 & 13 & 12 & 10 \\
\hline
\end{tabular}


Table A.1.c(iii). Baton Rouge simulated heating annual natural gas expenditures $\left[\$ / 1000 \mathrm{ft}^{2}\right]$, the direct savings [\%] from the strategic placement of shade trees and the use of high-albedo roofs, and the indirect savings [\%] from Heat Island Reduction (HIR) strategies for retail buildings. Base natural gas expenditure is calculated for buildings without shade trees and with a dark roof (albedo 0.2). Direct savings are determined for buildings with 4 shade trees and a high-albedo roof (albedo 0.6). To estimate direct savings for other changes in albedo $(\Delta \mathrm{a})$ multiply the savings by the ratio $\Delta \mathrm{a} / 0.4$.

\begin{tabular}{|c|c|c|c|c|c|c|}
\hline & & & & heat & & \\
\hline & & -1979 & & & $1980+$ & \\
\hline HIR strategy & R-7 & R-11 & R-19 & R-19 & R-30 & R-38 \\
\hline$\phi=\mathbf{0}$ & & & & & & \\
\hline base expenditure & 12 & 8 & 5 & 0 & 0 & 0 \\
\hline direct shade tree savings & 0 & 0 & 0 & 0 & 0 & 0 \\
\hline direct high albedo savings & 0 & -12 & -20 & 0 & 0 & 0 \\
\hline direct combined savings & -8 & -12 & -20 & 0 & 0 & 0 \\
\hline indirect savings & 0 & 0 & 0 & 0 & 0 & 0 \\
\hline direct \& indirect savings & -8 & -12 & -20 & 0 & 0 & 0 \\
\hline$\phi=90$ & & & & & & \\
\hline base expenditure & 18 & 12 & 9 & 0 & 0 & 0 \\
\hline direct shade tree savings & 6 & 0 & 11 & 0 & 0 & 0 \\
\hline direct high albedo savings & -11 & -17 & 0 & 0 & 0 & 0 \\
\hline direct combined savings & -6 & -8 & 0 & 0 & 0 & 0 \\
\hline indirect savings & 0 & -8 & 0 & 0 & 0 & 0 \\
\hline direct $\&$ indirect savings & -6 & -17 & 0 & 0 & 0 & 0 \\
\hline$\phi=270$ & & & & & & \\
\hline base expenditure & 15 & 11 & 8 & 0 & 0 & 0 \\
\hline direct shade tree savings & 0 & 0 & 0 & 0 & 0 & 0 \\
\hline direct high albedo savings & -13 & -9 & 0 & 0 & 0 & 0 \\
\hline direct combined savings & -13 & -9 & 0 & 0 & 0 & 0 \\
\hline indirect savings & -7 & 0 & 0 & 0 & 0 & 0 \\
\hline direct $\&$ indirect savings & -13 & -9 & 0 & 0 & 0 & 0 \\
\hline$\phi=\mathbf{a v g}$ & & & & & & \\
\hline base expenditure & 15 & 10 & 7 & 0 & 0 & 0 \\
\hline direct shade tree savings & 2 & 0 & 5 & 0 & 0 & 0 \\
\hline direct high albedo savings & -9 & -13 & -5 & 0 & 0 & 0 \\
\hline direct combined savings & -9 & -20 & -5 & 0 & 0 & 0 \\
\hline indirect savings & -2 & -3 & 0 & 0 & 0 & 0 \\
\hline direct \& indirect savings & -9 & -20 & -5 & 0 & 0 & 0 \\
\hline
\end{tabular}


Table A.1.c(iv). Baton Rouge simulated cooling peak power demand $\left[\mathrm{kW} / 1000 \mathrm{ft}^{2}\right]$, the direct savings [\%] from the strategic placement of shade trees and the use of high-albedo roofs, and the indirect savings [\%] from Heat Island Reduction (HIR) strategies for retail buildings. Base peak demand is calculated for buildings without shade trees and with a dark roof (albedo 0.2). Direct savings are determined for buildings with 4 shade trees and a high-albedo roof (albedo 0.6). To estimate direct savings for other changes in albedo $(\Delta \mathrm{a})$ multiply the savings by the ratio $\Delta \mathrm{a} / 0.4$.

\begin{tabular}{|c|c|c|c|c|c|c|}
\hline \multirow{3}{*}{$\begin{array}{c}\text { building azimuth } \\
\& \\
\text { HIR strategy }\end{array}$} & \multicolumn{6}{|c|}{ gas heat } \\
\hline & \multicolumn{3}{|c|}{-1979} & \multicolumn{3}{|c|}{$1980+$} \\
\hline & $\mathrm{R}-7$ & R-11 & R-19 & $R-19$ & R-30 & R-38 \\
\hline$\phi=0$. & & & & & & \\
\hline base expenditure & 4.87 & 4.64 & 4.41 & 2.43 & 2.33 & 2.11 \\
\hline direct shade tree savings & -8 & -7 & 11 & 10 & 9 & 0 \\
\hline direct high albedo savings & 10 & 8 & 6 & 16 & 13 & 4 \\
\hline direct combined savings & 2 & 1 & 16 & 16 & 13 & 4 \\
\hline indirect savings & 2 & 2 & 2 & 2 & 2 & 2 \\
\hline direct \& indirect savings & 4 & 21 & 17 & 17 & 15 & 6 \\
\hline$\phi=90$ & & & & & & \\
\hline base expenditure & 5.71 & 5.40 & 5.16 & 2.88 & 2.88 & 2.85 \\
\hline direct shade tree savings & 5 & 6 & 8 & 6 & 9 & 9 \\
\hline direct high albedo savings & 7 & 4 & 2 & 3 & 4 & 4 \\
\hline direct combined savings & 14 & 11 & 10 & 11 & 13 & 13 \\
\hline indirect savings & 2 & 1 & 1 & 1 & 1 & 1 \\
\hline direct \& indirect savings & 15 & 12 & 11 & 12 & 14 & 14 \\
\hline$\phi=\mathbf{2 7 0}$ & & & & & & \\
\hline base expenditure & 5.52 & 5.22 & 4.93 & 2.72 & 2.60 & 2.56 \\
\hline direct shade tree savings & 5 & 5 & 6 & 6 & 1 & 1 \\
\hline direct high albedo savings & 10 & 8 & 6 & 7 & 5 & 5 \\
\hline direct combined savings & 15 & 13 & 11 & 13 & 7 & 6 \\
\hline indirect savings & 2 & 2 & 2 & 2 & 2 & 2 \\
\hline direct \& indirect savings & 17 & 15 & 11 & 10 & 8 & 7 \\
\hline$\phi=$ avg & & & & & & \\
\hline base expenditure & 5.37 & 5.09 & 4.83 & 2.68 & 2.60 & 2.51 \\
\hline direct shade tree savings & 1 & 2 & 8 & 7 & 2 & 4 \\
\hline direct high albedo savings & 9 & 7 & 5 & 8 & 7 & 4 \\
\hline direct combined savings & 11 & 9 & 12 & 13 & 11 & 8 \\
\hline indirect savings & 2 & 2 & 1 & 1 & 2 & 2 \\
\hline direct \& indirect savings & 12 & 11 & 13 & 13 & 12 & 9 \\
\hline
\end{tabular}


Table A.2.a(i). Sacramento simulated cooling and heating annual total energy expenditures $\left[\$ / 1000 \mathrm{ft}^{2}\right]$, the direct savings [\%] from the strategic placement of shade trees and the use of high-albedo roofs, and the indirect savings [\%] from Heat Island Reduction (HIR) strategies for residential buildings. Base energy expenditure is calculated for buildings without shade trees and with a dark roof (albedo 0.2). Direct savings are determined for buildings with 8 shade trees and a high-albedo roof (albedo 0.5 ). To estimate direct savings for other changes in albedo $(\Delta \mathrm{a})$ multiply the savings by the ratio $\Delta \mathrm{a} / 0.3$.

\begin{tabular}{|c|c|c|c|c|c|c|c|c|c|c|c|c|}
\hline \multirow{3}{*}{$\begin{array}{c}\text { building azimuth } \\
\& \\
\text { HIR strategy }\end{array}$} & \multicolumn{6}{|c|}{ gas heat } & \multicolumn{6}{|c|}{ electric heat } \\
\hline & \multicolumn{3}{|c|}{-1979} & \multicolumn{3}{|c|}{$1980+$} & \multicolumn{3}{|c|}{-1979} & \multicolumn{3}{|c|}{$1980+$} \\
\hline & R-7 & $\mathrm{R}-11$ & $R-19$ & R-19 & R-30 & R-38 & R-7 & $\mathrm{R}-11$ & R-19 & R-19 & R-30 & R-38 \\
\hline \multicolumn{13}{|l|}{$\phi=0$} \\
\hline base expenditure & 429 & 392 & 356 & 177 & 162 & 156 & 681 & 636 & 590 & 235 & 216 & 209 \\
\hline direct shade tree savings & 1 & 2 & 2 & 4 & 4 & 4 & 1 & 1 & 0 & 3 & 3 & 3 \\
\hline direct high albedo savings & 5 & 5 & 4 & 6 & 5 & 4 & 2 & 2 & 1 & 3 & 3 & 3 \\
\hline direct combined savings & 6 & 6 & 5 & 8 & 9 & 8 & 2 & 2 & 1 & 5 & 5 & 5 \\
\hline indirect savings & 1 & 2 & 1 & 3 & 2 & 2 & 1 & 1 & 0 & 2 & 1 & 1 \\
\hline direct \& indirect savings & 6 & 6 & 5 & 9 & 9 & 9 & 3 & 2 & 1 & 6 & 5 & 5 \\
\hline \multicolumn{13}{|l|}{$\phi=90$} \\
\hline base expenditure & 448 & 412 & 378 & 191 & 176 & 170 & 716 & 672 & 627 & 255 & 237 & 229 \\
\hline direct shade tree savings & 2 & 2 & 3 & 6 & 7 & 7 & 2 & 2 & 1 & 5 & 5 & 5 \\
\hline direct high albedo savings & 5 & 5 & 4 & 5 & 5 & 4 & 1 & 1 & 1 & 3 & 3 & 2 \\
\hline direct combined savings & 6 & 6 & 7 & 10 & 10 & 10 & 3 & 2 & 2 & 6 & 7 & 7 \\
\hline indirect savings & 2 & 2 & 2 & 3 & 3 & 3 & 1 & 1 & 0 & 2 & 2 & 1 \\
\hline direct \& indirect savings & 6 & 7 & 7 & 11 & 11 & 11 & 3 & 2 & 1 & 7 & 7 & 7 \\
\hline \multicolumn{13}{|l|}{$\phi=180$} \\
\hline base expenditure & 441 & 404 & 368 & 183 & 168 & 162 & 705 & 660 & 615 & 245 & 226 & 218 \\
\hline direct shade tree savings & 1 & 1 & 1 & 3 & 4 & 4 & 1 & 1 & 0 & 2 & 2 & 2 \\
\hline direct high albedo savings & 5 & 4 & 4 & 5 & 5 & 4 & 1 & 1 & 1 & 2 & 2 & 2 \\
\hline direct combined savings & 5 & 5 & 5 & 7 & 7 & 7 & 2 & 1 & 0 & 4 & 3 & 3 \\
\hline indirect savings & 1 & 1 & 1 & 2 & 2 & 2 & 1 & 0 & 0 & 1 & 1 & 1 \\
\hline direct \& indirect savings & 5 & 4 & 4 & 8 & 8 & 7 & 1 & 0 & 0 & 4 & 3 & 3 \\
\hline \multicolumn{13}{|l|}{$\phi=270$} \\
\hline base expenditure & 444 & 409 & 375 & 188 & 174 & 168 & 706 & 662 & 617 & 250 & 231 & 224 \\
\hline direct shade tree savings & 2 & 3 & 3 & 6 & 6 & 7 & 1 & 1 & 1 & 4 & 4 & 4 \\
\hline direct high albedo savings & 5 & 5 & 4 & 5 & 5 & 5 & 1 & 1 & 1 & 3 & 2 & 2 \\
\hline direct combined savings & 6 & 7 & 7 & 10 & 10 & 10 & 2 & 1 & 1 & 6 & 5 & 5 \\
\hline indirect savings & 1 & 2 & 2 & 3 & 3 & 3 & 1 & 1 & 0 & 2 & 2 & 2 \\
\hline direct \& indirect savings & 6 & 7 & 7 & 11 & 11 & 11 & 2 & 1 & 0 & 6 & 5 & 5 \\
\hline \multicolumn{13}{|l|}{$\phi=$ avg } \\
\hline base expenditure & 440 & 404 & 369 & 185 & 170 & 164 & 702 & 658 & 612 & 246 & 227 & 220 \\
\hline direct shade tree savings & 1 & 2 & 2 & 5 & 4 & 5 & 1 & 1 & 1 & 3 & 2 & 4 \\
\hline direct high albedo savings & 5 & 5 & 4 & 5 & 5 & 4 & 1 & 1 & 1 & 3 & 2 & 2 \\
\hline direct combined savings & 6 & 6 & 6 & 9 & 9 & 9 & 2 & 2 & 1 & 5 & 4 & 5 \\
\hline indirect savings & 1 & 2 & 2 & 3 & 3 & 3 & 1 & 1 & 0 & 2 & 1 & 1 \\
\hline direct \& indirect savings & 6 & 6 & 6 & 10 & 10 & 9 & 2 & 3 & 0 & 5 & 5 & 5 \\
\hline
\end{tabular}


Table A.2.a(ii). Sacramento simulated cooling and heating annual electricity expenditures $\left[\$ / 1000 \mathrm{ft}^{2}\right]$, the direct savings [\%] from the strategic placement of shade trees and the use of high-albedo roofs, and the indirect savings [\%] from Heat Island Reduction (HIR) strategies for residential buildings. Base electricity expenditure is calculated for buildings without shade trees and with a dark roof (albedo 0.2). Direct savings are determined for buildings with 8 shade trees and a high-albedo roof (albedo 0.5). To estimate direct savings for other changes in albedo $(\Delta \mathrm{a})$ multiply the savings by the ratio $\Delta \mathrm{a} / 0.3$.

\begin{tabular}{|c|c|c|c|c|c|c|c|c|c|c|c|c|}
\hline \multirow{3}{*}{$\begin{array}{c}\text { building azimuth } \\
\& \\
\text { HIR strategy }\end{array}$} & \multicolumn{6}{|c|}{ gas heat } & \multicolumn{6}{|c|}{ electric heat } \\
\hline & \multicolumn{3}{|c|}{-1979} & \multicolumn{3}{|c|}{$1980+$} & \multicolumn{3}{|c|}{-1979} & \multicolumn{3}{|c|}{$1980+$} \\
\hline & R-7 & R-11 & $\mathrm{R}-19$ & $\mathrm{R}-19$ & $R-30$ & $\mathrm{R}-38$ & R-7 & $\mathrm{R}-11$ & R-19 & R-19 & $R-30$ & R-38 \\
\hline \multicolumn{13}{|l|}{$\phi=0$} \\
\hline base expenditure & 172 & 156 & 140 & 77 & 69 & 67 & 681 & 636 & 590 & 235 & 216 & 209 \\
\hline direct shade tree savings & 16 & 17 & 19 & 22 & 22 & 22 & 1 & 1 & 0 & 3 & 3 & 3 \\
\hline direct high albedo savings & 19 & 17 & 16 & 18 & 14 & 15 & 2 & 2 & 1 & 3 & 3 & 3 \\
\hline direct combined savings & 33 & 33 & 32 & 36 & 35 & 36 & 2 & 2 & 1 & 5 & 5 & 5 \\
\hline indirect savings & 9 & 10 & 10 & 10 & 9 & 10 & 1 & 1 & 0 & 2 & 1 & 1 \\
\hline direct $\&$ indirect savings & 40 & 40 & 40 & 43 & 42 & 43 & 3 & 2 & 1 & 6 & 5 & 5 \\
\hline$\phi=90$ & & & & & & & & & & & & \\
\hline base expenditure & 195 & 179 & 164 & 90 & 83 & 81 & 716 & 672 & 627 & 255 & 237 & 229 \\
\hline direct shade tree savings & 21 & 22 & 24 & 27 & 29 & 30 & 2 & 2 & 1 & 5 & 5 & 5 \\
\hline direct high albedo savings & 17 & 16 & 14 & 16 & 13 & 12 & 1 & 1 & 1 & 3 & 3 & 2 \\
\hline direct combined savings & 36 & 36 & 37 & 40 & 40 & 41 & 3 & 2 & 2 & 6 & 7 & 7 \\
\hline indirect savings & 9 & 8 & 9 & 9 & 8 & 10 & 1 & 1 & 0 & 2 & 2 & 1 \\
\hline direct $\&$ indirect savings & 43 & 42 & 43 & 47 & 46 & 47 & 3 & 2 & 1 & 7 & 7 & 7 \\
\hline \multicolumn{13}{|l|}{$\phi=180$} \\
\hline base expenditure & 171 & 155 & 139 & 75 & 68 & 66 & 705 & 660 & 615 & 245 & 226 & 218 \\
\hline direct shade tree savings & 14 & 16 & 17 & 19 & 21 & 21 & 1 & 1 & 0 & 2 & 2 & 2 \\
\hline direct high albedo savings & 19 & 17 & 15 & 17 & 15 & 15 & 1 & 1 & 1 & 2 & 2 & 2 \\
\hline direct combined savings & 32 & 32 & 31 & 33 & 34 & 33 & 2 & 1 & 0 & 4 & 3 & 3 \\
\hline indirect savings & 9 & 9 & 9 & 9 & 10 & 11 & 1 & 0 & 0 & 1 & 1 & 1 \\
\hline direct \& indirect savings & 39 & 39 & 38 & 41 & 41 & 41 & 1 & 0 & 0 & 4 & 3 & 3 \\
\hline \multicolumn{13}{|l|}{$\phi=270$} \\
\hline base expenditure & 188 & 173 & 158 & 86 & 80 & 78 & 706 & 662 & 617 & 250 & 231 & 224 \\
\hline direct shade tree savings & 19 & 21 & 23 & 24 & 26 & 28 & 1 & 1 & 1 & 4 & 4 & 4 \\
\hline direct high albedo savings & 18 & 16 & 14 & 15 & 14 & 14 & 1 & 1 & 1 & 3 & 2 & 2 \\
\hline direct combined savings & 35 & 35 & 35 & 37 & 39 & 38 & 2 & 1 & 1 & 6. & 5 & 5 \\
\hline indirect savings & 8 & 9 & 9 & 8 & 10 & 10 & 1 & 1 & 0 & 2 & 2 & 2 \\
\hline direct $\&$ indirect savings & 41 & 42 & 41 & 44 & 45 & 45 & 2 & 1 & 0 & 6 & 5 & 5 \\
\hline \multicolumn{13}{|l|}{$\phi=\operatorname{avg}$} \\
\hline base expenditure & 182 & 166 & 150 & 82 & 75 & 73 & 702 & 658 & 612 & 246 & 227 & 220 \\
\hline direct shade tree savings & 18 & 19 & 21 & 23 & 20 & 26 & 1 & 1 & 1 & 3 & 4 & 4 \\
\hline direct high albedo savings & 18 & 17 & 15 & 16 & 14 & 14 & 1 & 1 & 1 & 3 & 2 & 2 \\
\hline direct combined savings & 34 & 34 & 34 & 37 & 37 & 37 & 2 & 2 & 1 & 5 & 5 & 5 \\
\hline indirect savings & 9 & 9 & 9 & 9 & 9 & 10 & 1 & 1 & 0 & 2 & 2 & 1 \\
\hline direct $\&$ indirect savings & 41 & 41 & 41 & 44 & 44 & 44 & 2 & 1 & 0 & 5 & 5 & 5 \\
\hline
\end{tabular}


Table A.2.a(iii). Sacramento simulated heating annual natural gas expenditures $\left[\$ / 1000 \mathrm{ft}^{2}\right]$, the direct savings [\%] from the strategic placement of shade trees and the use of high-albedo roofs, and the indirect savings [\%] from Heat Island Reduction (HIR) strategies for residential buildings. Base natural gas expenditure is calculated for buildings without shade trees and with a dark roof (albedo 0.2). Direct savings are determined for buildings with 8 shade trees and a high-albedo roof (albedo 0.5). To estimate direct savings for other changes in albedo $(\Delta \mathrm{a})$ multiply the savings by the ratio $\Delta \mathrm{a} / 0.3$.

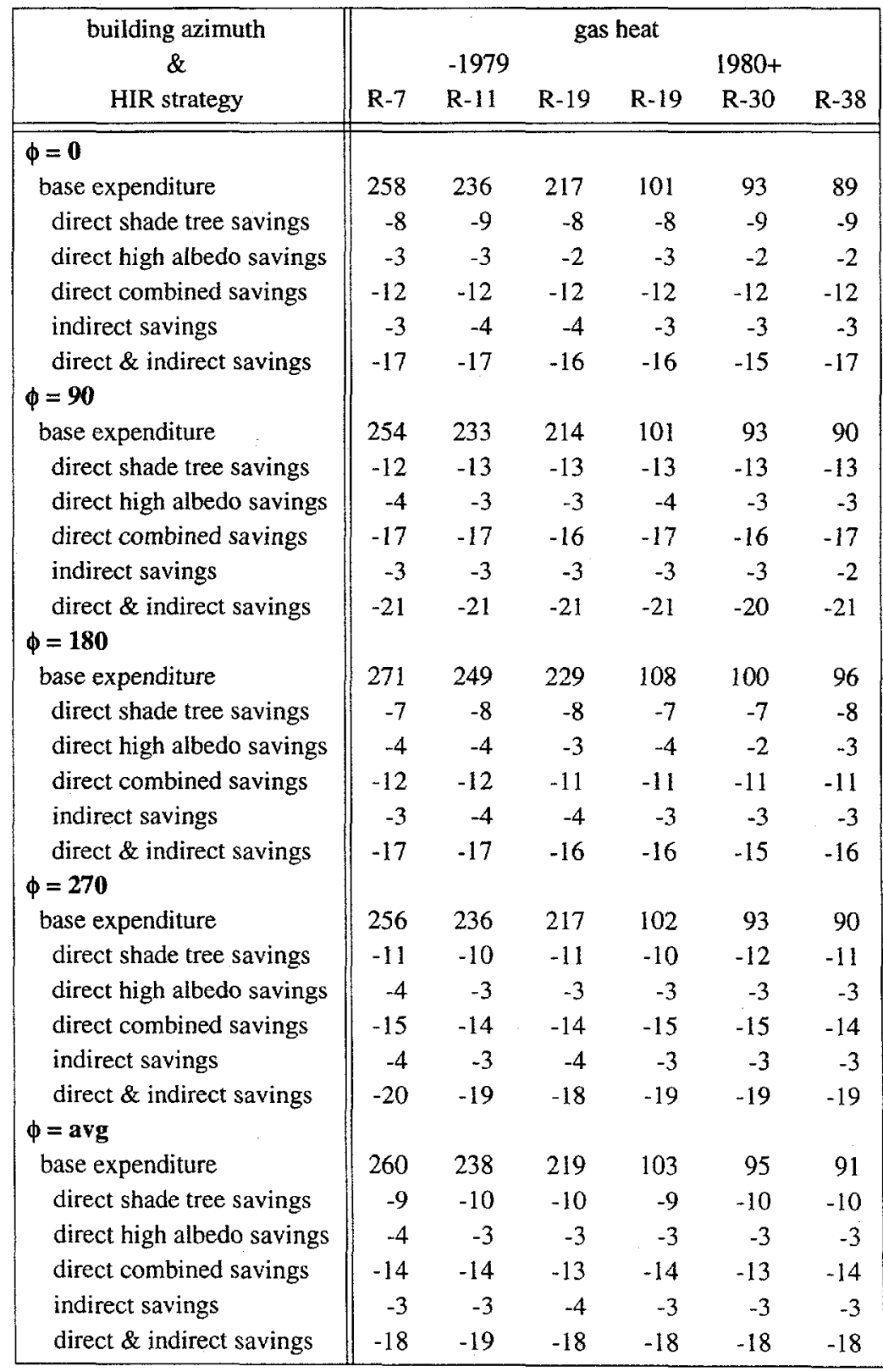


Table A.2.a(iv). Sacramento simulated cooling peak power demand [kW/1000f $\left.\mathrm{t}^{2}\right]$, the direct savings [\%] from the strategic placement of shade trees and the use of high-albedo roofs, and the indirect savings [\%] from Heat Island Reduction (HIR) strategies for residential buildings. Base peak demand is calculated for buildings without shade trees and with a dark roof (albedo 0.2). Direct savings are determined for buildings with 8 shade trees and a high-albedo roof (albedo 0.5). To estimate direct savings for other changes in albedo $(\Delta \mathrm{a})$ multiply the savings by the ratio $\Delta \mathrm{a} / 0.3$.

\begin{tabular}{|c|c|c|c|c|c|c|}
\hline \multirow{3}{*}{$\begin{array}{c}\text { building azimuth } \\
\text { \& } \\
\text { HIR strategy }\end{array}$} & \multicolumn{6}{|c|}{ gas heat } \\
\hline & \multicolumn{3}{|c|}{-1979} & \multicolumn{3}{|c|}{$1980+$} \\
\hline & R-7 & $\mathbf{R}-11$ & R-19 & R-19 & $\mathrm{R}-30$ & R-38 \\
\hline \multicolumn{7}{|l|}{$\phi=0$} \\
\hline base expenditure & 3.54 & 3.50 & 3.49 & 1.92 & 1.91 & 1.91 \\
\hline direct shade tree savings & 9 & 8 & 9 & 10 & 11 & 10 \\
\hline direct high albedo savings & 9 & 7 & 8 & 5 & 6 & 6 \\
\hline direct combined savings & 17 & 17 & 16 & 15 & 15 & 16 \\
\hline indirect savings & 5 & 5 & 5 & 5 & 4 & 5 \\
\hline direct $\&$ indirect savings & 21 & 22 & 21 & 20 & 21 & 22 \\
\hline \multicolumn{7}{|l|}{$\phi=90$} \\
\hline base expenditure & 3.76 & 3.70 & 3.68 & 2.06 & 2.06 & 2.06 \\
\hline direct shade tree savings & 11 & 10 & 12 & 14 & 14 & 14 \\
\hline direct high albedo savings & 9 & 7 & 6 & 4 & 5 & 6 \\
\hline direct combined savings & 19 & 19 & 18 & 19 & 19 & 20 \\
\hline indirect savings & 3 & 4 & 3 & 4 & 4 & 4 \\
\hline direct $\&$ indirect savings & 23 & 23 & 23 & 23 & 24 & 25 \\
\hline \multicolumn{7}{|l|}{$\phi=180$} \\
\hline base expenditure & 3.55 & 3.51 & 3.51 & 1.93 & 1.92 & 1.91 \\
\hline direct shade tree savings & 6 & 6 & 6 & 11 & 11 & 11 \\
\hline direct high albedo savings & 9 & 7 & 8 & 6 & 6 & 6 \\
\hline direct combined savings & 15 & 14 & 14 & 16 & 16 & 16 \\
\hline indirect savings & 5 & 5 & 5 & 5 & 4 & 4 \\
\hline direct \& indirect savings & 20 & 19 & 18 & 21 & 21 & 22 \\
\hline \multicolumn{7}{|l|}{$\phi=\mathbf{2 7 0}$} \\
\hline base expenditure & 3.66 & 3.61 & 3.60 & 1.98 & 1.98 & 1.97 \\
\hline direct shade tree savings & 7 & 6 & 6 & 11 & 12 & 12 \\
\hline direct high albedo savings & 9 & 7 & 8 & 5 & 6 & 6 \\
\hline direct combined savings & 16 & 14 & 14 & 17 & 16 & 17 \\
\hline indirect savings & 5 & 4 & 5 & 4 & 5 & 4 \\
\hline direct \& indirect savings & 21 & 19 & 19 & 21 & 22 & 22 \\
\hline \multicolumn{7}{|l|}{$\phi=$ avg } \\
\hline base expenditure & 3.63 & 3.58 & 3.57 & 1.97 & 1.97 & 1.96 \\
\hline direct shade tree savings & 8 & 7 & 8 & 12 & 9 & 12. \\
\hline direct high albedo savings & 9 & 7 & 8 & 5 & 6 & 6 \\
\hline direct combined savings & 17 & 16 & 15 & 17 & 16 & 17 \\
\hline indirect savings & 4 & 4 & 4 & 4 & 4 & 4 \\
\hline direct \& indirect savings & 21 & 21 & 20 & 22 & 22 & 23 \\
\hline
\end{tabular}


Table A.2.b(i). Sacramento simulated cooling and heating annual total energy expenditures $\left[\$ / 1000 \mathrm{ft}^{2}\right]$, the direct savings [\%] from the strategic placement of shade trees and the use of high-albedo roofs, and the indirect savings [\%] from Heat Island Reduction (HIR) strategies for office buildings. Base energy expenditure is calculated for buildings without shade trees and with a dark roof (albedo 0.2). Direct savings are determined for buildings with 8 shade trees and a high-albedo roof (albedo 0.6). To estimate direct savings for other changes in albedo $(\Delta \mathrm{a})$ multiply the savings by the ratio $\Delta \mathrm{a} / 0.4$.

\begin{tabular}{|c|c|c|c|c|c|c|c|c|c|c|c|c|}
\hline \multirow{3}{*}{$\begin{array}{c}\text { building azimuth } \\
\& \\
\text { HIR strategy }\end{array}$} & \multicolumn{6}{|c|}{ gas heat } & \multicolumn{6}{|c|}{ electric heat } \\
\hline & \multicolumn{3}{|c|}{-1979} & \multicolumn{3}{|c|}{$1980+$} & \multicolumn{3}{|c|}{-1979} & \multicolumn{3}{|c|}{$1980+$} \\
\hline & $R-7$ & R-11 & R-19 & R-19 & R-30 & R-38 & R-7 & R-11 & R-19 & R-19 & R-30 & R-38 \\
\hline \multicolumn{13}{|l|}{$\phi=0$} \\
\hline base expenditure & 1003 & 977 & 952 & 445 & 436 & 432 & 1041 & 1012 & 984 & 449 & 440 & 437 \\
\hline direct shade tree savings & 6 & 6 & 6 & 4 & 4 & 4 & 6 & 5 & 5 & 4 & 4 & 4 \\
\hline direct high albedo savings & 8 & 6 & 5 & 5 & 4 & 3 & 7 & 6 & 4 & 5 & 4 & 3 \\
\hline direct combined savings & 13 & 12 & 10 & 9 & 8 & 7 & 13 & 11 & 10 & 9 & 8 & 7 \\
\hline indirect savings & 3 & 3 & 3 & 4 & 4 & 4 & 3 & 3 & 3 & 4 & 4 & 4 \\
\hline direct \& indirect savings & 16 & 15 & 13 & 13 & 12 & 12 & 16 & 14 & 12 & 13 & 12 & 12 \\
\hline \multicolumn{13}{|l|}{$\phi=90$} \\
\hline base expenditure & 996 & 970 & 946 & 454 & 445 & 441 & 1035 & 1006 & 980 & 460 & 450 & 446 \\
\hline direct shade tree savings & 9 & 9 & 9 & 9 & 10 & 10 & 8 & 9 & 9 & 9 & 10 & 10 \\
\hline direct high albedo savings & 7 & 6 & 4 & 5 & 4 & 3 & 7 & 6 & 4 & 5 & 4 & 3 \\
\hline direct combined savings & 16 & 15 & 14 & 14 & 13 & 13 & 15 & 14 & 13 & 14 & 13 & 13 \\
\hline indirect savings & 4 & 4 & 3 & 4 & 4 & 4 & 4 & 3 & 3 & 4 & 4 & 4 \\
\hline direct \& indirect savings & 19 & 18 & 17 & 18 & 18 & 17 & 19 & 18 & 17 & 18 & 17 & 17 \\
\hline \multicolumn{13}{|l|}{$\phi=$ avg } \\
\hline base expenditure & 1000 & 974 & 949 & 450 & 440 & 436 & 1038 & 1009 & 982 & 454 & 445 & 442 \\
\hline direct shade tree savings & 7 & 7 & 7 & 7 & 7 & 7 & 7 & 7 & 7 & 7 & 7 & 7 \\
\hline direct high albedo savings & 8 & 6 & 4 & 5 & 4 & 3 & 7 & 6 & 4 & 5 & 4 & 3 \\
\hline direct combined savings & 15 & 13 & 12 & 12 & 11 & 10 & 14 & 13 & 11 & 12 & 11 & 10 \\
\hline indirect savings & 4 & 3 & 3 & 4 & 4 & 4 & 4 & 3 & 3 & 4 & 4 & 4 \\
\hline direct \& indirect savings & 18 & 16 & 15 & 16 & 15 & 14 & 17 & 16 & 15 & 15 & 14 & 14 \\
\hline
\end{tabular}


Table A.2.b(ii). Sacramento simulated cooling and heating annual electricity expenditures $\left[\$ / 1000 \mathrm{ft}^{2}\right]$, the direct savings [\%] from the strategic placement of shade trees and the use of high-albedo roofs, and the indirect savings [\%] from Heat Island Reduction (HIR) strategies for office buildings. Base electricity expenditure is calculated for buildings without shade trees and with a dark roof (albedo 0.2). Direct savings are determined for buildings with 8 shade trees and a high-albedo roof (albedo 0.6). To estimate direct savings for other changes in albedo $(\Delta \mathrm{a})$ multiply the savings by the ratio $\Delta \mathrm{a} / 0.4$.

\begin{tabular}{|c|c|c|c|c|c|c|c|c|c|c|c|c|}
\hline \multirow{3}{*}{$\begin{array}{c}\text { building azimuth } \\
\qquad \& \\
\text { HIR strategy }\end{array}$} & \multicolumn{6}{|c|}{ gas heat } & \multicolumn{6}{|c|}{ electric heat } \\
\hline & \multicolumn{3}{|c|}{-1979} & \multicolumn{3}{|c|}{$1980+$} & \multicolumn{3}{|c|}{-1979} & \multicolumn{3}{|c|}{$1980+$} \\
\hline & $\mathrm{R}-7$ & R-11 & R-19 & R-19 & $\mathrm{R}-30$ & $\mathrm{R}-38$ & $\mathrm{R}-7$ & R-11 & $\mathrm{R}-19$ & R-19 & $\mathrm{R}-30$ & $\mathrm{R}-38$ \\
\hline \multicolumn{13}{|l|}{$\phi=0$} \\
\hline base expenditure & 895 & 878 & 862 & 423 & 416 & 414 & 1041 & 1012 & 984 & 449 & 440 & 437 \\
\hline direct shade tree savings & 6 & 6 & 6 & 5 & 5 & 5 & 6 & 5 & 5 & 4 & 4 & 4 \\
\hline direct high albedo savings & 9 & 7 & 5 & 6 & 4 & 4 & 7 & 6 & 4 & 5 & 4 & 3 \\
\hline direct combined savings & 15 & 13 & 11 & 10 & 9 & 8 & 13 & 11 & 10 & 9 & 8 & 7 \\
\hline indirect savings & 4 & 4 & 4 & 5 & 5 & 5 & 3 & 3 & 3 & 4 & 4 & 4 \\
\hline direct $\&$ indirect savings & 19 & 17 & 15 & 15 & 13 & 13 & 16 & 14 & 12 & 13 & 12 & 12 \\
\hline$\phi=90$ & & & & & & & & & & & & \\
\hline base expenditure & 886 & 870 & 855 & 430 & 423 & 421 & 1035 & 1006 & 980 & 460 & 450 & 446 \\
\hline direct shade tree savings & 10 & 10 & 10 & 10 & 10 & 10 & 8 & 9 & 9 & 9 & 10 & 10 \\
\hline direct high albedo savings & 9 & 7 & 5 & 6 & 4 & 4 & 7 & 6 & 4 & 5 & 4 & 3 \\
\hline direct combined savings & 19 & 17 & 16 & 16 & 15 & 14 & 15 & 14 & 13 & 14 & 13 & 13 \\
\hline indirect savings & 4 & 4 & 4 & 5 & 4 & 5 & 4 & 3 & 3 & 4 & 4 & 4 \\
\hline direct $\&$ indirect savings & 23 & 21 & 19 & 20 & 19 & 19 & 19 & 18 & 17 & 18 & 17 & 17 \\
\hline$\phi=\operatorname{avg}$ & & & & & & & & & & & & \\
\hline base expenditure & 891 & 874 & 858 & 426 & 420 & 418 & 1038 & 1009 & 982 & 454 & 445 & 442 \\
\hline direct shade tree savings & 8 & 8 & 8 & 8 & 7 & 8 & 7 & 7 & 7 & 7 & 7 & 7 \\
\hline direct high albedo savings & 9 & 7 & 5 & 6 & 4 & 4 & 7 & 6 & 4 & 5 & 4 & 3 \\
\hline direct combined savings & 17 & 15 & 14 & 13 & 12 & 11 & 14 & 13 & 11 & 12 & 11 & 10 \\
\hline indirect savings & 4 & 4 & 4 & 5 & 5 & 5 & 4 & 3 & 3 & 4 & 4 & 4 \\
\hline direct $\&$ indirect savings & 21 & 19 & 17 & 17 & 16 & 16 & 17 & 16 & 15 & 15 & 14 & 14 \\
\hline
\end{tabular}


Table A.2.b(iii). Sacramento simulated heating annual natural gas expenditures $\left[\$ / 1000 \mathrm{ft}^{2}\right]$, the direct savings [\%] from the strategic placement of shade trees and the use of high-albedo roofs, and the indirect savings [\%] from Heat Island Reduction (HIR) strategies for office buildings. Base natural gas expenditure is calculated for buildings without shade trees and with a dark roof (albedo 0.2). Direct savings are determined for buildings with 8 shade trees and a high-albedo roof (albedo 0.6). To estimate direct savings for other changes in albedo $(\Delta \mathrm{a})$ multiply the savings by the ratio $\Delta \mathrm{a} / 0.4$.

\begin{tabular}{|l||rrrrrr|}
\hline \multicolumn{1}{|c||}{$\begin{array}{c}\text { building azimuth } \\
\text { \& } \\
\text { HIR strategy }\end{array}$} & \multicolumn{5}{c|}{ gas heat } \\
R-7 & $\begin{array}{r}\text { R-11 } \\
\phi=0\end{array}$ & R-19 & R-19 & R-30 & R-38 \\
\hline base expenditure & 108 & 99 & 90 & 22 & 19 & 18 \\
direct shade tree savings & 0 & 0 & 0 & 0 & -5 & -6 \\
direct high albedo savings & -6 & -4 & -3 & -9 & -11 & -11 \\
direct combined savings & -6 & -4 & -3 & -9 & -16 & -17 \\
indirect savings & 0 & 0 & -1 & 0 & -5 & -6 \\
direct \& indirect savings & -6 & -5 & -4 & -14 & -16 & -17 \\
$\phi=90$ & & & & & & \\
base expenditure & 110 & 101 & 92 & 24 & 21 & 21 \\
direct shade tree savings & -1 & 0 & 0 & 0 & -5 & 0 \\
direct high albedo savings & -5 & -4 & -3 & -8 & -10 & -5 \\
direct combined savings & -6 & -5 & -4 & -12 & -14 & -5 \\
indirect savings & 0 & 0 & 0 & 0 & -5 & 0 \\
direct \& indirect savings & -7 & -6 & -4 & -12 & -14 & -10 \\
$\phi=$ avg & & & & & & \\
base expenditure & 109 & 100 & 91 & 23 & 20 & 20 \\
direct shade tree savings & 0 & -1 & 0 & 0 & 0 & -3 \\
direct high albedo savings & -6 & -5 & -3 & -9 & -5 & -8 \\
direct combined savings & -6 & -5 & -4 & -11 & -10 & -10 \\
indirect savings & 0 & -1 & -1 & 0 & 0 & -3 \\
direct \& indirect savings & -7 & -6 & -4 & -13 & -10 & -13 \\
\hline
\end{tabular}


Table A.2.b(iv). Sacramento simulated cooling peak power demand [kW/1000f $\left.\mathrm{f}^{2}\right]$, the direct savings [\%] from the strategic placement of shade trees and the use of high-albedo roofs, and the indirect savings [\%] from Heat Island Reduction (HIR) strategies for office buildings. Base peak demand is calculated for buildings without shade trees and with a dark roof (albedo 0.2). Direct savings are determined for buildings with 8 shade trees and a high-albedo roof (albedo 0.6). To estimate direct savings for other changes in albedo $(\Delta \mathrm{a})$ multiply the savings by the ratio $\Delta \mathrm{a} / 0.4$.

\begin{tabular}{|l||cccccc|}
\hline \multicolumn{1}{|c|}{$\begin{array}{c}\text { building azimuth } \\
\text { \& }\end{array}$} & \multicolumn{5}{c|}{ gas heat } \\
\multicolumn{1}{|c}{ HIR strategy } & R-7 & R-11 & R-19 & R-19 & R-30 & R-38 \\
\hline \hline $\begin{array}{l}\phi=0 \\
\text { base expenditure }\end{array}$ & 8.01 & 7.73 & 7.45 & 4.22 & 4.11 & 4.06 \\
direct shade tree savings & 3 & 3 & 2 & 0 & 0 & 0 \\
direct high albedo savings & 7 & 5 & 4 & 5 & 4 & 3 \\
direct combined savings & 10 & 8 & 7 & 5 & 3 & 3 \\
indirect savings & 4 & 5 & 4 & 4 & 4 & 4 \\
direct \& indirect savings & 14 & 12 & 11 & 9 & 8 & 7 \\
$\phi=90$ & & & & & & \\
base expenditure & 8.22 & 7.95 & 7.70 & 4.44 & 4.34 & 4.29 \\
direct shade tree savings & 7 & 7 & 8 & 8 & 8 & 8 \\
direct high albedo savings & 6 & 5 & 4 & 4 & 3 & 3 \\
direct combined savings & 14 & 13 & 12 & 12 & 11 & 11 \\
indirect savings & 4 & 4 & 4 & 4 & 4 & 4 \\
direct \& indirect savings & 18 & 17 & 16 & 16 & 15 & 15 \\
$\phi=$ avg & & & & & & \\
base expenditure & 8.11 & 7.84 & 7.58 & 4.33 & 4.22 & 4.18 \\
direct shade tree savings & 5 & 5 & 5 & 4 & 4 & 4 \\
direct high albedo savings & 7 & 5 & 4 & 5 & 3 & 3 \\
direct combined savings & 12 & 11 & 9 & 9 & 7 & 7 \\
indirect savings & 4 & 4 & 4 & 4 & 4 & 4 \\
direct \& indirect savings & 16 & 15 & 13 & 12 & 11 & 11 \\
\hline
\end{tabular}


Table A.2.c(i). Sacramento simulated cooling and heating annual total energy expenditures $\left[\$ / 1000 \mathrm{ft}^{2}\right]$, the direct savings [\%] from the strategic placement of shade trees and the use of high-albedo roofs, and the indirect savings [\%] from Heat Island Reduction (HIR) strategies for retail buildings. Base energy expenditure is calculated for buildings without shade trees and with a dark roof (albedo 0.2). Direct savings are determined for buildings with 4 shade trees and a high-albedo roof (albedo 0.6). To estimate direct savings for other changes in albedo $(\Delta \mathrm{a})$ multiply the savings by the ratio $\Delta \mathrm{a} / 0.4$.

\begin{tabular}{|c|c|c|c|c|c|c|c|c|c|c|c|c|}
\hline \multirow{3}{*}{$\begin{array}{c}\text { building azimuth } \\
\& \\
\text { HIR strategy } \\
\end{array}$} & \multicolumn{6}{|c|}{ gas heat } & \multicolumn{6}{|c|}{ electric heat } \\
\hline & \multicolumn{3}{|c|}{-1979} & \multicolumn{3}{|c|}{$1980+$} & \multicolumn{3}{|c|}{-1979} & \multicolumn{3}{|c|}{$1980+$} \\
\hline & $\mathrm{R}-7$ & $\mathrm{R}-11$ & R-19 & R-19 & R-30 & R-38 & R-7 & $\mathrm{R}-11$ & R-19 & R-19 & R-30 & R-38 \\
\hline \multicolumn{13}{|l|}{$\phi=0$} \\
\hline base expenditure & 1071 & 1053 & 1037 & 414 & 408 & 406 & 1079 & 1059 & 1041 & 415 & 408 & 406 \\
\hline direct shade tree savings & 6 & 6 & 6 & 6 & 6 & 6 & 6 & 6 & 6 & 6 & 6 & 6 \\
\hline direct high albedo savings & 10 & 8 & 6 & 8 & 6 & 6 & 10 & 8 & 6 & 8 & 6 & 6 \\
\hline direct combined savings & 15 & 14 & 12 & 14 & 12 & 11 & 15 & 14 & 12 & 14 & 12 & 11 \\
\hline indirect savings & 2 & 2 & 2 & 4 & 4 & 4 & 2 & 2 & 2 & 4 & 4 & 4 \\
\hline direct \& indirect savings & 18 & 16 & 14 & 17 & 15 & 15 & 17 & 16 & 14 & 18 & 15 & 15 \\
\hline \multicolumn{13}{|l|}{$\phi=90$} \\
\hline base expenditure & 1073 & 1047 & 1027 & 424 & 416 & 412 & 1084 & 1054 & 1033 & 424 & 416 & 413 \\
\hline direct shade tree savings & 7 & 8 & 9 & 10 & 11 & 11 & 7 & 8 & 9 & 10 & 11 & 11 \\
\hline direct high albedo savings & 11 & 8 & 6 & 8 & 6 & 6 & 11 & 8 & 6 & 8 & 6 & 6 \\
\hline direct combined savings & 19 & 18 & 16 & 19 & 18 & 17 & 18 & 17 & 16 & 19 & 18 & 17 \\
\hline indirect savings & 3 & 2 & 2 & 4 & 4 & 4 & 3 & 2 & 2 & 4 & 4 & 4 \\
\hline direct $\&$ indirect savings & 21 & 20 & 19 & 23 & 21 & 20 & 21 & 19 & 18 & 23 & 21 & 21 \\
\hline \multicolumn{13}{|l|}{$\phi=270$} \\
\hline base expenditure & 1039 & 1007 & 978 & 405 & 395 & 391 & 1050 & 1015 & 983 & 405 & 395 & 391 \\
\hline direct shade tree savings & 7 & 7 & 7 & 9 & 9 & 9 & 7 & 7 & 7 & 9 & 9 & 9 \\
\hline direct high albedo savings & 12 & 10 & 7 & 9 & 7 & 6 & 12 & 10 & 7 & 9 & 7 & 6 \\
\hline direct combined savings & 18 & 16 & 15 & 18 & 16 & 15 & 18 & 16 & 15 & 18 & 16 & 15 \\
\hline indirect savings & 3 & 3 & 3 & 4 & 4 & 4 & 3 & 3 & 3 & 4 & 4 & 4 \\
\hline direct \& indirect savings & 21 & 19 & 17 & 21 & 19 & 19 & 21 & 19 & 17 & 21 & 19 & 19 \\
\hline \multicolumn{13}{|l|}{$\phi=$ avg } \\
\hline base expenditure & 1061 & 1036 & 1014 & 414 & 406 & 403 & 1071 & 1043 & 1019 & 415 & 406 & 403 \\
\hline direct shade tree savings & 6 & 7 & 7 & 8 & 9 & 9 & 7 & 7 & 7 & 8 & 9 & 9 \\
\hline direct high albedo savings & 11 & 9 & 7 & 8 & 7 & 6 & 11 & 9 & 7 & 8 & 6 & 6 \\
\hline direct combined savings & 17 & 16 & 14 & 17 & 15 & 14 & 17 & 16 & 14 & 17 & 15 & 15 \\
\hline indirect savings & 3 & 2 & 2 & 4 & 4 & 4 & 3 & 2 & 2 & 4 & 4 & 4 \\
\hline direct \& indirect savings & 20 & 18 & 17 & 21 & 19 & 18 & 20 & 18 & 17 & 21 & 19 & 18 \\
\hline
\end{tabular}


Table A.2.c(ii). Sacramento simulated cooling and heating annual electricity expenditures $\left[\$ / 1000 \mathrm{ft}^{2}\right]$, the direct savings [\%] from the strategic placement of shade trees and the use of high-albedo roofs, and the indirect savings [\%] from Heat Island Reduction (HIR) strategies for retail buildings. Base electricity expenditure is calculated for buildings without shade trees and with a dark roof (albedo 0.2). Direct savings are determined for buildings with 4 shade trees and a high-albedo roof (albedo 0.6). To estimate direct savings for other changes in albedo $(\Delta \mathrm{a})$ multiply the savings by the ratio $\Delta \mathrm{a} / 0.4$.

\begin{tabular}{|c|c|c|c|c|c|c|c|c|c|c|c|c|}
\hline \multirow{3}{*}{$\begin{array}{c}\text { building azimuth } \\
\qquad \& \\
\text { HIR strategy } \\
\end{array}$} & \multicolumn{6}{|c|}{ gas heat } & \multicolumn{6}{|c|}{ electric heat } \\
\hline & \multicolumn{3}{|c|}{-1979} & \multicolumn{3}{|c|}{$1980+$} & \multicolumn{3}{|c|}{-1979} & \multicolumn{3}{|c|}{$1980+$} \\
\hline & R-7 & $\mathrm{R}-11$ & R-19 & $\mathrm{R}-19$ & $\mathrm{R}-30$ & R-38 & $\mathrm{R}-7$ & $\mathrm{R}-11$ & $\mathrm{R}-19$ & R-19 & $\mathrm{R}-30$ & R-38 \\
\hline \multicolumn{13}{|l|}{$\phi=0$} \\
\hline base expenditure & 1049 & 1038 & 1026 & 414 & 408 & 406 & 1079 & 1059 & 1041 & 415 & 408 & 406 \\
\hline direct shade tree savings & 6 & 6 & 6 & 6 & 6 & 6 & 6 & 6 & 6 & 6 & 6 & 6 \\
\hline direct high albedo savings & 10 & 8 & 6 & 8 & 6 & 6 & 10 & 8 & 6 & 8 & 6 & 6 \\
\hline direct combined savings & 16 & 14 & 12 & 14 & 12 & 11 & 15 & 14 & 12 & 14 & 12 & 11 \\
\hline indirect savings & 2 & 2 & 2 & 4 & 4 & 4 & 2 & 2 & 2 & 4 & 4 & 4 \\
\hline direct $\&$ indirect savings & 18 & 16 & 14 & 18 & 16 & 15 & 17 & 16 & 14 & 18 & 15 & 15 \\
\hline$\phi=90$ & & & & & & & & & & & & \\
\hline base expenditure & 1045 & 1027 & 1013 & 423 & 415 & 412 & 1084 & 1054 & 1033 & 424 & 416 & 413 \\
\hline direct shade tree savings & 7 & 8 & 9 & 10 & 11 & 11 & 7 & 8 & 9 & 10 & 11 & 11 \\
\hline direct high albedo savings & 11 & 9 & 7 & 8 & 7 & 6 & 11 & 8 & 6 & 8 & 6 & 6 \\
\hline direct combined savings & 19 & 18 & 16 & 19 & 18 & 17 & 18 & 17 & 16 & 19 & 18 & 17 \\
\hline indirect savings & 3 & 2 & 2 & 4 & 4 & 4 & 3 & 2 & 2 & 4 & 4 & 4 \\
\hline direct \& indirect savings & 22 & 20 & 19 & 23 & 21 & 20 & 21 & 19 & 18 & 23 & 21 & 21 \\
\hline \multicolumn{13}{|l|}{$\phi=\mathbf{2 7 0}$} \\
\hline base expenditure & 1011 & 988 & 965 & 404 & 395 & 391 & 1050 & 1015 & 983 & 405 & 395 & 391 \\
\hline direct shade tree savings & 7 & 7 & 7 & 9 & 9 & 9 & 7 & 7 & 7 & 9 & 9 & 9 \\
\hline direct high albedo savings & 12 & 10 & 8 & 9 & 7 & 6 & 12 & 10 & 7 & 9 & 7 & 6 \\
\hline direct combined savings & 19 & 17 & 15 & 18 & 16 & 15 & 18 & 16 & 15 & 18 & 16 & 15 \\
\hline indirect savings & 3 & 3 & 3 & 4 & 4 & 4 & 3 & 3 & 3 & 4 & 4 & 4 \\
\hline direct \& indirect savings & 22 & 20 & 18 & 21 & 19 & 19 & 21 & 19 & 17 & 21 & 19 & 19 \\
\hline \multicolumn{13}{|l|}{$\phi=\operatorname{avg}$} \\
\hline base expenditure & 1035 & 1018 & 1001 & 414 & 406 & 403 & 1071 & 1043 & 1019 & 415 & 406 & 403 \\
\hline direct shade tree savings & 7 & 7 & 7 & 8 & 9 & 9 & 7 & 7 & 7 & 8 & 9 & 9 \\
\hline direct high albedo savings & 11 & 9 & 7 & 8 & 7 & 6 & 11 & 9 & 7 & 8 & 6 & 6 \\
\hline direct combined savings & 18 & 16 & 14 & 17 & 15 & 14 & 17 & 16 & 14 & 17 & 15 & 15 \\
\hline indirect savings & 3 & 3 & 2 & 4 & 4 & 4 & 3 & 2 & 2 & 4 & 4 & 4 \\
\hline direct \& indirect savings & 21 & 19 & 17 & 21 & 19 & 18 & 20 & 18 & 17 & 21 & 19 & 18 \\
\hline
\end{tabular}


Table A.2.c(iii). Sacramento simulated heating annual natural gas expenditures $\left[\$ / 1000 \mathrm{ft}^{2}\right]$, the direct savings [\%] from the strategic placement of shade trees and the use of high-albedo roofs, and the indirect savings [\%] from Heat Island Reduction (HIR) strategies for retail buildings. Base natural gas expenditure is calculated for buildings without shade trees and with a dark roof (albedo 0.2). Direct savings are determined for buildings with 4 shade trees and a high-albedo roof (albedo 0.6). To estimate direct savings for other changes in albedo $(\Delta \mathrm{a})$ multiply the savings by the ratio $\Delta \mathrm{a} / 0.4$.

\begin{tabular}{|l||rrrrrr|}
\hline \multicolumn{1}{|c|}{$\begin{array}{c}\text { building azimuth } \\
\text { HIR strategy }\end{array}$} & \multicolumn{7}{c}{ gas heat } \\
R-7 & R-11 & R-19 & R-19 & R-30 & R-38 \\
\hline \hline $\boldsymbol{\phi}=\mathbf{0}$ & 22 & 16 & 11 & 1 & 0 & 0 \\
base expenditure & 0 & 0 & 9 & 100 & 0 & 0 \\
direct shade tree savings & -9 & -6 & 0 & 0 & 0 & 0 \\
direct high albedo savings & -9 & -6 & 9 & 100 & 0 & 0 \\
direct combined savings & -9 & -6 & 0 & 0 & 0 & 0 \\
indirect savings & 0 & 0 & 0 & 100 & 0 & 0 \\
direct \& indirect savings & -14 & 0 & 0 & & & \\
$\phi=90$ & & & & & 1 & 1 \\
base expenditure & 28 & 20 & 14 & 1 & 1 & 100 \\
direct shade tree savings & 0 & 5 & 7 & 0 & 100 & 100 \\
direct high albedo savings & -11 & -10 & 0 & 0 & 0 & 100 \\
direct combined savings & -11 & -5 & 0 & 100 & 100 & 100 \\
indirect savings & -4 & 0 & 0 & 0 & 0 & 100 \\
direct \& indirect savings & -14 & -5 & 0 & 100 & 100 & 100 \\
$\phi=270$ & & & & & & \\
base expenditure & 28 & 19 & 13 & 0 & 0 & 0 \\
direct shade tree savings & 0 & 0 & 0 & 0 & 0 & 0 \\
direct high albedo savings & -7 & -5 & 0 & 0 & 0 & 0 \\
direct combined savings & -7 & -11 & 0 & 0 & 0 & 0 \\
indirect savings & 0 & 0 & 0 & 0 & 0 & 0 \\
direct \& indirect savings & -11 & -11 & 0 & 0 & 0 & 0 \\
$\phi=$ avg & & & & & & \\
base expenditure & 26 & 18 & 13 & 1 & 0 & 0 \\
direct shade tree savings & 0 & 0 & 5 & 50 & 0 & 100 \\
direct high albedo savings & -9 & -11 & 0 & 0 & 0 & 100 \\
direct combined savings & -9 & -11 & 3 & 100 & 0 & 100 \\
indirect savings & -1 & 0 & 0 & 0 & 0 & 100 \\
direct \& indirect savings & -13 & -11 & 0 & 100 & 0 & 100 \\
\hline
\end{tabular}


Table A.2.c(iv). Sacramento simulated cooling peak power demand $\left[\mathrm{kW} / 1000 \mathrm{ft}^{2}\right]$, the direct savings [\%] from the strategic placement of shade trees and the use of high-albedo roofs, and the indirect savings [\%] from Heat Island Reduction (HIR) strategies for retail buildings. Base peak demand is calculated for buildings without shade trees and with a dark roof (albedo 0.2). Direct savings are determined for buildings with 4 shade trees and a high-albedo roof (albedo 0.6 ). To estimate direct savings for other changes in albedo $(\Delta \mathrm{a})$ multiply the savings by the ratio $\Delta \mathrm{a} / 0.4$.

\begin{tabular}{|l||cccccc|}
\hline \multicolumn{1}{|c|}{$\begin{array}{c}\text { building azimuth } \\
\text { \& }\end{array}$} & \multicolumn{5}{c|}{ gas heat } \\
\multicolumn{1}{|c}{ HIR strategy } & $\mathrm{R}-7$ & $\mathrm{R}-11$ & $\mathrm{R}-19$ & $\mathrm{R}-19$ & $\mathrm{R}-30$ & $\mathrm{R}-38$ \\
\hline \hline $\boldsymbol{\phi} \mathbf{0}$ & & & & & & \\
base expenditure & 5.99 & 5.78 & 5.56 & 3.02 & 2.93 & 2.89 \\
direct shade tree savings & 6 & 7 & 7 & 7 & 7 & 7 \\
direct high albedo savings & 7 & 6 & 5 & 7 & 6 & 6 \\
direct combined savings & 13 & 12 & 11 & 12 & 11 & 11 \\
indirect savings & 3 & 3 & 3 & 3 & 3 & 3 \\
direct \& indirect savings & 16 & 15 & 14 & 15 & 14 & 13 \\
$\phi=90$ & & & & & & \\
base expenditure & 6.55 & 5.97 & 5.74 & 3.19 & 3.09 & 3.05 \\
direct shade tree savings & 7 & 3 & 5 & 7 & 8 & 9 \\
direct high albedo savings & 13 & 7 & 5 & 7 & 5 & 5 \\
direct combined savings & 17 & 17 & 17 & 20 & 19 & 19 \\
indirect savings & 8 & 3 & 3 & 3 & 3 & 3 \\
direct \& indirect savings & 20 & 16 & 20 & 23 & 22 & 22 \\
$\phi=270$ & & & & & & \\
base expenditure & 6.21 & 5.87 & 5.54 & 3.01 & 2.87 & 2.82 \\
direct shade tree savings & 5 & 6 & 6 & 6 & 6 & 6 \\
direct high albedo savings & 11 & 9 & 7 & 8 & 7 & 6 \\
direct combined savings & 16 & 15 & 19 & 20 & 18 & 17 \\
indirect savings & 4 & 4 & 4 & 4 & 4 & 4 \\
direct \& indirect savings & 20 & 18 & 22 & 23 & 21 & 21 \\
$\phi=$ avg & & & & & \\
base expenditure & 6.25 & 5.87 & 5.62 & 3.07 & 2.96 & 2.92 \\
direct shade tree savings & 6 & 5 & 6 & 6 & 7 & 7 \\
direct high albedo savings & 10 & 7 & 6 & 7 & 6 & 6 \\
direct combined savings & 16 & 13 & 16 & 17 & 16 & 16 \\
indirect savings & 5 & 3 & 3 & 3 & 3 & 3 \\
direct \& indirect savings & 19 & 16 & 19 & 20 & 19 & 19 \\
\hline
\end{tabular}


Table A.3.a(i). Salt Lake City simulated cooling and heating annual total energy expenditures $\left[\$ / 1000 \mathrm{ft}^{2}\right]$, the direct savings [\%] from the strategic placement of shade trees and the use of high-albedo roofs, and the indirect savings [\%] from Heat Island Reduction (HIR) strategies for residential buildings. Base energy expenditure is calculated for buildings without shade trees and with a dark roof (albedo 0.2). Direct savings are determined for buildings with 8 shade trees and a high-albedo roof (albedo 0.5 ). To estimate direct savings for other changes in albedo $(\Delta \mathrm{a})$ multiply the savings by the ratio $\Delta \mathrm{a} / 0.3$.

\begin{tabular}{|c|c|c|c|c|c|c|c|c|c|c|c|c|}
\hline \multirow{3}{*}{$\begin{array}{c}\text { building azimuth } \\
\qquad \& \\
\text { HIR strategy }\end{array}$} & \multicolumn{6}{|c|}{ gas heat } & \multicolumn{6}{|c|}{ electric heat } \\
\hline & \multicolumn{3}{|c|}{-1979} & \multicolumn{3}{|c|}{$1980+$} & \multicolumn{3}{|c|}{-1979} & \multicolumn{3}{|c|}{$1980+$} \\
\hline & $\mathrm{R}-7$ & $\mathrm{R}-11$ & $\mathrm{R}-19$ & R-19 & R-30 & $\mathrm{R}-38$ & $\mathrm{R}-7$ & $\mathrm{R}-11$ & $\mathrm{R}-19$ & R-19 & $\mathrm{R}-30$ & $\mathrm{R}-38$ \\
\hline \multicolumn{13}{|l|}{$\phi=0$} \\
\hline base expenditure & 636 & 597 & 560 & 276 & 260 & 253 & 1015 & 1002 & 985 & 444 & 427 & 420 \\
\hline direct shade tree savings & 0 & -1 & -1 & 0 & 0 & 0 & 2 & 2 & 2 & 2 & 1 & 1 \\
\hline direct high albedo savings & 2 & 2 & 1 & 1 & 2 & 2 & 0 & 0 & -1 & 0 & 0 & 0 \\
\hline direct combined savings & 0 & 0 & 0 & 1 & 1 & 1 & 1 & 1 & 1 & 1 & 1 & 1 \\
\hline indirect savings & 0 & -1 & -1 & 0 & 0 & 0 & 2 & 2 & 2 & 1 & 1 & 1 \\
\hline direct $\&$ indirect savings & 1 & 1 & 0 & 0 & 0 & 0 & 1 & 1 & 1 & 2 & 1 & 1 \\
\hline \multicolumn{13}{|l|}{$\phi=90$} \\
\hline base expenditure & 644 & 606 & 570 & 288 & 272 & 265 & 1086 & 1070 & 1050 & 478 & 460 & 453 \\
\hline direct shade tree savings & -2 & -2 & -2 & 0 & 0 & 0 & 6 & 5 & 5 & 4 & 4 & 4 \\
\hline direct high albedo savings & 2 & 1 & 1 & 2 & 2 & 2 & 0 & -1 & -1 & 0 & 0 & 0 \\
\hline direct combined savings & -1 & -1 & -2 & 1 & 1 & 1 & 5 & 5 & 4 & 4 & 3 & 3 \\
\hline indirect savings & 0 & 0 & 0 & 1 & 1 & 1 & 1 & 1 & 1 & 0 & 0 & 0 \\
\hline direct \& indirect savings & -2 & -2 & -3 & 0 & 0 & 0 & 6 & 6 & 5 & 3 & 4 & 4 \\
\hline \multicolumn{13}{|l|}{$\phi=180$} \\
\hline base expenditure & 655 & 617 & 579 & 288 & 272 & 265 & 1033 & 1022 & 1007 & 461 & 444 & 437 \\
\hline direct shade tree savings & -1 & -1 & -1 & 0 & 0 & 0 & 2 & 2 & 2 & 2 & 1 & 1 \\
\hline direct high albedo savings & 1 & 1 & 1 & 1 & 1 & 1 & 0 & -1 & -1 & 0 & -1 & -1 \\
\hline direct combined savings & 0 & 0 & 0 & 1 & 1 & 1 & 1 & 1 & 1 & 2 & 1 & 0 \\
\hline indirect savings & 0 & -1 & -1 & 0 & 0 & 0 & 3 & 2 & 2 & 1 & 1 & 1 \\
\hline direct $\&$ indirect savings & 1 & 0 & -1 & 0 & 0 & 0 & 2 & 2 & 1 & 2 & 2 & 1 \\
\hline \multicolumn{13}{|l|}{$\phi=270$} \\
\hline base expenditure & 658 & 620 & 584 & 292 & 276 & 270 & 1050 & 1038 & 1022 & 469 & 453 & 447 \\
\hline direct shade tree savings & 0 & -1 & -1 & 1 & 1 & 1 & 3 & 3 & 3 & 3 & 3 & 3 \\
\hline direct high albedo savings & 1 & 1 & 1 & 1 & 1 & 1 & 0 & 0 & -1 & 0 & 0 & 0 \\
\hline direct combined savings & 0 & 0 & 0 & 2 & 2 & 2 & 3 & 2 & 2 & 2 & 2 & 2 \\
\hline indirect savings & 0 & 0 & 0 & 1 & 1 & 1 & 2 & 2 & 1 & 1 & 1 & 1 \\
\hline direct \& indirect savings & 1 & 0 & 0 & 1 & 1 & 1 & 3 & 3 & 2 & 4 & 3 & 3 \\
\hline \multicolumn{13}{|l|}{$\phi=$ avg } \\
\hline base expenditure & 648 & 610 & 573 & 286 & 270 & 263 & 1046 & 1033 & 1016 & 463 & 446 & 439 \\
\hline direct shade tree savings & -1 & -1 & -1 & 0 & 0 & 0 & 3 & 3 & 3 & 3 & 2 & 2 \\
\hline direct high albedo savings & 1 & 1 & 1 & 1 & 1 & 1 & 0 & -1 & -1 & 0 & 0 & 0 \\
\hline direct combined savings & 0 & 0 & -1 & 1 & 1 & 1 & 3 & 2 & 2 & 2 & 2 & 2 \\
\hline indirect savings & 0 & 0 & 0 & 0 & 1 & 0 & 2 & 2 & 2 & 1 & 1 & 1 \\
\hline direct \& indirect savings & 0 & 0 & -1 & 0 & 1 & 0 & 3 & 3 & 2 & 3 & 3 & 2 \\
\hline
\end{tabular}


Table A.3.a(ii). Salt Lake City simulated cooling and heating annual electricity expenditures $\left[\$ / 1000 \mathrm{ft}^{2}\right]$, the direct savings [\%] from the strategic placement of shade trees and the use of high-albedo roofs, and the indirect savings [\%] from Heat Island Reduction (HIR) strategies for residential buildings. Base electricity expenditure is calculated for buildings without shade trees and with a dark roof (albedo 0.2). Direct savings are determined for buildings with 8 shade trees and a high-albedo roof (albedo 0.5$)$. To estimate direct savings for other changes in albedo $(\Delta \mathrm{a})$ multiply the savings by the ratio $\Delta \mathrm{a} / 0.3$.

\begin{tabular}{|c|c|c|c|c|c|c|c|c|c|c|c|c|}
\hline \multirow{3}{*}{$\begin{array}{c}\text { building azimuth } \\
\qquad \& \\
\text { HIR strategy }\end{array}$} & \multicolumn{6}{|c|}{ gas heat } & \multicolumn{6}{|c|}{ electric heat } \\
\hline & \multirow[b]{2}{*}{$\mathrm{R}-7$} & \multicolumn{2}{|l|}{-1979} & \multicolumn{3}{|c|}{$1980+$} & \multicolumn{3}{|c|}{-1979} & \multicolumn{3}{|c|}{$1980+$} \\
\hline & & $\mathrm{R}-11$ & R-19 & R-19 & $R-30$ & R-38 & $\mathrm{R}-7$ & $\mathbf{R}-11$ & $\mathrm{R}-19$ & R-19 & R-30 & $\mathrm{R}-38$ \\
\hline \multicolumn{13}{|l|}{$\phi=0$} \\
\hline base expenditure & 179 & 167 & 155 & 84 & 79 & 76 & 1015 & 1002 & 985 & 444 & 427 & 420 \\
\hline direct shade tree savings & 10 & 10 & 11 & 12 & 13 & 12 & 2 & 2 & 2 & 2 & 1 & 1 \\
\hline direct high albedo savings & 13 & 11 & 10 & 12 & 10 & 9 & 0 & 0 & -1 & 0 & 0 & 0 \\
\hline direct combined savings & 22 & 21 & 21 & 21 & 22 & 21 & 1 & 1 & 1 & 1 & 1 & 1 \\
\hline indirect savings & 7 & 7 & 6 & 7 & 8 & 5 & 2 & 2 & 2 & 1 & 1 & 1 \\
\hline direct $\&$ indirect savings & 27 & 27 & 26 & 27 & 27 & 26 & 1 & 1 & 1 & 2 & 1 & 1 \\
\hline \multicolumn{13}{|l|}{$\phi=90$} \\
\hline base expenditure & 196 & 184 & 173 & 95 & 90 & 88 & 1086 & 1070 & 1050 & 478 & 460 & 453 \\
\hline direct shade tree savings & 13 & 14 & 15 & 18 & 18 & 18 & 6 & 5 & 5 & 4 & 4 & 4 \\
\hline direct high albedo savings & 11 & 10 & 9 & 11 & 9 & 8 & 0 & -1 & -1 & 0 & 0 & 0 \\
\hline direct combined savings & 24 & 23 & 24 & 26 & 26 & 26 & 5 & 5 & 4 & 4 & 3 & 3 \\
\hline indirect savings & 7 & 7 & 6 & 6 & 7 & 7 & 1 & 1 & 1 & 0 & 0 & 0 \\
\hline direct \& indirect savings & 29 & 28 & 28 & 32 & 31 & 31 & 6 & 6 & 5 & 5 & 4 & 4 \\
\hline$\phi=180$ & & & & & & & & & & & & \\
\hline base expenditure & 180 & 168 & 157 & 85 & 79 & 77 & 1033 & 1022 & 1007 & 461 & 444 & 437 \\
\hline direct shade tree savings & 9 & 9 & 10 & 12 & 11 & 12 & 2 & 2 & 2 & 2 & 1 & 1 \\
\hline direct high albedo savings & 12 & 11 & 10 & 12 & 9 & 9 & 0 & -1 & -1 & 0 & -1 & -1 \\
\hline direct combined savings & 20 & 20 & 20 & 21 & 20 & 19 & 1 & 1 & 1 & 2 & 1 & 0 \\
\hline indirect savings & 6 & 6 & 6 & 7 & 6 & 6 & 3 & 2 & 2 & 1 & 1 & 1 \\
\hline direct \& indirect savings & 26 & 26 & 25 & 26 & 25 & 26 & 2 & 2 & 1 & 2 & 2 & 1 \\
\hline \multicolumn{13}{|l|}{$\phi=270$} \\
\hline base expenditure & 197 & 186 & 175 & 95 & 90 & 89 & 1050 & 1038 & 1022 & 469 & 453 & 447 \\
\hline direct shade tree savings & 13 & 14 & 15 & 17 & 18 & 18 & 3 & 3 & 3 & 3 & 3 & 3 \\
\hline direct high albedo savings & 11 & 11 & 10 & 9 & 9 & 9 & 0 & 0 & -1 & 0 & 0 & 0 \\
\hline direct combined savings & 24 & 24 & 24 & 25 & 24 & 26 & 3 & 2 & 2 & 2 & 2 & 2 \\
\hline indirect savings & 7 & 7 & 7 & 6 & 7 & 8 & 2 & 2 & 1 & 1 & 1 & 1 \\
\hline direct $\&$ indirect savings & 29 & 29 & 29 & 29 & 30 & 30 & 3 & 3 & 2 & 4 & 3 & 3 \\
\hline \multicolumn{13}{|l|}{$\phi=\operatorname{avg}$} \\
\hline base expenditure & 188 & 176 & 165 & 90 & 84 & 82 & 1046 & 1033 & 1016 & 463 & 446 & 439 \\
\hline direct shade tree savings & 11 & 12 & 13 & 15 & 15 & 15 & 3 & 3 & 3 & 3 & 2 & 2 \\
\hline direct high albedo savings & 12 & 11 & 10 & 11 & 9 & 9 & 0 & -1 & -1 & 0 & 0 & 0 \\
\hline direct combined savings & 22 & 22 & 22 & 24 & 23 & 23 & 3 & 2 & 2 & 2 & 2 & 2 \\
\hline indirect savings & 7 & 7 & 6 & 7 & 7 & 7 & 2 & 2 & 2 & 1 & 1 & 1 \\
\hline direct \& indirect savings & 28 & 28 & 27 & 29 & 28 & 28 & 3 & 3 & 2 & 3 & 3 & 2 \\
\hline
\end{tabular}


Table A.3.a(iii). Salt Lake City simulated heating annual natural gas expenditures $\left[\$ / 1000 \mathrm{ft}^{2}\right]$, the direct savings [\%] from the strategic placement of shade trees and the use of high-albedo roofs, and the indirect savings [\%] from Heat Island Reduction (HIR) strategies for residential buildings. Base natural gas expenditure is calculated for buildings without shade trees and with a dark roof (albedo 0.2). Direct savings are determined for buildings with 8 shade trees and a high-albedo roof (albedo 0.5). To estimate direct savings for other changes in albedo $(\Delta \mathrm{a})$ multiply the savings by the ratio $\Delta \mathrm{a} / 0.3$.

\begin{tabular}{|c|c|c|c|c|c|c|}
\hline \multirow{3}{*}{$\begin{array}{c}\text { building azimuth } \\
\& \\
\text { HIR strategy }\end{array}$} & \multicolumn{6}{|c|}{ gas heat } \\
\hline & \multicolumn{3}{|c|}{-1979} & \multicolumn{3}{|c|}{$1980+$} \\
\hline & $\mathrm{R}-7$ & $\mathrm{R}-11$ & R-19 & R-19 & $\mathrm{R}-30$ & $\mathrm{R}-38$ \\
\hline \multicolumn{7}{|l|}{$\phi=0$} \\
\hline base expenditure & 457 & 430 & 405 & 193 & 181 & 176 \\
\hline direct shade tree savings & -5 & -5 & -6 & -5 & -6 & -6 \\
\hline direct high albedo savings & -3 & -3 & -2 & -2 & -2 & -2 \\
\hline direct combined savings & -8 & -8 & -8 & -8 & -8 & -8 \\
\hline indirect savings & -3 & -3 & -3 & -3 & -3 & -3 \\
\hline direct \& indirect savings & -9 & -10 & -10 & -11 & -12 & -11 \\
\hline \multicolumn{7}{|l|}{$\phi=90$} \\
\hline base expenditure & 448 & 422 & 397 & 193 & 182 & 177 \\
\hline direct shade tree savings & -9 & -9 & -10 & -9 & -9 & -10 \\
\hline direct high albedo savings & -3 & -3 & -2 & -2 & -2 & -2 \\
\hline direct combined savings & -12 & -13 & -13 & -12 & -12 & -12 \\
\hline indirect savings & -2 & -3 & -3 & -2 & -2 & -2 \\
\hline direct \& indirect savings & -15 & -16 & -16 & -15 & -15 & -16 \\
\hline \multicolumn{7}{|l|}{$\phi=180$} \\
\hline base expenditure & 475 & 448 & 423 & 204 & 192 & 188 \\
\hline direct shade tree savings & -4 & -5 & -5 & -4 & -5 & -5 \\
\hline direct high albedo savings & -3 & -2 & -2 & -2 & -3 & -2 \\
\hline direct combined savings & -7 & -8 & -7 & -7 & -8 & -7 \\
\hline indirect savings & -3 & -3 & -3 & -3 & -3 & -3 \\
\hline direct $\&$ indirect savings & -9 & -10 & -10 & -11 & -11 & -11 \\
\hline \multicolumn{7}{|l|}{$\phi=270$} \\
\hline base expenditure & 461 & 435 & 409 & 197 & 186 & 181 \\
\hline direct shade tree savings & -7 & -7 & -7 & -7 & -7 & -7 \\
\hline direct high albedo savings & -3 & -2 & -2 & -3 & -2 & -2 \\
\hline direct combined savings & -10 & -10 & -10 & -10 & -9 & -9 \\
\hline indirect savings & -2 & -2 & -3 & -3 & -2 & -2 \\
\hline direct \& indirect savings & -11 & -12 & -13 & -13 & -13 & -13 \\
\hline \multicolumn{7}{|l|}{$\phi=$ avg } \\
\hline base expenditure & 460 & 434 & 409 & 197 & 186 & 180 \\
\hline direct shade tree savings & -6 & -7 & -7 & -6 & -6 & -7 \\
\hline direct high albedo savings & -3 & -2 & -2 & -2 & -3 & -2 \\
\hline direct combined savings & -9 & -9 & -9 & -9 & -9 & -9 \\
\hline indirect savings & -3 & -3 & -3 & -3 & -2 & -2 \\
\hline direct \& indirect savings & -11 & -11 & -12 & -13 & -11 & -13 \\
\hline
\end{tabular}


Table A.3.a(iv). Salt Lake City simulated cooling peak power demand [kW/1000ft $\left.{ }^{2}\right]$, the direct savings [\%] from the strategic placement of shade trees and the use of high-albedo roofs, and the indirect savings [\%] from Heat Island Reduction (HIR) strategies for residential buildings. Base peak demand is calculated for buildings without shade trees and with a dark roof (albedo 0.2). Direct savings are determined for buildings with 8 shade trees and a high-albedo roof (albedo 0.5). To estimate direct savings for other changes in albedo $(\Delta a)$ multiply the savings by the ratio $\Delta a / 0.3$.

\begin{tabular}{|c|c|c|c|c|c|c|}
\hline \multirow{3}{*}{$\begin{array}{c}\text { building azimuth } \\
\text { \& } \\
\text { HIR strategy }\end{array}$} & \multicolumn{6}{|c|}{ gas heat } \\
\hline & \multicolumn{3}{|c|}{-1979} & \multicolumn{3}{|c|}{$1980+$} \\
\hline & R-7 & R-11 & R-19 & $\mathrm{R}-19$ & $\mathrm{R}-30$ & R-38 \\
\hline \multicolumn{7}{|l|}{$\phi=0$} \\
\hline base expenditure & 3.42 & 3.40 & 3.38 & 1.84 & 1.82 & 1.81 \\
\hline direct shade tree savings & 4 & 4 & 4 & 5 & 5 & 5 \\
\hline direct high albedo savings & 9 & 8 & 8 & 7 & 7 & 6 \\
\hline direct combined savings & 12 & 12 & 12 & 12 & 12 & 11 \\
\hline indirect savings & 6 & 5 & 5 & 5 & 5 & 5 \\
\hline direct $\&$ indirect savings & 15 & 14 & 14 & 16 & 16 & 16 \\
\hline \multicolumn{7}{|l|}{$\phi=90$} \\
\hline base expenditure & 3.74 & 3.72 & 3.69 & 2.04 & 2.03 & 2.03 \\
\hline direct shade tree savings & 11 & 11 & 11 & 13 & 13 & 13 \\
\hline direct high albedo savings & 8 & 8 & 7 & 6 & 6 & 5 \\
\hline direct combined savings & 19 & 18 & 18 & 19 & 19 & 19 \\
\hline indirect savings & 5 & 5 & 4 & 4 & 4 & 4 \\
\hline direct $\&$ indirect savings & 22 & 22 & 22 & 23 & 23 & 23 \\
\hline \multicolumn{7}{|l|}{$\phi=180$} \\
\hline base expenditure & 3.43 & 3.40 & 3.38 & 1.83 & 1.82 & 1.81 \\
\hline direct shade tree savings & 4 & 5 & 4 & 5 & 5 & 5 \\
\hline direct high albedo savings & 9 & 8 & 8 & 7 & 6 & 6 \\
\hline direct combined savings & 13 & 13 & 12 & 12 & 11 & 11 \\
\hline indirect savings & 6 & 6 & 5 & 5 & 5 & 5 \\
\hline direct $\&$ indirect savings & 15 & 15 & 15 & 16 & 16 & 16 \\
\hline \multicolumn{7}{|l|}{$\phi=270$} \\
\hline base expenditure & 3.55 & 3.51 & 3.49 & 1.90 & 1.88 & 1.88 \\
\hline direct shade tree savings & 7 & 6 & 6 & 7 & 7 & 7 \\
\hline direct high albedo savings & 9 & 8 & 8 & 7 & 6 & 6 \\
\hline direct combined savings & 15 & 14 & 14 & 14 & 13 & 13 \\
\hline indirect savings & 6 & 5 & 5 & 4 & 4 & 4 \\
\hline direct $\&$ indirect savings & 17 & 17 & 17 & 18 & 18 & 18 \\
\hline \multicolumn{7}{|l|}{$\phi=$ avg } \\
\hline base expenditure & 3.54 & 3.51 & 3.48 & 1.90 & 1.89 & 1.88 \\
\hline direct shade tree savings & 6 & 7 & 7 & 8 & 8 & 8 \\
\hline direct high albedo savings & 9 & 8 & 8 & 7 & 6 & 6 \\
\hline direct combined savings & 15 & 14 & 14 & 14 & 14 & 14 \\
\hline indirect savings & 5 & 4 & 5 & 5 & 4 & 4 \\
\hline direct $\&$ indirect savings & 17 & 19 & 17 & 19 & 18 & 18 \\
\hline
\end{tabular}


Table A.3.b(i). Salt Lake City simulated cooling and heating annual total energy expenditures $\left[\$ / 1000 \mathrm{ft}^{2}\right]$, the direct savings [\%] from the strategic placement of shade trees and the use of high-albedo roofs, and the indirect savings [\%] from Heat Island Reduction (HIR) strategies for office buildings. Base energy expenditure is calculated for buildings without shade trees and with a dark roof (albedo 0.2). Direct savings are determined for buildings with 8 shade trees and a high-albedo roof (albedo 0.6). To estimate direct savings for other changes in albedo $(\Delta \mathrm{a})$ multiply the savings by the ratio $\Delta \mathrm{a} / 0.4$.

\begin{tabular}{|c|c|c|c|c|c|c|c|c|c|c|c|c|}
\hline \multirow{3}{*}{$\begin{array}{l}\text { building azimuth } \\
\qquad \& \\
\text { HIR strategy }\end{array}$} & \multicolumn{6}{|c|}{ gas heat } & \multicolumn{6}{|c|}{ electric heat } \\
\hline & \multirow[b]{2}{*}{$\mathrm{R}-7$} & \multicolumn{2}{|l|}{-1979} & \multicolumn{3}{|c|}{$1980+$} & \multicolumn{3}{|c|}{-1979} & \multicolumn{3}{|c|}{$1980+$} \\
\hline & & $\mathrm{R}-11$ & $\mathrm{R}-19$ & R-19 & $\mathrm{R}-30$ & R-38 & $\mathrm{R}-7$ & $\mathrm{R}-11$ & $\mathrm{R}-19$ & $\mathrm{R}-19$ & $\mathrm{R}-30$ & $\mathrm{R}-38$ \\
\hline$\phi=0$ & & & & & & & & & & & & \\
\hline base expenditure & 641 & 623 & 606 & 308 & 301 & 298 & 761 & 736 & 712 & 348 & 339 & 334 \\
\hline direct shade tree savings & 5 & 5 & 5 & 5 & 5 & 5 & 4 & 4 & 4 & 4 & 4 & 4 \\
\hline direct high albedo savings & 6 & 5 & 4 & 4 & 3 & 3 & 4 & 4 & 3 & 3 & 2 & 2 \\
\hline direct combined savings & 11 & 9 & 8 & 8 & 7 & 7 & 9 & 8 & 6 & 6 & 6 & 6 \\
\hline indirect savings & 3 & 3 & 3 & 3 & 3 & 3 & 2 & 2 & 3 & 3 & 3 & 3 \\
\hline direct $\&$ indirect savings & 14 & 13 & 11 & 11 & 11 & 10 & 11 & 10 & 9 & 9 & 9 & 8 \\
\hline$\phi=90$ & & & & & & & & & & & & \\
\hline base expenditure & 670 & 652 & 636 & 324 & 316 & 313 & 801 & 776 & 754 & 368 & 357 & 353 \\
\hline direct shade tree savings & 9 & 10 & 10 & 10 & 10 & 11 & 8 & 9 & 9 & 8 & 9 & 9 \\
\hline direct high albedo savings & 5 & 4 & 3 & 3 & 2 & 2 & 4 & 3 & 2 & 2 & 2 & 2 \\
\hline direct combined savings & 14 & 14 & 13 & 13 & 13 & 12 & 12 & 11 & 11 & 11 & 10 & 10 \\
\hline indirect savings & 3 & 3 & 3 & 3 & 3 & 4 & 2 & 2 & 3 & 2 & 3 & 3 \\
\hline direct $\&$ indirect savings & 17 & 17 & 16 & 16 & 16 & 16 & 14 & 14 & 14 & 13 & 13 & 13 \\
\hline$\phi=\mathbf{a v g}$ & & & & & & & & & & & & \\
\hline base expenditure & 656 & 638 & 621 & 316 & 308 & 306 & 781 & 756 & 733 & 358 & 348 & 344 \\
\hline direct shade tree savings & 7 & 7 & 7 & 7 & 8 & 8 & 6 & 6 & 7 & 6 & 6 & 7 \\
\hline direct high albedo savings & 6 & 5 & 3 & 3 & 2 & 2 & 4 & 3 & 3 & 2 & 2 & 2 \\
\hline direct combined savings & 13 & 12 & 11 & 10 & 10 & 10 & 10 & 10 & 9 & 9 & 8 & 8 \\
\hline indirect savings & 3 & 3 & 3 & 3 & 3 & 3 & 2 & 2 & 3 & 3 & 3 & 3 \\
\hline direct $\&$ indirect savings & 16 & 15 & 14 & 14 & 13 & 13 & 12 & 12 & 11 & 11 & 11 & 10 \\
\hline
\end{tabular}


Table A.3.b(ii). Salt Lake City simulated cooling and heating annual electricity expenditures $\left[\$ / 1000 \mathrm{ft}^{2}\right]$, the direct savings [\%] from the strategic placement of shade trees and the use of high-albedo roofs, and the indirect savings [\%] from Heat Island Reduction (HIR) strategies for office buildings. Base electricity expenditure is calculated for buildings without shade trees and with a dark roof (albedo 0.2). Direct savings are determined for buildings with 8 shade trees and a high-albedo roof (albedo 0.6). To estimate direct savings for other changes in albedo $(\Delta \mathrm{a})$ multiply the savings by the ratio $\Delta \mathrm{a} / 0.4$.

\begin{tabular}{|c|c|c|c|c|c|c|c|c|c|c|c|c|}
\hline \multirow{3}{*}{$\begin{array}{c}\text { building azimuth } \\
\& \\
\text { HIR strategy }\end{array}$} & \multicolumn{6}{|c|}{ gas heat } & \multicolumn{6}{|c|}{ electric heat } \\
\hline & \multicolumn{3}{|c|}{-1979} & \multicolumn{3}{|c|}{$1980+$} & \multicolumn{3}{|c|}{-1979} & \multicolumn{3}{|c|}{$1980+$} \\
\hline & R-7 & R-11 & R-19 & R-19 & R-30 & $\mathrm{R}-38$ & R-7 & R-11 & $\mathrm{R}-19$ & $\mathrm{R}-19$ & R-30 & R-38 \\
\hline \multicolumn{13}{|l|}{$\phi=0$} \\
\hline base expenditure & 494 & 485 & 477 & 253 & 249 & 247 & 761 & 736 & 712 & 348 & 339 & 334 \\
\hline direct shade tree savings & 7 & 7 & 7 & 6 & 6 & 6 & 4 & 4 & 4 & 4 & 4 & 4 \\
\hline direct high albedo savings & 9 & 7 & 5 & 6 & 4 & 4 & 4 & 4 & 3 & 3 & 2 & 2 \\
\hline direct combined savings & 16 & 14 & 12 & 12 & 10 & 10 & 9 & 8 & 6 & 6 & 6 & 6 \\
\hline indirect savings & 4 & 4 & 4 & 5 & 4 & 4 & 2 & 2 & 3 & 3 & 3 & 3 \\
\hline direct $\&$ indirect savings & 20 & 18 & 16 & 16 & 15 & 14 & 11 & 10 & 9 & 9 & 9 & 8 \\
\hline \multicolumn{13}{|l|}{$\phi=90$} \\
\hline base expenditure & 511 & 502 & 494 & 263 & 259 & 257 & 801 & 776 & 754 & 368 & 357 & 353 \\
\hline direct shade tree savings & 12 & 12 & 13 & 13 & 14 & 13 & 8 & 9 & 9 & 8 & 9 & 9 \\
\hline direct high albedo savings & 8 & 7 & 5 & 5 & 4 & 4 & 4 & 3 & 2 & 2 & 2 & 2 \\
\hline direct combined savings & 20 & 19 & 17 & 18 & 17 & 17 & 12 & 11 & 11 & 11 & 10 & 10 \\
\hline indirect savings & 4 & 4 & 4 & 5 & 5 & 5 & 2 & 2 & 3 & 2 & 3 & 3 \\
\hline direct \& indirect savings & 24 & 23 & 21 & 22 & 22 & 21 & 14 & 14 & 14 & 13 & 13 & 13 \\
\hline \multicolumn{13}{|l|}{$\phi=\mathbf{a v g}$} \\
\hline base expenditure & 502 & 494 & 486 & 258 & 254 & 252 & 781 & 756 & 733 & 358 & 348 & 344 \\
\hline direct shade tree savings & 9 & 10 & 10 & 10 & 10 & 10 & 6 & 6 & 7 & 6 & 6 & 7 \\
\hline direct high albedo savings & 9 & 7 & 5 & 5 & 4 & 4 & 4 & 3 & 3 & 2 & 2 & 2 \\
\hline direct combined savings & 18 & 16 & 15 & 15 & 14. & 13 & 10 & 10 & 9 & 9 & 8 & 8 \\
\hline indirect savings & 4 & 4 & 4 & 5 & 5 & 5 & 2 & 2 & 3 & 3 & 3 & 3 \\
\hline direct $\&$ indirect savings & 22 & 20 & 19 & 19 & 18 & 18 & 12 & 12 & 11 & 11 & 11 & 10 \\
\hline
\end{tabular}


Table A.3.b(iii). Salt Lake City simulated heating annual natural gas expenditures $\left[\$ / 1000 \mathrm{ft}^{2}\right]$, the direct savings [\%] from the strategic placement of shade trees and the use of high-albedo roofs, and the indirect savings [\%] from Heat Island Reduction (HIR) strategies for office buildings. Base natural gas expenditure is calculated for buildings without shade trees and with a dark roof (albedo 0.2). Direct savings are determined for buildings with 8 shade trees and a high-albedo roof (albedo 0.6). To estimate direct savings for other changes in albedo $(\Delta \mathrm{a})$ multiply the savings by the ratio $\Delta \mathrm{a} / 0.4$.

\begin{tabular}{|l||rrrrrr|}
\hline \multicolumn{1}{|c|}{$\begin{array}{c}\text { building azimuth } \\
\text { HIR strategy }\end{array}$} & R-7 & $\begin{array}{c}\text { gas heat } \\
\text { R-11 }\end{array}$ & R-19 & R-19 & R-30 & R-38 \\
\hline \hline $\begin{array}{l}\phi=0 \\
\text { base expenditure }\end{array}$ & 147 & 138 & 129 & 56 & 52 & 50 \\
direct shade tree savings & -1 & -1 & -2 & -2 & -2 & -4 \\
direct high albedo savings & -5 & -4 & -3 & -5 & -4 & -4 \\
direct combined savings & -6 & -5 & -5 & -7 & -8 & -8 \\
indirect savings & -1 & -1 & -2 & -2 & -2 & -4 \\
direct \& indirect savings & -7 & -7 & -6 & -11 & -10 & -10 \\
$\phi=90$ & & & & & & \\
base expenditure & 159 & 150 & 141 & 61 & 57 & 56 \\
direct shade tree savings & 1 & 1 & 1 & -3 & -4 & -2 \\
direct high albedo savings & -4 & -3 & -3 & -7 & -5 & -4 \\
direct combined savings & -4 & -3 & -2 & -8 & -7 & -7 \\
indirect savings & -1 & -1 & -1 & -2 & -2 & -2 \\
direct \& indirect savings & -4 & -3 & -3 & -11 & -11 & -9 \\
$\phi=$ avg & & & & & & \\
base expenditure & 153 & 144 & 135 & 58 & 54 & 53 \\
direct shade tree savings & 0 & 0 & 0 & -3 & -3 & -3 \\
direct high albedo savings & -4 & -3 & -3 & -6 & -6 & -4 \\
direct combined savings & -5 & -4 & -3 & -8 & -7 & -8 \\
indirect savings & -1 & -1 & -1 & -2 & -2 & -3 \\
direct \& indirect savings & -6 & -5 & -4 & -11 & -10 & -9 \\
\hline
\end{tabular}


Table A.3.b(iv). Salt Lake City simulated cooling peak power demand $\left[\mathrm{kW} / 1000 \mathrm{ft}^{2}\right]$, the direct savings [\%] from the strategic placement of shade trees and the use of high-albedo roofs, and the indirect savings [\%] from Heat Island Reduction (HIR) strategies for office buildings. Base peak demand is calculated for buildings without shade trees and with a dark roof (albedo 0.2). Direct savings are determined for buildings with 8 shade trees and a high-albedo roof (albedo 0.6). To estimate direct savings for other changes in albedo $(\Delta \mathrm{a})$ multiply the savings by the ratio $\Delta \mathrm{a} / 0.4$.

\begin{tabular}{|l||cccccc|}
\hline \multicolumn{1}{|c||}{$\begin{array}{c}\text { building azimuth } \\
\text { \& }\end{array}$} & \multicolumn{5}{c}{ gas heat } \\
\multicolumn{1}{|c}{ HIR strategy } & R-7 & R-11 & R-19 & R-19 & R-30 & R-38 \\
\hline \hline $\begin{array}{l}\phi=0 \\
\text { base expenditure }\end{array}$ & 7.38 & 7.14 & 6.91 & 4.00 & 3.91 & 3.87 \\
direct shade tree savings & 5 & 4 & 4 & 5 & 5 & 5 \\
direct high albedo savings & 6 & 5 & 4 & 5 & 4 & 3 \\
direct combined savings & 10 & 9 & 7 & 9 & 8 & 8 \\
indirect savings & 5 & 5 & 5 & 5 & 5 & 5 \\
direct \& indirect savings & 15 & 13 & 12 & 14 & 13 & 13 \\
$\phi=90$ & & & & & & \\
base expenditure & 7.74 & 7.51 & 7.30 & 4.22 & 4.13 & 4.09 \\
direct shade tree savings & 9 & 10 & 10 & 12 & 13 & 13 \\
direct high albedo savings & 6 & 5 & 3 & 4 & 3 & 3 \\
direct combined savings & 15 & 14 & 13 & 16 & 16 & 16 \\
indirect savings & 5 & 5 & 5 & 5 & 5 & 5 \\
direct \& indirect savings & 20 & 19 & 18 & 21 & 20 & 20 \\
$\phi=$ avg & & & & & & \\
base expenditure & 7.56 & 7.32 & 7.10 & 4.11 & 4.02 & 3.98 \\
direct shade tree savings & 7 & 7 & 7 & 8 & 9 & 9 \\
direct high albedo savings & 6 & 5 & 4 & 5 & 3 & 3 \\
direct combined savings & 13 & 11 & 10 & 13 & 12 & 12 \\
indirect savings & 5 & 5 & 5 & 5 & 5 & 5 \\
direct \& indirect savings & 17 & 16 & 15 & 17 & 17 & 16 \\
\hline
\end{tabular}


Table A.3.c(i). Salt Lake City simulated cooling and heating annual total energy expenditures $\left[\$ / 1000 \mathrm{ft}^{2}\right]$, the direct savings [\%] from the strategic placement of shade trees and the use of high-albedo roofs, and the indirect savings [\%] from Heat Island Reduction (HIR) strategies for retail buildings. Base energy expenditure is calculated for buildings without shade trees and with a dark roof (albedo 0.2). Direct savings are determined for buildings with 4 shade trees and a high-albedo roof (albedo 0.6). To estimate direct savings for other changes in albedo $(\Delta \mathrm{a})$ multiply the savings by the ratio $\Delta \mathrm{a} / 0.4$.

\begin{tabular}{|c|c|c|c|c|c|c|c|c|c|c|c|c|}
\hline \multirow{3}{*}{$\begin{array}{c}\text { building azimuth } \\
\text { \& } \\
\text { HIR strategy }\end{array}$} & \multicolumn{6}{|c|}{ gas heat } & \multicolumn{6}{|c|}{ electric heat } \\
\hline & \multicolumn{3}{|c|}{-1979} & \multicolumn{3}{|c|}{$1980+$} & \multicolumn{3}{|c|}{-1979} & \multicolumn{3}{|c|}{$1980+$} \\
\hline & R-7 & $\mathrm{R}-11$ & R-19 & $\mathrm{R}-19$ & R-30 & R-38 & R-7 & R-11 & $\mathrm{R}-19$ & $\mathrm{R}-19$ & $\mathrm{R}-30$ & $\mathrm{R}-38$ \\
\hline \multicolumn{13}{|l|}{$\phi=0$} \\
\hline base expenditure & 598 & 580 & 571 & 234 & 231 & 229 & 635 & 606 & 591 & 236 & 232 & 230 \\
\hline direct shade tree savings & 2 & 3 & 4 & 5 & 6 & 6 & 2 & 2 & 3 & 5 & 6 & 6 \\
\hline direct high albedo savings & 11 & 8 & 6 & 7 & 6 & 5 & 10 & 7 & 6 & 7 & 6 & 5 \\
\hline direct combined savings & 14 & 12 & 10 & 12 & 11 & 11 & 13 & 11 & 9 & 12 & 11 & 11 \\
\hline indirect savings & 3 & 3 & 3 & 4 & 4 & 4 & 3 & 3 & 3 & 4 & 4 & 4 \\
\hline direct \& indirect savings & 17 & 15 & 13 & 16 & 15 & 14 & 15 & 13 & 12 & 15 & 15 & 14 \\
\hline \multicolumn{13}{|l|}{$\phi=90$} \\
\hline base expenditure & 647 & 629 & 613 & 260 & 252 & 250 & 698 & 670 & 645 & 263 & 255 & 252 \\
\hline direct shade tree savings & 9 & 9 & 10 & 11 & 11 & 12 & 8 & 9 & 10 & 11 & 11 & 12 \\
\hline direct high albedo savings & 10 & 8 & 6 & 7 & 6 & 6 & 8 & 7 & 6 & 6 & 6 & 5 \\
\hline direct combined savings & 19 & 18 & 16 & 18 & 17 & 17 & 17 & 17 & 16 & 17 & 17 & 17 \\
\hline indirect savings & 3 & 3 & 2 & 4 & 4 & 4 & 2 & 2 & 2 & 3 & 4 & 4 \\
\hline direct $\&$ indirect savings & 21 & 20 & 19 & 22 & 20 & 20 & 19 & 19 & 18 & 21 & 20 & 20 \\
\hline$\phi=270$ & & & & & & & & & & & & \\
\hline base expenditure & 613 & 592 & 576 & 246 & 239 & 237 & 661 & 630 & 606 & 250 & 242 & 239 \\
\hline direct shade tree savings & 7 & 7 & 8 & 9 & 9 & 10 & 6 & 7 & 8 & 9 & 10 & 10 \\
\hline direct high albedo savings & 10 & 8 & 6 & 7 & 5 & 5 & 8 & 7 & 5 & 6 & 5 & 5 \\
\hline direct combined savings & 17 & 15 & 14 & 16 & 15 & 15 & 15 & 14 & 13 & 15 & 14 & 14 \\
\hline indirect savings & 3 & 3 & 3 & 4 & 4 & 4 & 3 & 3 & 3 & 4 & 4 & 4 \\
\hline direct \& indirect savings & 20 & 18 & 17 & 20 & 18 & 19 & 18 & 17 & 16 & 19 & 18 & 18 \\
\hline \multicolumn{13}{|l|}{$\phi=\operatorname{avg}$} \\
\hline base expenditure & 619 & 600 & 587 & 247 & 241 & 239 & 665 & 635 & 614 & 250 & 243 & 240 \\
\hline direct shade tree savings & 6 & 6 & 7 & 8 & 9 & 9 & 6 & 6 & 7 & 8 & 9 & 9 \\
\hline direct high albedo savings & 10 & 8 & 6 & 7 & 6 & 5 & 9 & 7 & 6 & 7 & 6 & 5 \\
\hline direct combined savings & 17 & 15 & 13 & 16 & 14 & 14 & 15 & 14 & 13 & 15 & 14 & 14 \\
\hline indirect savings & 3 & 3 & 3 & 4 & 4 & 4 & 2 & 2 & 3 & 4 & 4 & 4 \\
\hline direct \& indirect savings & 19 & 18 & 16 & 19 & 18 & 18 & 18 & 16 & 15 & 18 & 18 & 17 \\
\hline
\end{tabular}


Table A.3.c(ii). Salt Lake City simulated cooling and heating annual electricity expenditures $\left[\$ / 1000 \mathrm{ft}^{2}\right]$, the direct savings [\%] from the strategic placement of shade trees and the use of high-albedo roofs, and the indirect savings [\%] from Heat Island Reduction (HIR) strategies for retail buildings. Base electricity expenditure is calculated for buildings without shade trees and with a dark roof (albedo 0.2 ). Direct savings are determined for buildings with 4 shade trees and a high-albedo roof (albedo 0.6 ). To estimate direct savings for other changes in albedo $(\Delta \mathrm{a})$ multiply the savings by the ratio $\Delta \mathrm{a} / 0.4$.

\begin{tabular}{|c|c|c|c|c|c|c|c|c|c|c|c|c|}
\hline \multirow{3}{*}{$\begin{array}{c}\text { building azimuth } \\
\& \\
\text { HIR strategy }\end{array}$} & \multicolumn{6}{|c|}{ gas heat } & \multicolumn{6}{|c|}{ electric heat } \\
\hline & \multicolumn{3}{|c|}{-1979} & \multicolumn{3}{|c|}{$1980+$} & \multicolumn{3}{|c|}{-1979} & \multicolumn{3}{|c|}{$1980+$} \\
\hline & R-7 & $\mathrm{R}-11$ & R-19 & $\mathrm{R}-19$ & R-30 & $\mathrm{R}-38$ & R-7 & $\mathrm{R}-11$ & R-19 & R-19 & $\mathrm{R}-30$ & $R-38$ \\
\hline$\phi=0$ & & & & & & & & & & & & \\
\hline base expenditure & 559 & 551 & 550 & 232 & 230 & 228 & 635 & 606 & 591 & 236 & 232 & 230 \\
\hline direct shade tree savings & 3 & 3 & 4 & 5 & 6 & 6 & 2 & 2 & 3 & 5 & 6 & 6 \\
\hline direct high albedo savings & 12 & 9 & 6 & 7 & 6 & 5 & 10 & 7 & 6 & 7 & 6 & 5 \\
\hline direct combined savings & 16 & 13 & 11 & 12 & 12 & 11 & 13 & 11 & 9 & 12 & 11 & 11 \\
\hline indirect savings & 3 & 3 & 3 & 4 & 4 & 4 & 3 & 3 & 3 & 4 & 4 & 4 \\
\hline direct \& indirect savings & 19 & 16 & 14 & 16 & 16 & 15 & 15 & 13 & 12 & 15 & 15 & 14 \\
\hline base expenditure & 591 & 585 & 581 & 255 & 250 & 248 & 698 & 670 & 645 & 263 & 255 & 252 \\
\hline direct shade tree savings & 9 & 10 & 11 & 11 & 12 & 12 & 8 & 9 & 10 & 11 & 11 & 12 \\
\hline direct high albedo savings & 11 & 9 & 7 & 8 & 6 & 6 & 8 & 7 & 6 & 6 & 6 & 5 \\
\hline direct combined savings & 21 & 20 & 18 & 19 & 18 & 18 & 17 & 17 & 16 & 17 & 17 & 17 \\
\hline indirect savings & 3 & 3 & 3 & 4 & 4 & 4 & 2 & 2 & 2 & 3 & 4 & 4 \\
\hline direct $\&$ indirect savings & 24 & 22 & 20 & 22 & 21 & 21 & 19 & 19 & 18 & 21 & 20 & 20 \\
\hline$\phi=270$ & & & & & & & & & & & & \\
\hline base expenditure & 561 & 552 & 546 & 242 & 236 & 234 & 661 & 630 & 606 & 250 & 242 & 239 \\
\hline direct shade tree savings & 7 & 8 & 8 & 10 & 9 & 10 & 6 & 7 & 8 & 9 & 10 & 10 \\
\hline direct high albedo savings & 11 & 9 & 6 & 7 & 6 & 5 & 8 & 7 & 5 & 6 & 5 & 5 \\
\hline direct combined savings & 19 & 17 & 15 & 17 & 15 & 15 & 15 & 14 & 13 & 15 & 14 & 14 \\
\hline indirect savings & 3 & 3 & 3 & 5 & 4 & 4 & 3 & 3 & 3 & 4 & 4 & 4 \\
\hline direct \& indirect savings & 23 & 20 & 18 & 21 & 19 & 19 & 18 & 17 & 16 & 19 & 18 & 18 \\
\hline$\phi=$ avg & & & & & & & & & & & & \\
\hline base expenditure & 570 & 563 & 559 & 243 & 239 & 237 & 665 & 635 & 614 & 250 & 243 & 240 \\
\hline direct shade tree savings & 7 & 7 & 8 & 9 & 9 & 9 & 6 & 6 & 7 & 8 & 9 & 9 \\
\hline direct high albedo savings & 12 & 9 & 7 & 8 & 6 & 5 & 9 & 7 & 6 & 7 & 6 & 5 \\
\hline direct combined savings & 19 & 17 & 14 & 16 & 15 & 15 & 15 & 14 & 13 & 15 & 14 & 14 \\
\hline indirect savings & 3 & 3 & 3 & 4 & 4 & 4 & 2 & 2 & 3 & 4 & 4 & 4 \\
\hline direct $\&$ indirect savings & 22 & 20 & 17 & 20 & 19 & 18 & 18 & 16 & 15 & 18 & 18 & 17 \\
\hline
\end{tabular}


Table A.3.c(iii). Salt Lake City simulated heating annual natural gas expenditures $\left[\$ / 1000 \mathrm{ft}^{2}\right]$, the direct savings [\%] from the strategic placement of shade trees and the use of high-albedo roofs, and the indirect savings [\%] from Heat Island Reduction (HIR) strategies for retail buildings. Base natural gas expenditure is calculated for buildings without shade trees and with a dark roof (albedo 0.2). Direct savings are determined for buildings with 4 shade trees and a high-albedo roof (albedo 0.6). To estimate direct savings for other changes in albedo $(\Delta \mathrm{a})$ multiply the savings by the ratio $\Delta \mathrm{a} / 0.4$.

\begin{tabular}{|c|c|c|c|c|c|c|}
\hline \multirow{3}{*}{\begin{tabular}{|c|} 
building azimuth \\
$\&$ \\
HIR strategy
\end{tabular}} & \multicolumn{6}{|c|}{ gas heat } \\
\hline & & -1979 & & & $1980+$ & \\
\hline & R-7 & $\mathrm{R}-11$ & R-19 & R-19 & $\mathrm{R}-30$ & R-38 \\
\hline \multicolumn{7}{|l|}{$\phi=0$} \\
\hline base expenditure & 39 & 29 & 21 & 2 & 1 & 1 \\
\hline direct shade tree savings & -3 & -3 & -5 & 0 & 0 & 0 \\
\hline direct high albedo savings & -8 & -7 & -5 & 0 & 0 & 0 \\
\hline direct combined savings & -10 & -10 & -10 & -50 & 0 & 0 \\
\hline indirect savings & 0 & 0 & 0 & 0 & 0 & 0 \\
\hline direct $\&$ indirect savings & -10 & -10 & -10 & -50 & -100 & 0 \\
\hline \multicolumn{7}{|l|}{$\phi=90$} \\
\hline base expenditure & 56 & 44 & 32 & 5 & 3 & 2 \\
\hline direct shade tree savings & 2 & 2 & 3 & 0 & 0 & 0 \\
\hline direct high albedo savings & -9 & -9 & -6 & -20 & 0 & -50 \\
\hline direct combined savings & -9 & -7 & -6 & -20 & 0 & -50 \\
\hline indirect savings & -2 & 0 & -3 & 0 & 0 & 0 \\
\hline direct \& indirect savings & -9 & -7 & -6 & -20 & 0 & -50 \\
\hline \multicolumn{7}{|l|}{$\phi=270$} \\
\hline base expenditure & 52 & 40 & 30 & 4 & 3 & 2 \\
\hline direct shade tree savings & 0 & -3 & 0 & -25 & 0 & 0 \\
\hline direct high albedo savings & -10 & -10 & -3 & -25 & 0 & -50 \\
\hline direct combined savings & -10 & -10 & -3 & -50 & 0 & -50 \\
\hline indirect savings & -2 & -3 & 0 & -25 & 0 & 0 \\
\hline direct $\&$ indirect savings & -12 & -10 & -7 & -50 & -33 & -50 \\
\hline \multicolumn{7}{|l|}{$\phi=$ avg } \\
\hline base expenditure & 49 & 37 & 28 & 4 & 2 & 2 \\
\hline direct shade tree savings & 0 & -3 & 0 & -9 & 0 & 0 \\
\hline direct high albedo savings & -9 & -24 & -5 & -18 & -50 & -40 \\
\hline direct combined savings & -10 & -24 & -6 & -36 & -50 & -40 \\
\hline indirect savings & -1 & -3 & -1 & -9 & 0 & 0 \\
\hline direct $\&$ indirect savings & -10 & -24 & -7 & -36 & -100 & -40 \\
\hline
\end{tabular}


Table A.3.c(iv). Salt Lake City simulated cooling peak power demand $\left[\mathrm{kW} / 1000 \mathrm{ft}^{2}\right]$, the direct savings [\%] from the strategic placement of shade trees and the use of high-albedo roofs, and the indirect savings [\%] from Heat Island Reduction (HIR) strategies for retail buildings. Base peak demand is calculated for buildings without shade trees and with a dark roof (albedo 0.2). Direct savings are determined for buildings with 4 shade trees and a high-albedo roof (albedo 0.6). To estimate direct savings for other changes in albedo $(\Delta \mathrm{a})$ multiply the savings by the ratio $\Delta \mathrm{a} / 0.4$.

\begin{tabular}{|c|c|c|c|c|c|c|}
\hline \multirow{3}{*}{$\begin{array}{c}\text { building azimuth } \\
\text { \& } \\
\text { HIR strategy }\end{array}$} & \multicolumn{6}{|c|}{ gas heat } \\
\hline & \multicolumn{3}{|c|}{-1979} & \multicolumn{3}{|c|}{$1980+$} \\
\hline & R-7 & $\mathrm{R}-11$ & R-19 & R-19 & $\mathrm{R}-30$ & R-38 \\
\hline \multicolumn{7}{|l|}{$\phi=0$} \\
\hline base expenditure & 4.99 & 4.63 & 4.43 & 2.39 & 2.31 & 2.27 \\
\hline direct shade tree savings & 0 & -2 & 0 & 1 & 2 & 2 \\
\hline direct high albedo savings & 12 & 7 & 5 & 6 & 5 & 4 \\
\hline direct combined savings & 11 & 7 & 6 & 8 & 7 & 6 \\
\hline indirect savings & 3 & 3 & 3 & 3 & 3 & 3 \\
\hline direct \& indirect savings & 14 & 10 & 10 & 12 & 10 & 10 \\
\hline \multicolumn{7}{|l|}{$\phi=90$} \\
\hline base expenditure & 5.69 & 5.46 & 5.23 & 2.85 & 2.74 & 2.70 \\
\hline direct shade tree savings & 8 & 9 & 10 & 11 & 11 & 12 \\
\hline direct high albedo savings & 9 & 7 & 6 & 7 & 5 & 5 \\
\hline direct combined savings & 18 & 17 & 16 & 18 & 17 & 17 \\
\hline indirect savings & 2 & 2 & 2 & 2 & 2 & 2 \\
\hline direct \& indirect savings & 20 & 19 & 18 & 20 & 19 & 19 \\
\hline \multicolumn{7}{|l|}{$\phi=270$} \\
\hline base expenditure & 5.28 & 5.02 & 4.79 & 2.58 & 2.49 & 2.45 \\
\hline direct shade tree savings & 5 & 6 & 6 & 7 & 7 & 7 \\
\hline direct high albedo savings & 9 & 7 & 5 & 6 & 5 & 6 \\
\hline direct combined savings & 15 & 13 & 11 & 13 & 12 & 11 \\
\hline indirect savings & 3 & 3 & 3 & 3 & 3 & 3 \\
\hline direct $\&$ indirect savings & 18 & 16 & 14 & 16 & 15 & 15 \\
\hline \multicolumn{7}{|l|}{$\phi=\mathbf{a v g}$} \\
\hline base expenditure & 5.32 & 5.04 & 4.82 & 2.60 & 2.51 & 2.48 \\
\hline direct shade tree savings & 5 & 5 & 6 & 6 & 7 & 7 \\
\hline direct high albedo savings & 10 & 7 & 5 & 6 & 5 & 5 \\
\hline direct combined savings & 15 & 13 & 11 & 13 & 12 & 12 \\
\hline indirect savings & 3 & 3 & 3 & 3 & 3 & 3 \\
\hline direct \& indirect savings & 18 & 15 & 14 & 16 & 15 & 15 \\
\hline
\end{tabular}

